AEC

RESEARCH

and

DEVELOPMENT

REPORT
BNWL-181

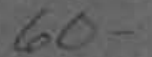

BURIED RADIOACTIVE WASTE STORAGE TANK TEMPERATURES AND SOIL TEMPERATURES NEAR LEAKS

G. JANSEN, Jr.

W. E. WILLINGHAM

W. v. DeMIER

MARCH, 1966

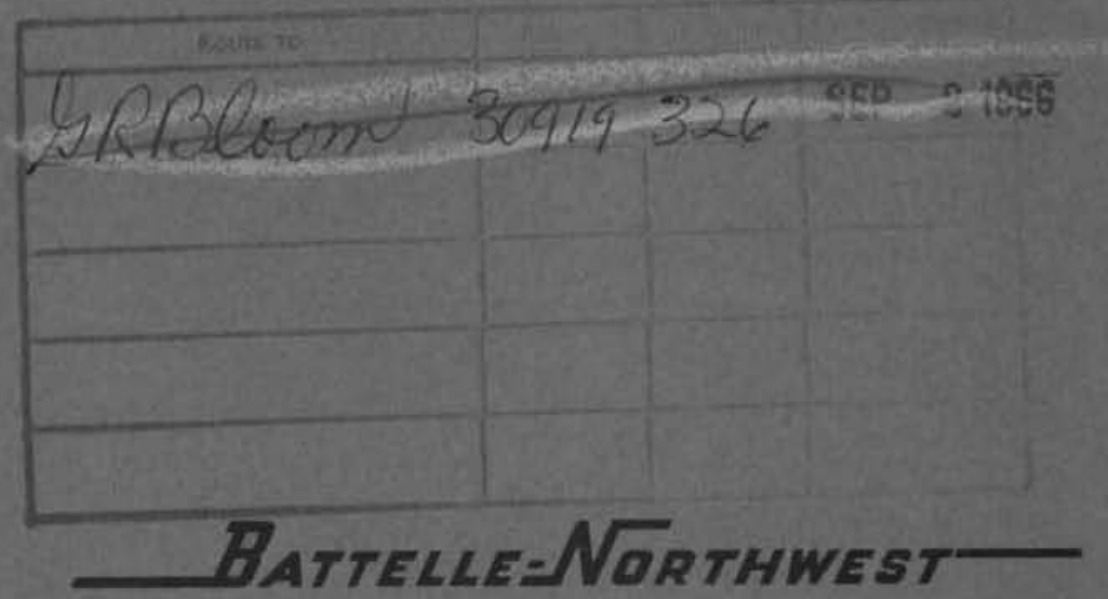

BATIELLE MEMORIAL INSTITUTE / PACIFIC NORTHWEST LABORATORY 


\section{LEGAL NOTICE}

This report was prepared as an account of Government sponsored work. Neither the Unifed States: nor the Commission, nor any person acting on behalf of the Commission

A. Makes any warranty or representation, expressed or implied, with respect to the accuracy, completeness, or usefulness of the information contained in this report, or that the use of any information, apparatus, method, or process disclosed in this report may not infringe privately owned tights; or

B. Assumes any liabilities with respect to the use of, or for damages resulting from the use of any information, apparatus, method, or process disclosed in this report.

As used in the obove. "person acting on behalf of the Commission" includes any employee or contractor of the Commission, of employee of such contractor, to the extent that such employee or contractor of the Commission, or employee of such contractor prepares, disseminates, or provides occess to, any information pursuant to his employment or contract with the Commission, or his employment with such contractor.

PACIFIC NORTHWEST LABORATORY

RICHLAND, WASHINOTON

operated by

BATTELLE MEMORIAL INSTITUTE

for the

UNITED STATES ATOMIC ENERGY COMMISSION UNDER CONTRACT AT(45-1)-1830

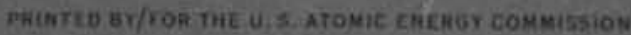


BNWL -181

UC-70, Waste Disposa 1 and Processing

\title{
BURIED RADIOACTIVE WASTE STORAGE TANK TEMPERATURES AND SOIL TEMPERATURES NEAR LEAKS
}

\author{
By \\ G. Jansen, Jr. \\ W. E. Wil1ingham \\ W. V. DeMier \\ Chemistry Department \\ Chemical Development Section
}

March, 1966

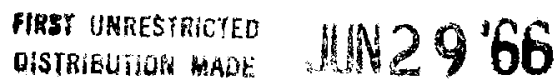

PACIFIC NORTHWEST LABORATORY

RICHLAND, WASHINGTON 
Printed in USA. Price $\$ 3.00$. Available from the Clearinghouse for Federal Scientific and Technical Information, National Bureau of Standards

U.S. Department of Commerce, Springfield, Virginia 


\section{TABLE OF CONTENTS}

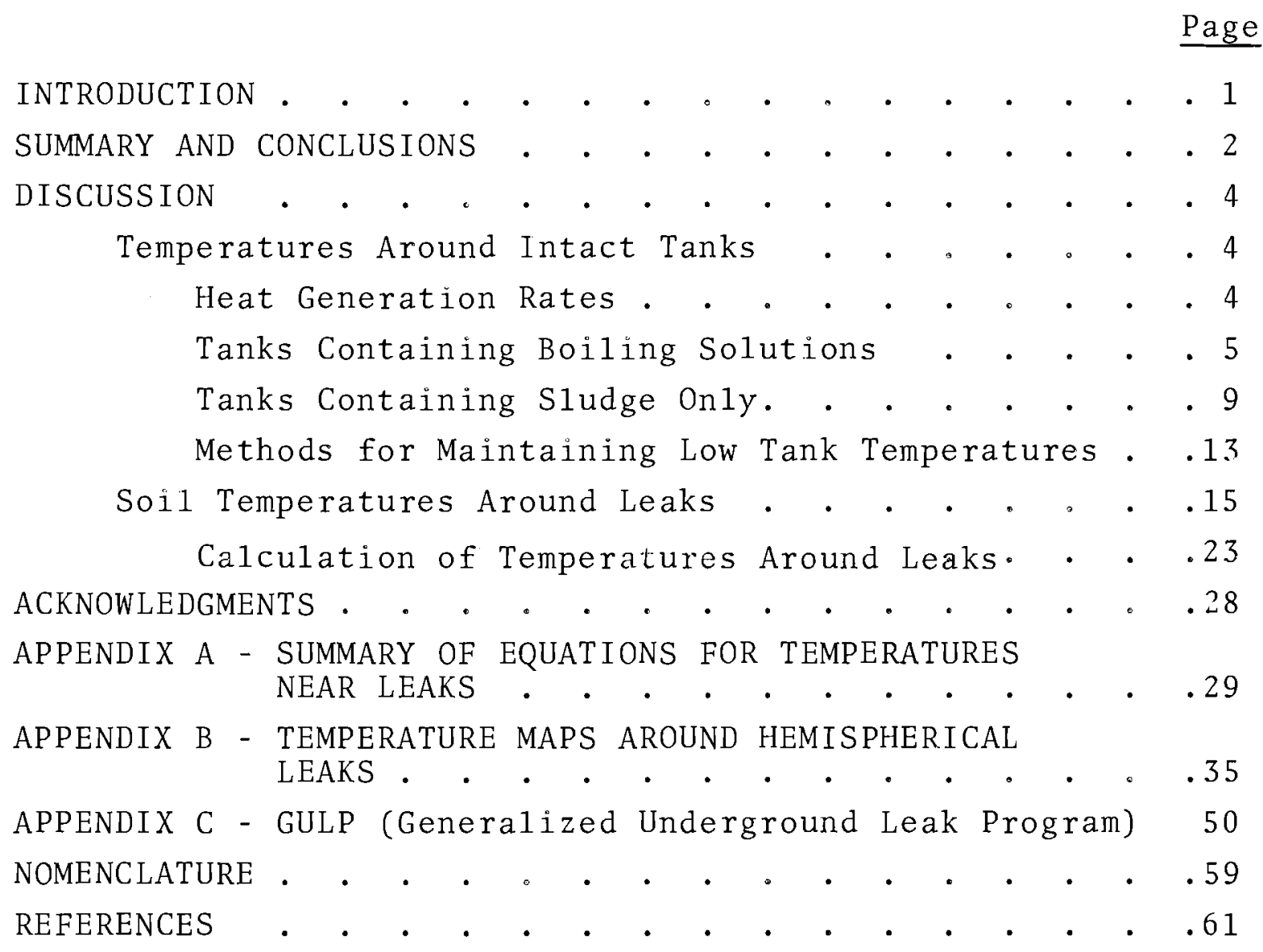


BNWL -181

\author{
BURIED RADIOACTIVE WASTE STORAGE TANK TEMPERATURES \\ AND SOIL TEMPERATURES NEAR LEAKS
}

\title{
INTRODUCTION
}

This report presents an analysis of the temperatures that might be attained as a result of removal of supernatant liquid from a sludge-containing tank and of the temperatures that would occur in the soil because of a leak from the tank.

Large quantities of radioactive waste solutions and sludges are now being stored at United States Atomic Energy Commission production sites and may be stored near commercial fuel processing plants in the future. Storage systems for these wastes are designed to assure means of radiolytic heat dissipation under al1 normal operating conditions. If leakage of heat generating wastes from a storage tank occurs, the designed means of heat dissipation are compromised, and the thermal conditions that may occur outside the basic tank structure must be considered.

An obvious action to be taken after a detected tank failure is to remove the waste from the suspect tank. However, for alkaline wastes a major fraction of the heat generating fission products resides in a precipitated sludge that is dependent upon vaporization of liquid for heat dissipation. Arbitrary removal of the liquid cover to eliminate the source of leakage may result in greater problems than those associated with the initial leakage. The problem is further complicated by the ability of the soil surrounding the tank to sorb fission products and to filter out the dispersed fission-product-bearing solids.

Earlier work has been directed toward estimating the transient temperature gradients in the concrete tank 1 iner during normal operations, (1) and waste storage tank systems have been 
successfully simulated by analogs composed of electrically conductive paper. (2) The methods used in this report for steadystate thermal analysis of waste storage tanks containing solid cakes and boiling solutions are presented in BNWL-262.(3) The techniques for estimating soil temperatures in and around leaks containing heat generating radioactivity are described in $\mathrm{HW}-80848$. (4)

The theoretical internal tank temperatures calculated here are conservatively high because of the assumption of thermal equilibrium, which in some cases may require months to approach and which is always perturbed by radioactive decay of the heatgenerating source.

SUMMARY AND CONCLUSIONS

The temperatures and heat losses around waste tanks containing boiling solutions and heat generating sludge layers are compared for dry (low thermal conductivity) and wet (high thermal conductivity) soils. In all cases most of the conducted heat flows from the top of the tank, through the soil layer above the tank, and to the atmosphere. With the tank temperature held constant by boiling supernate that is refluxed by a condenser, more heat is dissipated into surrounding soil that is wet than is dissipated into dry soil. The temperature distribution throughout the soil-tank system is nearly independent of the moisture content of the soil if all the soil in the system has the same thermal conductivity; however, if a localized wet region appears only adjacent to the tank wall, higher temperatures will be found in this region of the soil than in nearby dry areas.

Removal of all liquid from waste tanks without removing the sludge can result in extremely high temperatures. If the supernate were removed from a typical alkaline waste tank, and the only means of heat removal from the radioactive sludge were conduction through 
the surrounding dry soil, equilibrium tank temperatures as high as $25,000^{\circ} \mathrm{F}$ can be calculated. Of course, the tank would collapse long before thermal equilibrium is reached, radically altering the heat transfer conditions. The adiabatic temperature rise is estimated to be less than $20 \mathrm{~F} / \mathrm{hr}$ so that a long time would be needed to approach the equilibrium temperature. Even after a 10 yr period of radioactive decay, the temperature can still be as high as $2000^{\circ} \mathrm{F}$. Passing cooling air through the tank offers little relief from this condition. At a flow rate of $100 \mathrm{ft}^{3} / \mathrm{min}$, calculated exit air and equilibrium tank temperatures are still greater than $10,000^{\circ} \mathrm{F}$. Spraying the dry sludge with water to keep its surface at the boiling point of water could keep the bottom of the tank below $500^{\circ} \mathrm{F}$, provided the cake were sufficiently thin and the sludge thermal conductivity were high.

Leaks of alkaline supernate containing only cesium and small amounts of ruthenium cannot cause dangerously high soil temperatures. In a 50,000 gal hemispherical leak of typical acid supernate, the maximum rise in concrete-soil interface temperature is on $1 \mathrm{y} 35^{\circ} \mathrm{F}$, with a maximum soil temperature rise of $524^{\circ} \mathrm{F}$ at a distance of $8 \mathrm{ft}$ from the tank wall. Even the flashing off of the water in the supernate at the leak point would not cause high temperatures because the large quantities of inert salts dilute the fission products. The leakage of even small volumes (less than 1000 gal) of alkaline sludge that might be slurried in the supernate or of acid solutions containing highly adsorbent zirconium and cerium could cause high temperatures at the concrete-soil interface because of the localized high concentrations of fission products at the leak point.

Temperature rise maps are provided for hemispherical leaks, varying from 100 to 100,000 gal, for wet and dry soil and for 
various types of fission products. These maps may prove useful in analyzing temperature records to determine the size and location of a leak. Accurate records are essential for such analyses, since the temperature rises are superimposed on a previously existing temperature gradient around intact tanks. A computer program is provided for calculating temperature rise maps around hemispherical leaks and hemispheroidal leaks of varying shapes. Higher temperatures are reached in prolate hemispheroidal leaks than in hemispherical leaks of equal volume.

\section{DISCUSSION}

Temperature Around Intact Tanks

Heat Generation Rates

A single underground radioactive waste storage tank may contain nearly a million gallons of alkaline waste. The high salt content and alkalinity result in a sludge layer which contains most of the heat generating fission products, such as strontium, cerium, zirconium-niobium, and ruthenium. Cesium and a small fraction of the ruthenium remain in the supernate. The heat generated in alkaline waste tanks may vary over a wide range depending upon the volume reduction achieved through self-concentration. For the purposes of this study, heat generation rates of $360 \mathrm{Btu} /(\mathrm{hr})\left(\mathrm{ft}^{3}\right.$ ) in the sludge and $2.64 \mathrm{Btu} / \mathrm{hr})\left(\mathrm{ft}^{3}\right)$ in the supernate were assumed. The bulk of the heat is generated in the sludge and is removed by boiling of the liquid with reflux condensation in an external cooling system. The estimated volumetric heat generation rate in a typical sludge is presented in Figure 1 as a function of aging of the waste. If the tank is left undisturbed, the heat generation rate will decrease 4 -fold in $1 \mathrm{yr}$ and 20 -fold in $10 \mathrm{yr}$. 


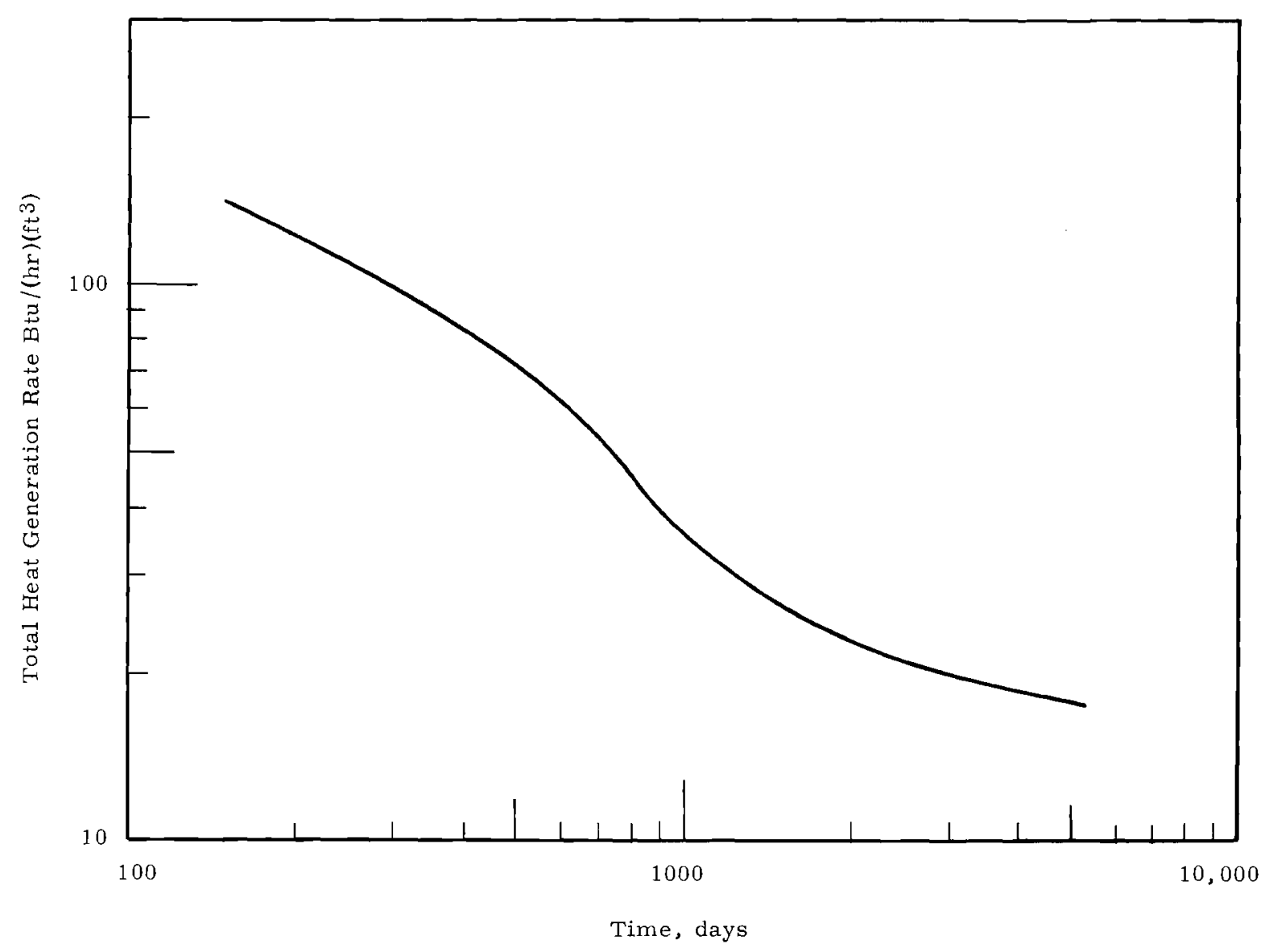

FIGURE 1 Volumetric Sludge Heat Generation Rate as a Function of Aging Time

Tanks Containing Boiling Solutions

For tanks containing boiling solutions, only a small fraction of the heat generated is conducted away from the tank through the soil. Therefore, the temperature of the boiling supernate $\left(230^{\circ} \mathrm{F}\right.$ in this case) is known more accurately than the heat conducted through the soil. Calculations were made using the methods given in BNWL-262 (3) to match the surrounding temperatures in the boiling supernate temperature. The system properties used in the calculations are given in Table $I$. The temperature field for dry soil [k=0.15 Btu/(hr)( $\left.\left.\mathrm{ft}^{2}\right)\left({ }^{\circ} \mathrm{F} / \mathrm{ft}\right)\right]$ is shown in Figure 2. The system was assumed to be insulated at 
a $60 \mathrm{ft}$ radius, which approximately simulates an infinite array of identical tanks in a tank farm. Since heat flow is greatest where isotherms are close together, Figure 2 shows that most of the conducted heat flows through the soil above the tank.

TABLE I

SYSTEM PROPERTIES FOR CALCULATIONS OF TEMPERATURES

WITH BOILING SOLUTIONS

Tank diameter

$75 \mathrm{ft}$

Center-to-center tank spacing

$120 \mathrm{ft}$

Soil overburden depth

$11 \mathrm{ft}$

Tank height

$36 \mathrm{ft}$

Depth of water table

$202 \mathrm{ft}$

Sludge thickness

$2 \mathrm{ft}$

Liquid depth

$20 \mathrm{ft}$

Air-to-soil heat transfer coefficient

$0,55 \mathrm{Btu} /(\mathrm{hr})\left(\mathrm{ft}{ }^{2}\right)\left({ }^{\circ} \mathrm{F}\right)$

Vapor space heat transfer coefficient

$1.5 \mathrm{Btu} /(\mathrm{hr})\left(\mathrm{ft} \mathrm{t}^{2}\right)\left({ }^{\mathrm{o}} \mathrm{F}\right)$

Sludge thermal conductivity (assuming boiling liquid in the sladge)

$875 \mathrm{Btu} /(\mathrm{hr})\left(\mathrm{ft} \mathrm{t}^{2}\right)\left({ }^{\circ} \mathrm{F} / \mathrm{ft}\right)$

$200 \mathrm{Btu} /(\mathrm{hr})\left(\mathrm{ft} \mathrm{C}^{2}\right)\left({ }^{\circ} \mathrm{F} / \mathrm{ft}\right)$

Vapor thermal conductivity

$875 \mathrm{Btu} /(\mathrm{hr})\left(\mathrm{ft} \mathrm{C}^{2}\right)\left({ }^{\mathrm{o}} \mathrm{F} / \mathrm{ft}\right)$

Liquid thermal conductivity

Soil temperatures and heat transferred through the soil are given in Table II for several conditions. For dry soil $(k=0.15)$ only about $16,000 \mathrm{Btu} / \mathrm{hr}$ are transferred through the soil to the surroundings at thermal equilibrium. This is only a small fraction of the heat generated in a $2 \mathrm{ft}$ thick layer of sludge. If all the soil j.s wet $(k=0.65)$ nearly $65,000 \mathrm{Btu} / \mathrm{hr}$ are transferred through the soil, but all of the temperatures in the system remain the same as for dry soll. If only a local region near the tank is wetted, the temperatures in and near the region rise because of the better heat transfer from the tank to the region. 


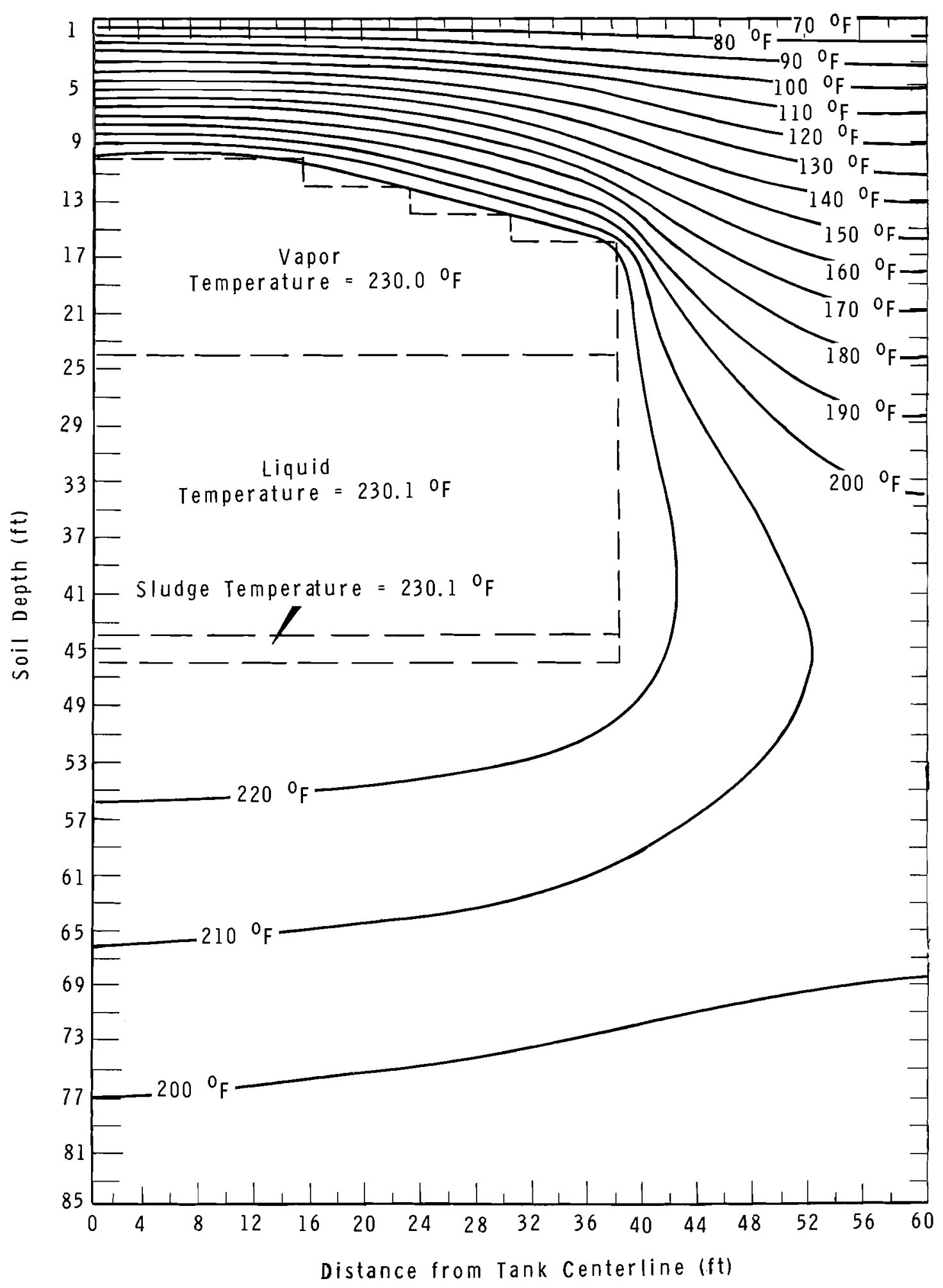

FIGURE 2 Temperatures Around an Underground Waste Storage Tank Containing a Boiling Solution - Dry Soil $\mathrm{k}=0.15 \mathrm{Btu} /(\mathrm{hr})\left(\mathrm{ft}^{2}\right)\left({ }^{\circ} \mathrm{F} / \mathrm{ft}\right)$ 
The assumed effective thermal conductivities for the vapor, liquid, and sludge are so high that the tank is essentially an isothermal region for the results in Figure 2 and Table II. For a real case, the sludge temperature will be somewhat higher than the liquid temperature because most of the heat generated originates in the sludge and its transfer from the sludge to the liquid where it is removed by evaporation is not included in these calculations. If the sludge thermal conductivity were near 1.0 (a reasonable value for a solid), the high actual heat generation rate would raise the sludge temperature to a value many times higher than that which is actually observed. The true effective thermal conductivity of the sludge must be very high due to boiling in the sludge;otherwise, much higher temperatures would be observed.

TABLE I I

THERMAL EFFECTS FOR DIFFERENT SOIL CONDITIONS

Input Data

Soil thermal conductivity

Btui (hr) $\left(f t^{2}\right)\left({ }^{0} \mathrm{~F} / \mathrm{ft}\right)$

Temperature of tank, ${ }^{\star} \mathrm{F}$

$\underline{\text { Dry Soil }} \quad \underline{\text { Wet Soil }}$

Local

Wet Region

$0.15 \quad 0.65 \quad 0.15^{(\mathrm{a})}$

230

230

Calculated Results

Centerline temperature, ${ }^{\circ} \mathrm{F}$

$5 \mathrm{ft}$ above the tank

150.4

150.4

150.8

$10 \mathrm{ft}$ below the tank

218.5

218.5

223.8

Heat conducted to ground surface, Btu/hr

$13,700 \quad 55,400 \quad 13,700$

Heat conducted to water table, Btu/hr

2,100

8,500

2,200

Total heat removed from tank

through the soil, Btu/hr

15,800

63,900

15,900

(a) A $7.5 \mathrm{ft}$ thick by $75 \mathrm{ft}$ diam slab of soil immediately below the tank has a thermal conductivity of $0.65 \mathrm{Btu} /(\mathrm{hr})\left(\mathrm{ft} \mathrm{t}^{2}\right.$ ) $\left({ }^{\circ} \mathrm{F} / \mathrm{ft}\right)$ 
Factors which might strongly influence the comparison of temperatures calculated in this report with real tank temperatures are the nonuniformity of the heat generating sludge layer, the wide variation in soil properties with position, and the errors introduced by inserting highly conductive measuring devices into the soll which is a good thermal insulator. The transient thermal gradients just after a cold tank is filled are much larger than the steady state values, and they are dissipated slowly so that higher heat losses will occur for weeks after startup.

Tanks Containing Sludge Only

After the supernate has been removed from a tank by leakage or by deliberate pumping of the supernate, the only method ramaining for heat removal from the tank is by conduction through the soil. If $2 \mathrm{ft}$ of sludge with a heat generation rate of 360 $\mathrm{Btu} /(\mathrm{hr})\left(\mathrm{ft}^{3}\right)$ were left in a tank, the heat generation rate would be $3,200,000 \mathrm{Btu} / \mathrm{hr}$. As is shown in Table III, the resulting temperatures would be extremely high if no change in tank geometry or mode of heat removal intervened. The temperatures in Table III were calculated with the same soil properties as for the boiling tanks except that the tank was assumed to be alone rather than in an array of tanks containing similar contents. The maximum calculated temperature in the cake is $23,900^{\circ} \mathrm{F}$, far above the boiling point of all the materials involved. If the same tank were placed in an infinite tank farm array of similar tanks, the maximum calculated temperature would be $34,20{ }^{\circ} \mathrm{F}$, about $43 \%$ higher than in Table III. All further discussions will be based on the infinjte array of Identical tanks, since the methods of calculation used here and described in BNWL-262 (3) are most easily applied to tank farm systems. 
TABLE III

TEMPERATURES AROUND A SOLITARY UNDERGROUND WASTE STORAGE TANK CONTAINING DRY SLUDGE

Soil Thermal Conductivity, $k=0.15 \mathrm{Btu} /(\mathrm{hr})\left(\mathrm{ft} \mathrm{t}^{2}\right)\left({ }^{\circ} \mathrm{F} / \mathrm{ft}\right)$

Temperatures are in degrees Fahrenheit

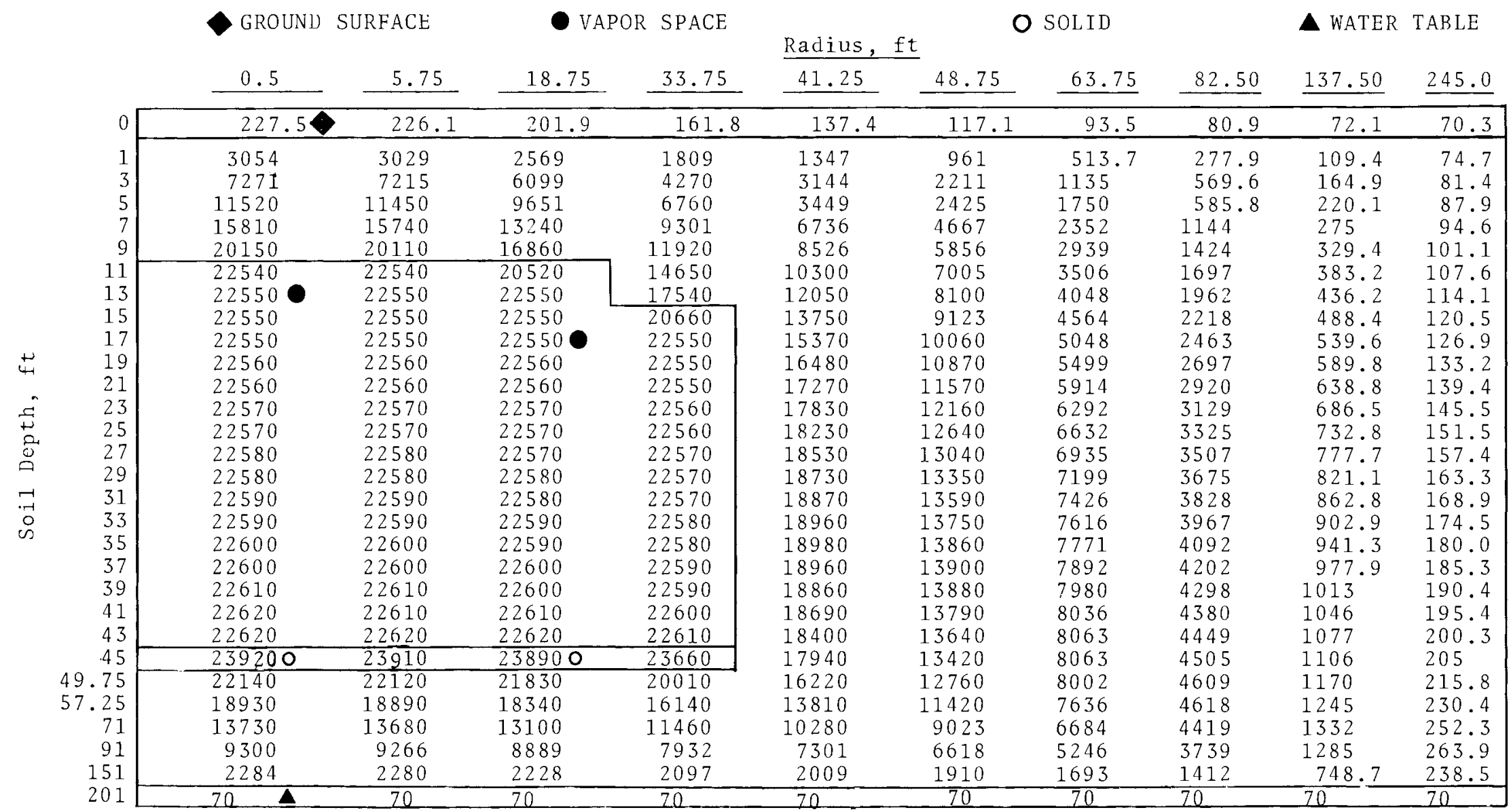


With a heat generation rate of $360 \mathrm{Btu} /(\mathrm{hr})\left(\mathrm{ft}^{3}\right)$, the adiabatic rate of temperature rise is about $17^{\circ} \mathrm{F} / \mathrm{hr}$. With this information and an estimate of the overall heat transfer coefficient for heat removal from the tank of $0.02 \mathrm{Btu} /(\mathrm{hr})\left(\mathrm{ft}^{2}\right)\left({ }^{\circ} \mathrm{F}\right)$, the temperature rise of the dry cake as a function of time can be estimated. The results shown in Table IV are only a rough estimate, since radioactive decay of the heat generators and the heat capacity of the soil and the concrete were not considered, but they do show that heating up of the tank is a slow process and that it would take about a year to approach the equilibrium temperatures given in Table III. After only a week, however, temperatures above $2000^{\circ} \mathrm{F}$ are reached in the sludge and in the vapor space of the tank. This would probably cause the tank to collapse. A more exact analysis of the transient temperatures in waste tanks is needed to estimate the time of irreversible damage.

TABLE IV

TEMPERATURE RISE IN CAKE (DRY)

$\begin{array}{rr}\text { Time, } h r & \text { Temperature, }{ }^{\circ} \mathrm{F} \\ 0 & 100 \\ 10 & 259 \\ 24(1 \text { day }) & 479 \\ 100 & 1,660 \\ 168 \text { (1 week }) & 2,859 \\ 720 \text { (1 month }) & 9,852 \\ 1000 & 12,834 \\ 5000 & 30,754 \\ \infty & 33,949\end{array}$


The assumption that equilibrium has been reached at each cooling time allows the maximum temperatures to be calculated as a function of cake thickness and time from the present. These temperatures are shown in Figure 3 for dry soil. The calculated temperatures at short cooling periods are much too high because the time to heat up to equilibrium is quite long, and the calculated temperatures at long cooling times are slightly low because the time for the tank to cool down is of the same order of magnitude as the half-lives of the heat generating fission products. An exact analysis of transient conditions in waste tanks would be too complex to be justified for the present case where it is clear that the temperatures are unreasonably high.

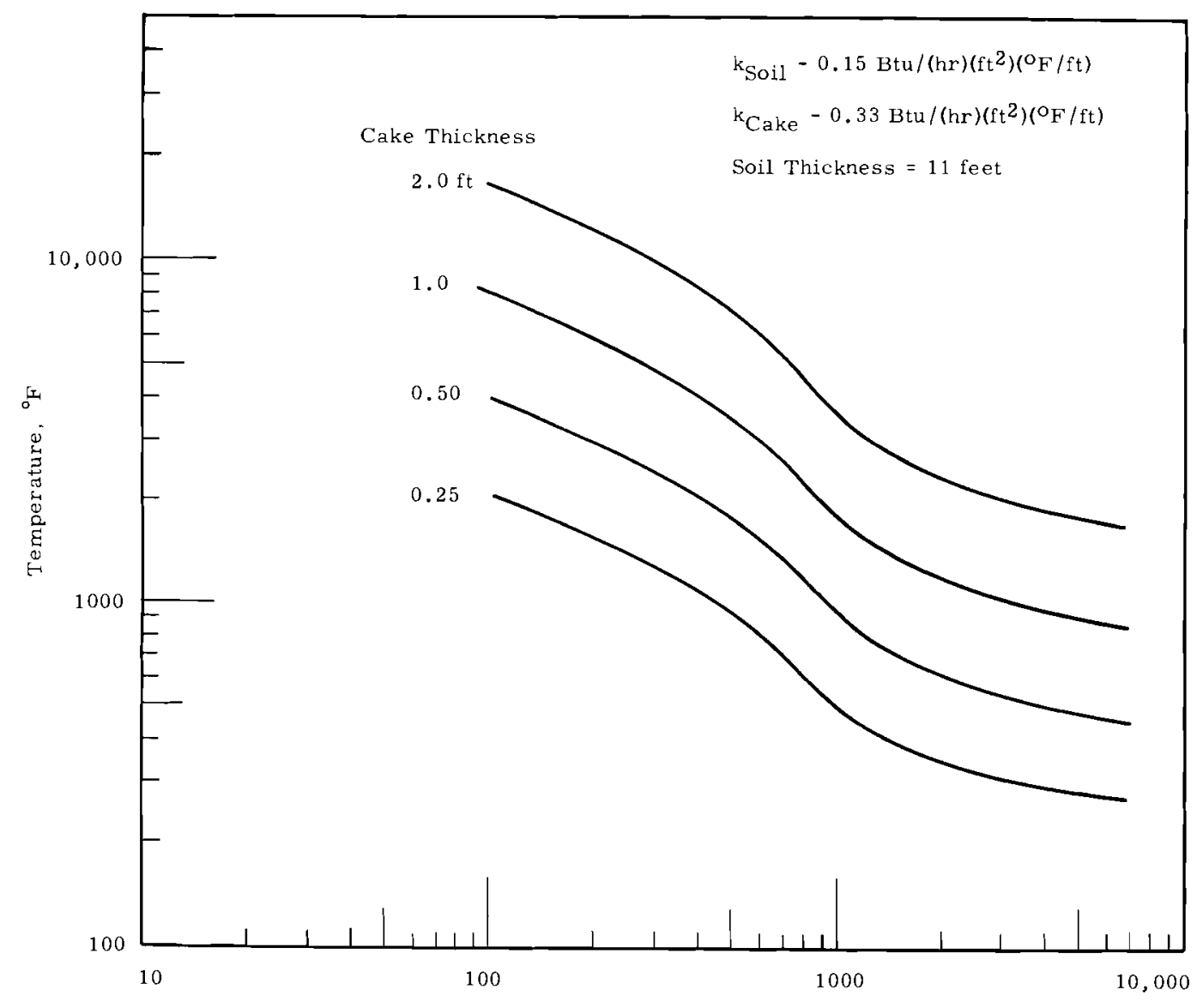

FIGURE 3 Temperature at the Bottom of the Cake as a Function of Cake Thickness and Radioactive Cooling Time 


\section{Methods for Maintaining Low Tank Temperatures}

Several steps have been suggested for lowering high temperatures in tanks. These include

- Wetting the soil above and beside the tank

- Passing cooling air through the vapor space

- Removing soil from above the tank

- Spraying the dry sludge with water.

Wetting the soil above the tank would reduce the temperature as long as the water remained in the soil. The thermal conductivity of wet soil is about 4 or 5 times that of dry soil and the sludge temperature is inversely proportional to the soil thermal conductivity. Vaporization of the water in soil would also remove heat.

Passing cooling air through the vapor space at the rates contemplated would not be effective. A temperature of $34,000^{\circ} \mathrm{F}$ for a $2 \mathrm{ft}$ cake is reduced to $15,000^{\circ} \mathrm{F}$ by passing $100 \mathrm{ft} / \mathrm{min}$ air through the vapor space. The exit air would be quite hot, near $14,000^{\circ} \mathrm{F}$.

Removing soil from above the tank would reduce the temperature, since it is approximately proportional to the overlying soil thickness. The amount of soil which could be removed would probably be limited by radioactive shielding considerations.

Spraying the dry sludge with water, and maintaining a liquid layer, would bring the surface of the cake to the boiling point of water. If the water did not penetrate the cake the temperature of the bottom of the cake would be a function of the cake thermal conductivity and the cake thickness as shown in Table V. Temperatures high enough to damage the tank liner could still be achieved in some cases; and, if the water spray were turned off, temperature elevation would begin. 
None of the above remedies appears to be an adequate substitute for the presence of a boiling solution percolating through the sludge. It is suggested that when the supernate is removed from a tank as much sludge as possible should be removed with it.

\section{TABLE V}

TEMPERATURE AT THE BOTTOM OF THE TANK

WHEN USING A WATER SPRAY ON CAKE SURFACE

\begin{tabular}{|c|c|c|c|c|c|}
\hline $\begin{array}{l}\text { Cake } \\
\text { Thick- } \\
\text { ness,ft } \\
\end{array}$ & $\begin{array}{l}\text { Thermal } \\
\frac{\text { Btu/(hr) }}{\text { Soil }}\end{array}$ & $\begin{array}{r}\begin{array}{l}\text { Conductivity } \\
\left(\mathrm{ft}^{2}\right)\left({ }^{\circ} \mathrm{F} / \mathrm{ft}\right)\end{array} \\
\text { Cake }\end{array}$ & $\begin{array}{l}\text { Aging } \\
\text { Time, } \\
\text { days } \\
\end{array}$ & $\begin{array}{l}\text { Volumetric Heat } \\
\text { Generation Rate, } \\
\left.\text { Btu/(hr)( } \mathrm{ft}^{3}\right) \\
\end{array}$ & $\begin{array}{l}\text { Temper- } \\
\text { ature, }{ }^{\circ} \mathrm{F}\end{array}$ \\
\hline \multirow[t]{9}{*}{2.0} & 0.15 & 0.33 & 180 & 129.56 & 1782 \\
\hline & & & 1000 & 36.00 & 648 \\
\hline & & & 3600 & 18.80 & 440 \\
\hline & & 0.80 & 180 & 129.56 & 860 \\
\hline & & & 1000 & 36.00 & 392 \\
\hline & & & 3600 & 18.80 & 306 \\
\hline & & 1.20 & 180 & 129.56 & 642 \\
\hline & & & 1000 & 36.00 & 332 \\
\hline & & & 3600 & 18.80 & 275 \\
\hline \multirow[t]{9}{*}{1.0} & 0.15 & 0.33 & 180 & 129.56 & 605 \\
\hline & & & 1000 & 36.00 & 321 \\
\hline & & & 3600 & 18.80 & 269 \\
\hline & & 0.80 & 180 & 129.56 & 374 \\
\hline & & & 1000 & 36.00 & 257 \\
\hline & & & 3600 & 18.80 & 236 \\
\hline & & 1.20 & 180 & 129.56 & 320 \\
\hline & & & 1000 & 36.00 & 242 \\
\hline & & & 3600 & 18.80 & 228 \\
\hline
\end{tabular}


Soil Temperatures Around Leaks

Since Purex waste tanks are surrounded by dense concrete, a leak appears to start from a hole in the concrete as shown in Figure 4 .

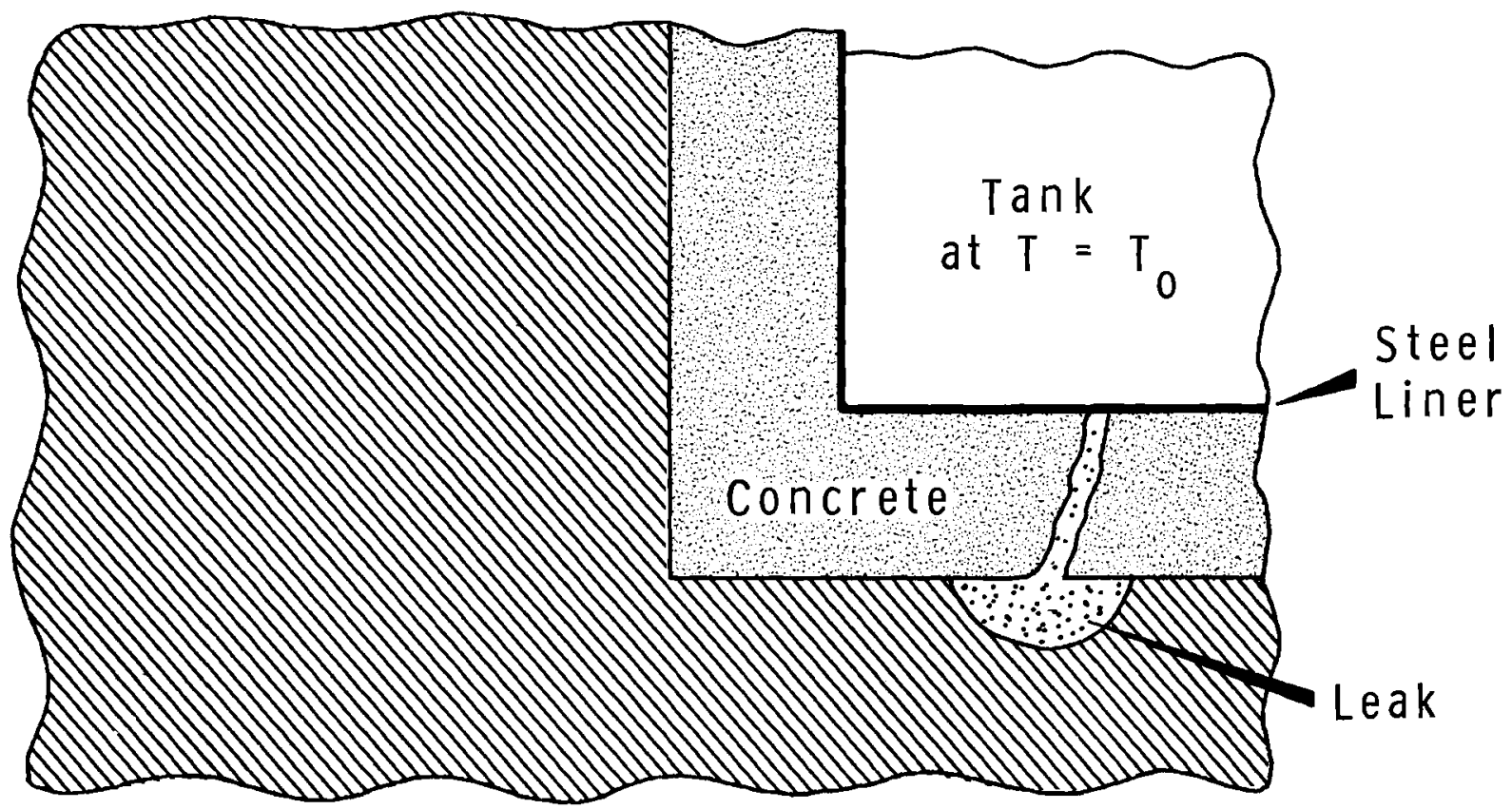

FIGURE 4 Schematic Diagram of a Leak in a Purex Waste Tank

The total volume of the leak is not usually equal to the volume of solution that leaked from the tank because the solution occupies only the void space in the soil and the fission products generating heat may concentrate by sorption on the soil or precipitation. The soil maybe only partially saturated with liquid because of capillary forces in the soil. The methods of deriving the equations are given in a previous report (4) and will not be discussed here. The basic assumptions, which are vital to an understanding of the results, are 1 isted below. 
(1) The leak is hemispheroidal.

(2) The heat generating material is uniformly distributed throughout the leak volume which is completely saturated with liquid.

(3) The leak is small enough so that the tank wall may be represented as an infinite surface.

(4) The size of the leak stabilizes long enough for steady state temperatures to be reached.

(5) The thermal properties of the soil are uniform.

(6) All the leak water has evaporated so that the thermal properties of the soil are the same inside the leak volume as in the external soil.

(7) The soil temperature at infinite distance from the tank is the same as the tank temperature.

Assumption 6 may be the most unrealistic one for evaluating the true temperatures in a leak; the presence of water may increase the thermal conductivity of the soil by a factor of 4 or or 5 , reducing the temperature within the leak volume appreciably. On the other hand, a leak will eventually dry up; and highest soil temperatures will be reached without water in the system. For a detailed analysis of the effect of soll characteristics and moisture content upon soil thermal properties, the reader is referred to a recent review by the American Institute of Electrical Engineers. (5)

Assumption 7 may be removed by superimposing the calculated temperature rises caused by the leak upon the temperature field around an intact tank as is shown in Figures 10 and 11. (Pages 26 and $2 ?$. 
Three chemical types of fission products were considered in this analysis:

- $\mathrm{Cs}^{137}$ and $\mathrm{Sr}^{90}$ sorb on the soil with a volumetic distribution coefficient $\mathrm{K}_{\mathrm{D}}$ of 0.6 (Ci/ft ${ }^{3}$ of soil) $/ \mathrm{Ci} / \mathrm{ft}^{3}$ of solution). Coincidentally, a $\mathrm{K}_{\mathrm{D}}$ of 0.6 combined with $\mathrm{a}$ soil void fraction of 0.35 makes the final volume of soil within the leak equal to the initial volume of solution which leaked from the tank.

- Ru does not sorb on the soil.

- $\quad \mathrm{Zr}-\mathrm{Nb}^{95}$ and $\mathrm{Ce}^{144}$ are present only in the sludge in alkaline tanks or in solution in acid tanks and precipitate or sorb in the soil to give effective distribution coefficients greater than 500 .(6) The question of whether these fission products precipitate due to high pH or sorb is an interesting one, since if they precipitate they might eventually redissolve in an acid leak or be dispersed throughout a greater volume of soil, thus reducing the thermal hazard. Present data indicates that the cerium precipitates and the zirconium sorbs. (6)

\section{Alkaline Supernate Leaks}

In Figure 5 are shown the isotherms around a 5000 gal hemispherical leak of alkaline supernate containing only $\mathrm{Cs}^{137}$ at 8 Ci/liter with a corresponding heat generation rate of $2.64 \mathrm{Btu} /(\mathrm{hr})\left(\mathrm{ft}^{3}\right)$. The void fraction in the soil is 0.35 . After the water has evaporated, the leak stabilizes to a radius of $6.95 \mathrm{ft}$. The background temperature is assumed to be zero everywhere. The two temperatures of greatest interest, the concrete-soil interface temperature and the maximum soil temperature, are $31.1^{\circ} \mathrm{F}$ and $129.2^{\circ} \mathrm{F}$ for this case.

The temperature variations are shown as a function of leak volume in Figure 6. It is clear that the concrete-soil interface 


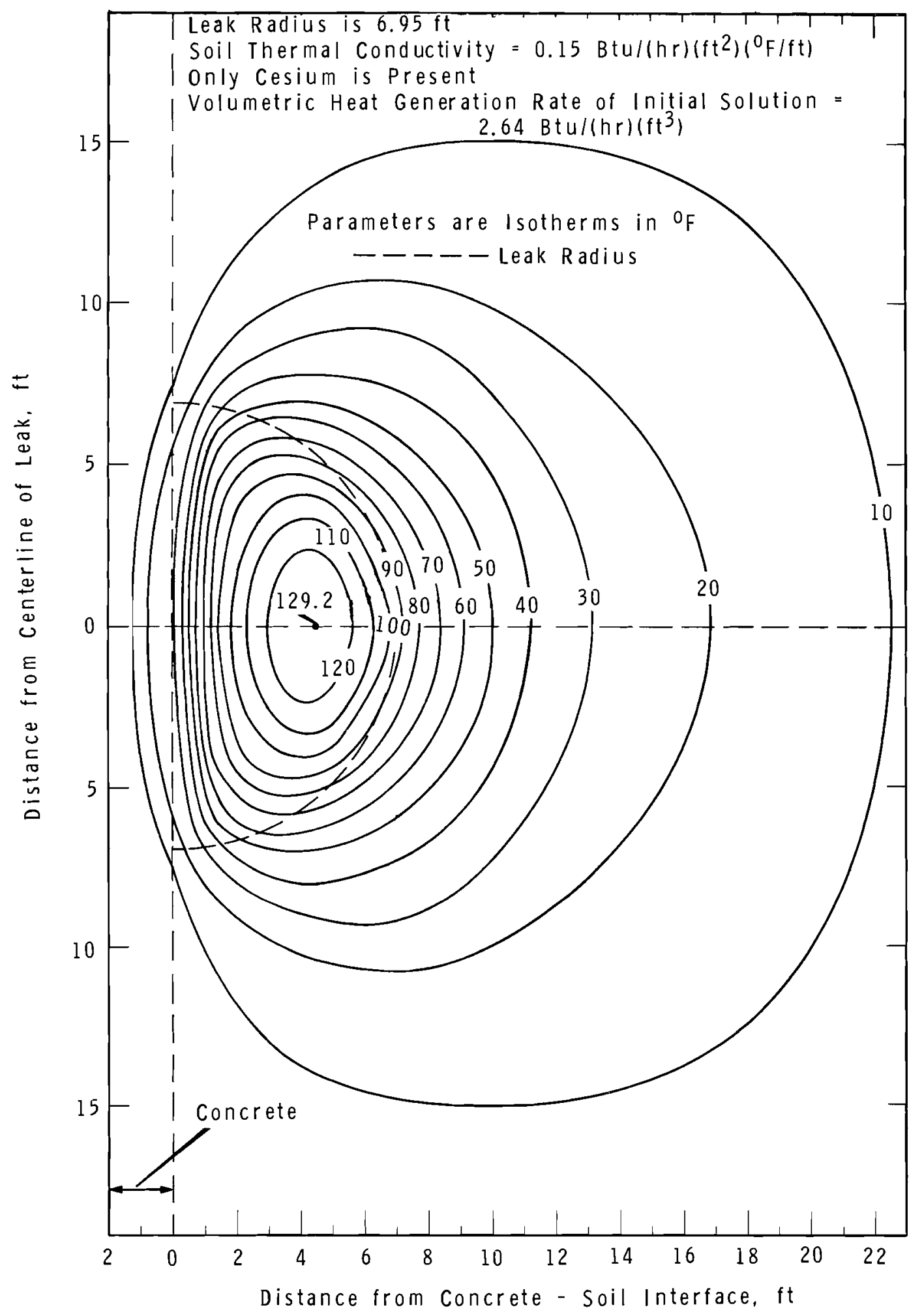

FIGURE 5 Temperature Rises Near a 5000 gal Hemispherical Leak of Alkaline Supernate 
temperature after increase stays below $50^{\circ} \mathrm{F}$ for all conditions and that even a 50,000 gal leak has a maximum soil temperature rise remains below $550^{\circ} \mathrm{F}$ at $10 \mathrm{ft}$ from the tank wall.

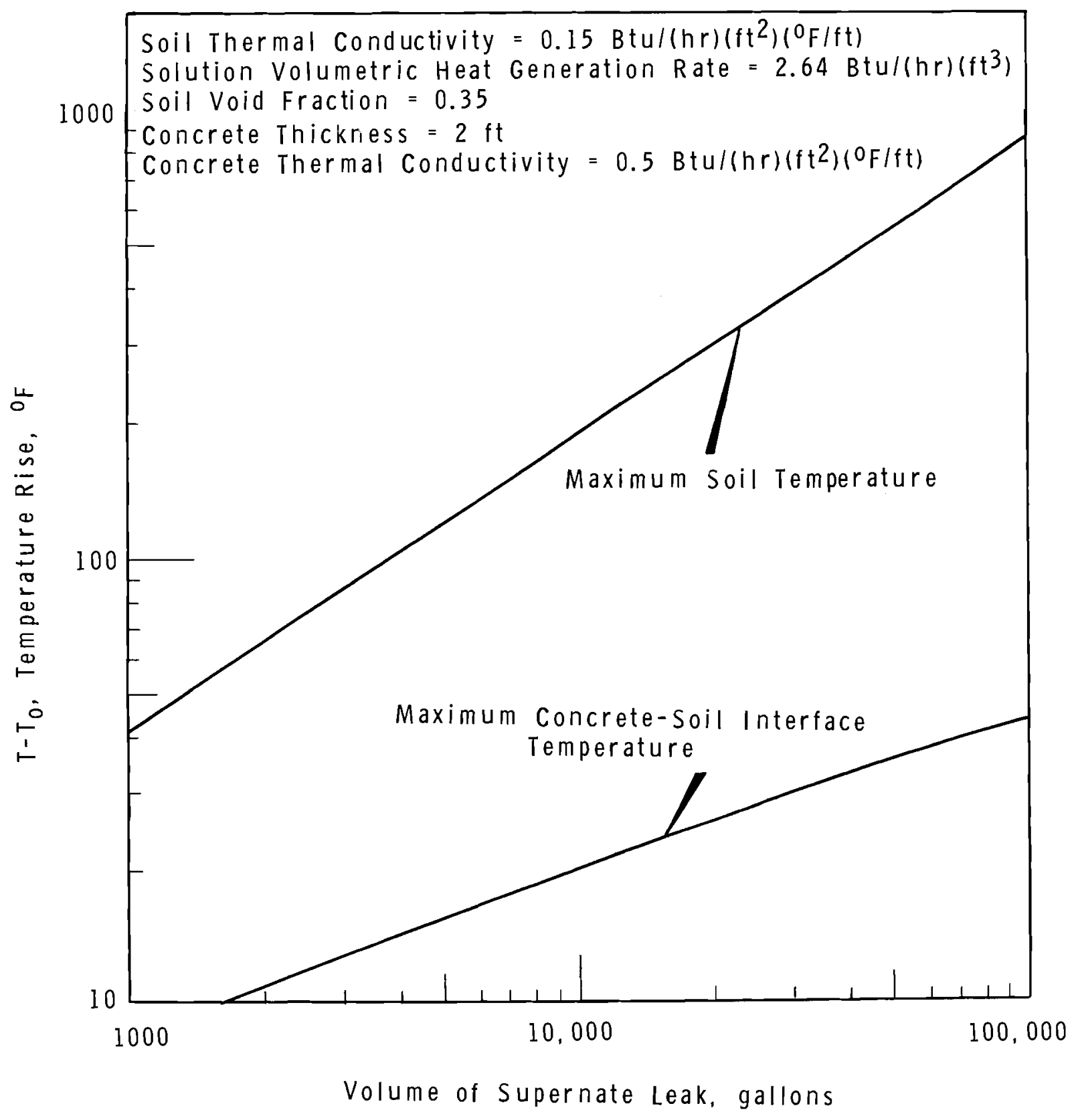

FIGURE 6 Soil Temperatures in Supernate Leak as a Function of Leak Volume 
The effect of variation in shape of the leak upon the maximum temperature is shown in Figure 7. The 5000 gal leak is allowed to elongate into a prolate hemispheroid and to spread along the tank wall to form an oblate hemispheroid without changing total volume. The leak dimensions are given in Figure 8 as a function of leak shape. As the eccentricity (the ratio of the leak radius at the tank wall to the maximum penetration depth into the soil) is varied, the maximum soil temperature passes through a maximum at an eccentricity of 0.25 , which defines an elongated, prolate leak. The concrete-soil interface temperature is nearly independent of leak shape, which indicates the hemisphere results are applicable to other shape leaks; however, the eccentricity at which the maximum soil temperature occurs changes with leak volume.

If the water in the supernate had flashed off to steam as it left the tank, leaving behind salts to fill the pores of the soil, and then more liquid percolated through the dried salts, the cesium and strontium could be distributed throughout the soil without sorbing. Since the sodium concentration in solidified typical alkaline supernate is about $2 \underline{2 \mathrm{M}}$, the initial concentration in the supernate is about $7 \underline{\mathrm{M}}$, and the void fraction in the soil is only 0.35 , no great concentration of fission products is effected and the temperature distribution is coincidentally the same as for a regular supernate leak.

The temperature rises for a variety of cases are compared in Table VI for an initial solution heat generation rate of 1.0 $\mathrm{Btu} /(\mathrm{hr})\left(\mathrm{ft}{ }^{3}\right)$. Temperatures for other heat generation rates may be found by simple ratio. The importance of soil thermal conductivity and fission product sorption is quite evident. Leaks from acid tanks could result in much higher temperatures than from alkaline tanks because the cerium and zirconium may concentrate at the point of the leak and produce high volumetric heat generation rates. 


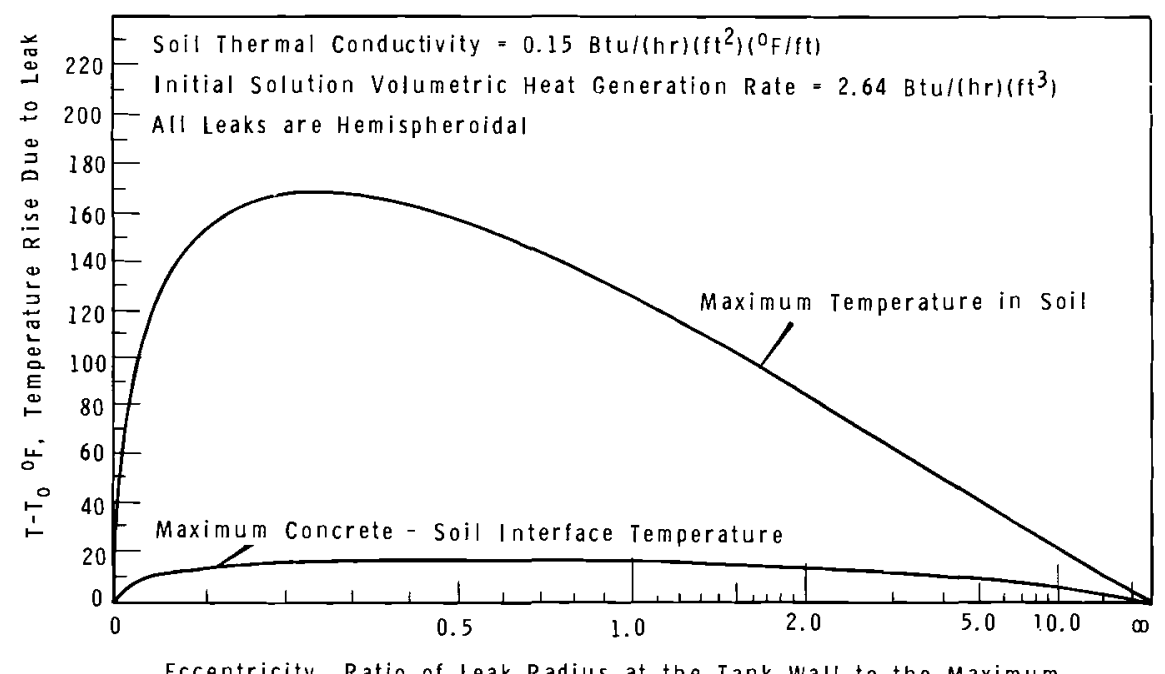

Eccentricity, Ratio of Leak Radius at the Tank Wall to the Maximum Penetration Depth of the Solution into the Soil

\section{FIGURE 7 Effect of Leak Shape on Maximum Soil Temperature,} 5000 gal Leak of Alkaline Supernate

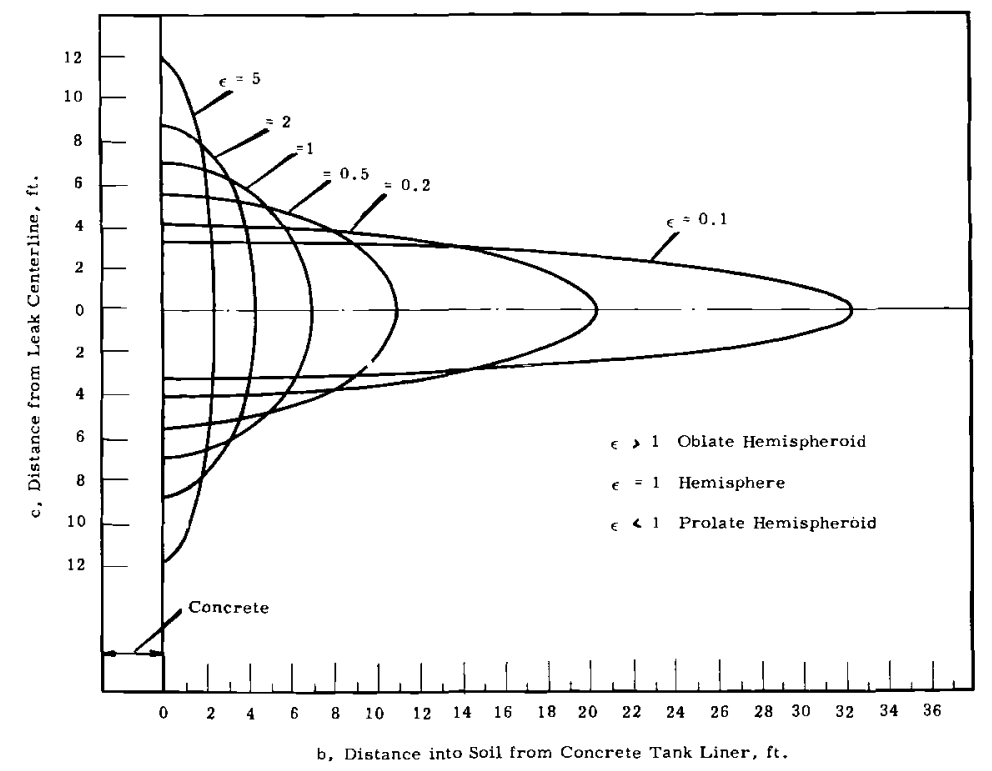


TABLE VI

TEMPERATURE RISES IN UNDERGROUND TANK LEAKS

\begin{tabular}{|c|c|c|c|c|}
\hline $\begin{array}{c}\text { Fission } \\
\text { Product } \\
\text { Distribution } \\
\text { Coefficient } \\
\end{array}$ & $\begin{array}{l}\text { Soil Thermal } \\
\text { Conductivity }\end{array}$ & $\begin{array}{r}\text { Leak } \\
\text { Radius, } \mathrm{ft} \\
\end{array}$ & $\begin{array}{l}\text { Maximum Wall } \\
\text { Temperature, }{ }^{\circ} \mathrm{F}\end{array}$ & $\begin{array}{l}\text { Maximum Soil } \\
\text { Temperature, }{ }^{\circ} \mathrm{F}\end{array}$ \\
\hline $\mathrm{K}_{\mathrm{D}}$ & $\mathrm{k}$ & $\mathrm{a}$ & $\mathrm{T}-\mathrm{T}_{0}$ & $\mathrm{~T}-\mathrm{T}_{\mathrm{O}}$ \\
\hline $\begin{array}{l}0(1) \\
0 \\
0.6(2) \\
0.6\end{array}$ & $\begin{array}{l}0.15 \\
0.6 \\
0.15 \\
0.6\end{array}$ & $\begin{array}{l}5.67 \\
5.67 \\
4.07 \\
4.07\end{array}$ & $\begin{array}{l}1.9 \\
1.5 \\
3.5 \\
2.7\end{array}$ & $\begin{array}{r}11.2 \\
3.2 \\
16.4 \\
5.0\end{array}$ \\
\hline $\begin{array}{l}0 \\
0 \\
0.6 \\
0.6\end{array}$ & $\begin{array}{l}0.15 \\
0.6 \\
0.15 \\
0.6\end{array}$ & $\begin{array}{l}9.70 \\
9.70 \\
6.95 \\
6.95\end{array}$ & $\begin{array}{l}3.3 \\
2.9 \\
6.2 \\
5.3\end{array}$ & $\begin{array}{r}32.6 \\
9.2 \\
47.4 \\
13.5\end{array}$ \\
\hline $\begin{array}{l}0 \\
0 \\
0.6 \\
0.6\end{array}$ & $\begin{array}{l}0.15 \\
0.6 \\
0.15 \\
0.6\end{array}$ & $\begin{array}{r}12.22 \\
12.22 \\
8.76 \\
8.76\end{array}$ & $\begin{array}{l}4.1 \\
3.8 \\
8.0 \\
7.0\end{array}$ & $\begin{array}{l}52.6 \\
14.3 \\
74.0 \\
20.8\end{array}$ \\
\hline $\begin{array}{l}0 \\
0 \\
0.6 \\
0.6\end{array}$ & $\begin{array}{l}0.15 \\
0.6 \\
0.15 \\
0.6\end{array}$ & $\begin{array}{l}16.58 \\
16.58 \\
11.89 \\
11.89\end{array}$ & $\begin{array}{r}5.7 \\
5.3 \\
10.9 \\
9.9\end{array}$ & $\begin{array}{r}96.0 \\
25.7 \\
134.9 \\
37.0\end{array}$ \\
\hline $\begin{array}{l}0 \\
0 \\
0.6 \\
0.6\end{array}$ & $\begin{array}{l}0.15 \\
0.6 \\
0.15 \\
0.6\end{array}$ & $\begin{array}{l}20.89 \\
20.89 \\
14.98 \\
14.98\end{array}$ & $\begin{array}{r}7.2 \\
6.8 \\
13.9 \\
12.8\end{array}$ & $\begin{array}{r}149.6 \\
39.3 \\
209.4 \\
57.1\end{array}$ \\
\hline $\begin{array}{l}0 \\
0 \\
0.6 \\
0.6\end{array}$ & $\begin{array}{l}0.15 \\
0.6 \\
0.15 \\
0.6\end{array}$ & $\begin{array}{l}26.32 \\
26.32 \\
18.87 \\
18.87\end{array}$ & $\begin{array}{r}9.1 \\
8.7 \\
17.5 \\
16.5\end{array}$ & $\begin{array}{r}237.9 \\
62.5 \\
329.6 \\
88.4\end{array}$ \\
\hline $\begin{array}{l}500(3) \\
500\end{array}$ & $\begin{array}{l}0.15 \\
0.6\end{array}$ & $\begin{array}{l}0.23 \\
0.23\end{array}$ & $\begin{array}{l}35.4 \\
10.7\end{array}$ & $\begin{array}{l}-- \\
--\end{array}$ \\
\hline $\begin{array}{l}500 \\
500\end{array}$ & $\begin{array}{l}0.15 \\
0.6\end{array}$ & $\begin{array}{l}0.40 \\
0.40\end{array}$ & $\begin{array}{l}87.8 \\
29.8\end{array}$ & $\begin{array}{l}-- \\
--\end{array}$ \\
\hline $\begin{array}{l}500 \\
500\end{array}$ & $\begin{array}{l}0.15 \\
0.6\end{array}$ & $\begin{array}{l}0.50 \\
0.50\end{array}$ & $\begin{array}{r}126.8 \\
46.0\end{array}$ & $\begin{array}{l}-- \\
--\end{array}$ \\
\hline $\begin{array}{l}500 \\
500\end{array}$ & $\begin{array}{l}0.15 \\
0.6\end{array}$ & $\begin{array}{l}0.86 \\
0.86\end{array}$ & $\begin{array}{l}279.3 \\
122.4\end{array}$ & $\begin{array}{l}-- \\
--\end{array}$ \\
\hline $\begin{array}{l}500 \\
500\end{array}$ & $\begin{array}{l}0.15 \\
0.6\end{array}$ & $\begin{array}{l}1.08 \\
1.08\end{array}$ & $\begin{array}{l}382.1 \\
183.5\end{array}$ & $\begin{array}{l}606.5 \\
190.1\end{array}$ \\
\hline $\begin{array}{l}500 \\
500\end{array}$ & $\begin{array}{l}0.15 \\
0.6\end{array}$ & $\begin{array}{l}1.47 \\
1.47\end{array}$ & $\begin{array}{l}566.1 \\
307.1\end{array}$ & $\begin{array}{r}1237.0 \\
403.8\end{array}$ \\
\hline $\begin{array}{l}500 \\
500\end{array}$ & $\begin{array}{l}0.15 \\
0.6\end{array}$ & $\begin{array}{l}1.85 \\
1.85\end{array}$ & $\begin{array}{l}751.6 \\
445.9\end{array}$ & $\begin{array}{r}2003.4 \\
642.7\end{array}$ \\
\hline
\end{tabular}


Leaks of small quantities of sludge into the soil can cause high temperatures at the soil-concrete interface because the specific heat generation rate of the sludge is over 100 times greater than that of the supernate. It is unlikely that sludge would leak out of the tank, but if sludge suspended in the supernate leaked into the soil and concentrated in the soil near the leak point an equivalent result would be obtained. Calculations similar to those used to produce Table VI show that a sludge leak of 175 gal could raise the soil temperature to $1500^{\circ} \mathrm{F}$ above the tank temperature. Experiments (6) have shown that solids suspended in the supernate tend to collect in the soil at the point of leakage and block off the further penetration of solids into the soil.

\section{Calculation of Temperatures Around Leaks}

No analytical solutions have been found for the general case of temperatures around even a hemispherical leak. A summary of the general solutions is given in Appendix A. Consequently, a computer program called GULP, for determining temperature around hemispherical and hemispheroidal leaks was devised. Temperature rise maps computed by GULP are presented in Appendix $B$ for the 38 cases 1 isted in Table VI. Some accuracy was sacrificed to obtain the wide range of variation desired. The poorest accuracy was obtained on the centerline of the leak at the concrete near the leak point, where estimated temperature rises may be high by a factor of two. At the point of maximum temperature, the values are within 5\% of the correct ones. After Appendix B was compiled, the computer program was modified to calculate the temperatures along the leak centerline by the analytical solutions discussed below.

Analytical solutions, available only for temperatures along the centerlines of leaks, are presented in Appendix A for hemispherical and hemispheroidal leaks. For a hemispherical leak the 
temperature rise in degrees Fahrenheit at the leak point is particularly simple:

$$
\mathrm{T}-\mathrm{T}_{\mathrm{o}}=\frac{\mathrm{Sa}^{2}}{\mathrm{k}}\left\{\frac{1}{6}\left(\frac{\mathrm{mk}}{\mathrm{ak}}\right)^{2}+\frac{1-\left[1+\left(\mathrm{mk} / \mathrm{ak}_{\mathrm{m}}\right)^{2}\right]^{3 / 2}}{6 \mathrm{mk} / \mathrm{ak}_{\mathrm{m}}}\right\}
$$

where $S$ is the volumetric heat generation rate of fission products in the soil, Btu/(hr) $\left(f t^{3}\right) ; m$ is the concrete liner thickness, $f t ; k$ is the thermal conductivity of the soil, $\mathrm{Btu} /(\mathrm{hr})\left(\mathrm{ft} \mathrm{C}^{2}\right)\left(\mathrm{C}^{\circ} \mathrm{F} / \mathrm{ft}\right) ; \mathrm{k}_{\mathrm{m}}$ is the thermal conductivity of the concrete; and a is the radius of the hemispherical leak, ft.

Temperature maps calculated by GULP for examples of the three classes of hemispheroidal leaks are given in Table VII. The distance away from the concrete is given by $B$ in feet, and the distance from the axis of the leak is given by $C$ in feet. The temperatures on the axis $(C=0)$ were calculated by an exact equation, and the temperatures not on the centerline were calculated by finite difference techniques.

Because of the nature of the heat sources involved, it is possible to superimpose the results of several calculations. Thus, the temperature around a 5000 gal acid leak of solution which initially contained heat generation of $1 \mathrm{Btu} / \mathrm{hr})\left(\mathrm{ft}{ }^{3}\right)$ each by cesium-strontium, zirconium-cerium, and ruthenium can be built up by superimposing Cases 5, 7, and 31 of Appendix B as is shown in Figure 9.

The most useful aspect of superimposition of leak temperatures involves adding the temperature rise in the leak to the undisturbed temperature around the tank to obtain the total temperature in the leak. Thus, any one of the 38 cases in Appendix $B$ could be added to the temperature given in Figure 2 for intact tanks. Such additions are shown in Figure 10 for a 5000 gal leak of alkaline supernate into dry soil and in Figure 11 for a 50,000 gal leak. 
TABLE VII

TEMPERATURE RISE MAPS FOR HEMISPHEROIDAL LEAKS

$\begin{array}{rlrl}m=\text { Concrete thickness, feet } & =2.0 & V=\text { Leak volume }=5000 \text { gal } \\ E=\text { Void fraction in soil } & =0.350 & \mathrm{~S}^{\prime}=\text { Heat generation rate of initial solution, } \\ K_{D}=\text { Distribution coefficient } & =0.600 & & 1.0 \mathrm{Btu} /(\mathrm{hr})\left(\mathrm{ft}{ }^{3}\right) \\ \mathrm{k}=\text { Soil, Btu/(hr) }\left(\mathrm{ft}^{2}\right)\left({ }^{\circ} \mathrm{F} / \mathrm{ft}\right) & =0.150 & \mathrm{R}=\text { Concentration factor }=1.053 \\ k_{m}=\text { Concrete, Btu/(hr) }\left(\mathrm{ft}^{2}\right)\left({ }^{\circ} \mathrm{F} / \mathrm{ft}\right) & =0.500 & \end{array}$

(Temperature rises are in degrees Fahrenheit)

Prolate Hemispheroidal Leak, $\varepsilon=0.5 \quad$ Leak length, $a=11.03 \mathrm{ft}$

\begin{tabular}{llllllllll}
$C$ ACROSS & 30.0 & 20.0 & 15.0 & 10.0 & 8.0 & 6.0 & 4.0 & 2.0 & .0 \\
\hline
\end{tabular}

\begin{tabular}{|c|c|c|c|c|c|c|c|c|c|}
\hline .00 & $\cdot 1$ & .2 & .5 & $1 \cdot 4$ & $2 \cdot 5$ & $5 \cdot 1$ & 9.5 & 11.6 & 6.5 \\
\hline $\begin{array}{l}1.00 \\
2.00\end{array}$ & $\begin{array}{l}.2 \\
.3\end{array}$ & $\begin{array}{l}.6 \\
.9\end{array}$ & $\begin{array}{l}1 \cdot 3 \\
2 \cdot 1\end{array}$ & $\begin{array}{l}3.8 \\
5.9\end{array}$ & $\begin{array}{r}6.5 \\
10.0\end{array}$ & $\begin{array}{l}12.8 \\
18.8\end{array}$ & $\begin{array}{l}23 \cdot 2 \\
32.9\end{array}$ & $\begin{array}{l}28.5 \\
40.6\end{array}$ & $\begin{array}{l}25.5 \\
39.4\end{array}$ \\
\hline 4.40 & .6 & 1.7 & 3.7 & 9.7 & 15.4 & 26.2 & 44.0 & 55.5 & 57.0 \\
\hline 5.00 & .6 & 1.9 & 4.0 & 10.3 & 16.1 & 26.7 & 44.6 & 56.7 & 58.6 \\
\hline 6.95 & .8 & $2 \cdot 4$ & 4.8 & $11 \cdot 3$ & 16.9 & 26.0 & $41 \cdot 7$ & $55 \cdot 1$ & $58 \cdot 1$ \\
\hline 8.00 & .9 & 2.6 & 5.1 & 11.4 & 16.5 & $24 \cdot 5$ & 37.4 & 51.2 & 54.6 \\
\hline $\begin{array}{l}10.00 \\
15.00\end{array}$ & $\begin{array}{l}1 \cdot 1 \\
1.3\end{array}$ & $\begin{array}{l}2.9 \\
3.1\end{array}$ & $\begin{array}{l}5.4 \\
5.1\end{array}$ & $\begin{array}{r}11.0 \\
8.4\end{array}$ & $\begin{array}{l}15.0 \\
10.1\end{array}$ & $\begin{array}{l}20.6 \\
12.1\end{array}$ & $\begin{array}{l}28.4 \\
14.0\end{array}$ & $\begin{array}{r}38.7 \\
15.4\end{array}$ & $\begin{array}{l}42.6 \\
15.5\end{array}$ \\
\hline $\begin{array}{l}20.00 \\
30.00\end{array}$ & $\begin{array}{l}1.4 \\
1.3\end{array}$ & $\begin{array}{l}2.9 \\
2.1\end{array}$ & $\begin{array}{l}4.2 \\
2.6\end{array}$ & $\begin{array}{l}5.9 \\
3.1\end{array}$ & $\begin{array}{l}6.7 \\
3.3\end{array}$ & $\begin{array}{l}7.4 \\
3.5\end{array}$ & $\begin{array}{l}8.0 \\
3.6\end{array}$ & $\begin{array}{l}8.4 \\
3.7\end{array}$ & $\begin{array}{l}8.2 \\
3.5\end{array}$ \\
\hline
\end{tabular}

Hemispherical leak, $\varepsilon=1.0$

Leak length $a=6.95 \mathrm{ft}$

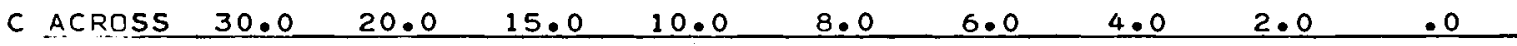

B DOWN

\begin{tabular}{|c|c|c|c|c|c|c|c|c|c|}
\hline .00 & .0 & .1 & .4 & 1.4 & 3.1 & $7 \cdot 3$ & 10.0 & 11.3 & 6.2 \\
\hline $\begin{array}{l}1.00 \\
2.00\end{array}$ & $\begin{array}{l}.1 \\
.2 \\
\end{array}$ & $\begin{array}{r}.4 \\
.7 \\
\end{array}$ & $\begin{array}{l}1.1 \\
1.7\end{array}$ & $\begin{array}{l}3.8 \\
5.8\end{array}$ & $\begin{array}{r}7 \cdot 7 \\
11 \cdot 1 \\
\end{array}$ & $\begin{array}{l}17.4 \\
23.4\end{array}$ & $\begin{array}{l}24 \cdot 1 \\
33 \cdot 3\end{array}$ & $\begin{array}{l}27.5 \\
38.5\end{array}$ & $\begin{array}{l}24.1 \\
36.5 \\
\end{array}$ \\
\hline 4.40 & .4 & $1 \cdot 3$ & $2 \cdot 9$ & $8 \cdot 5$ & 14.2 & 24.6 & 38.6 & 47.0 & 47.4 \\
\hline 5.00 & .4 & 1.4 & 3.2 & 8.8 & $14 \cdot 1$ & $23 \cdot 4$ & 36.8 & 45.7 & 46.5 \\
\hline 6.95 & .6 & 1.8 & 3.7 & 8.9 & 13.0 & 19.0 & 26.5 & 33.7 & 35.3 \\
\hline 8.00 & .6 & 1.9 & 3.8 & 8.6 & 12.1 & 16.7 & $22 \cdot 1$ & 26.9 & 27.5 \\
\hline $\begin{array}{l}10.00 \\
15.00\end{array}$ & $\begin{array}{r}.7 \\
.9\end{array}$ & $\begin{array}{l}2 \cdot 1 \\
2.2\end{array}$ & $\begin{array}{l}3.9 \\
3.5\end{array}$ & $\begin{array}{l}7.8 \\
5.5\end{array}$ & $\begin{array}{r}10.2 \\
6.5\end{array}$ & $\begin{array}{r}13 \cdot 1 \\
7.5\end{array}$ & $\begin{array}{c}16.1 \\
8.3\end{array}$ & $\begin{array}{r}.18 .4 \\
8.9\end{array}$ & $\begin{array}{r}18.3 \\
8.6\end{array}$ \\
\hline 20.00 & 1.0 & 2.0 & 2.8 & 3.9 & $4 \cdot 3$ & 4.7 & 5.0 & 5.2 & 4.9 \\
\hline 30.00 & .9 & 1.4 & 1.7 & 2.1 & 2.2 & $2 \cdot 3$ & $2 \cdot 3$ & 2.4 & 2,2 \\
\hline
\end{tabular}

Oblate hemispheroidal leak, $\varepsilon=2.0$

Leak length, $a=4.38 \mathrm{ft}$

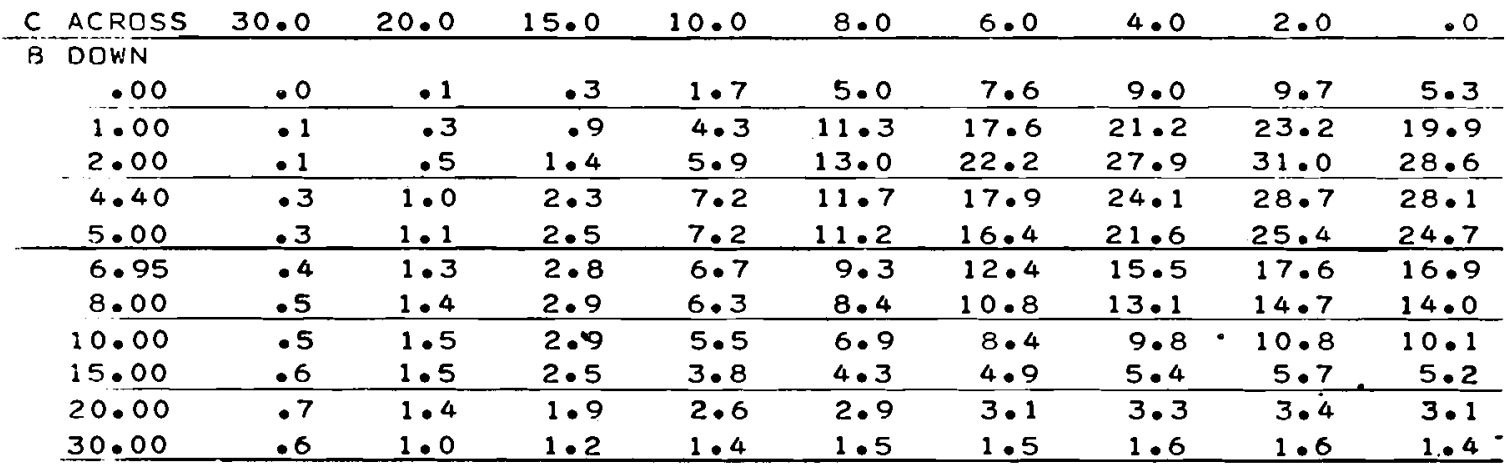




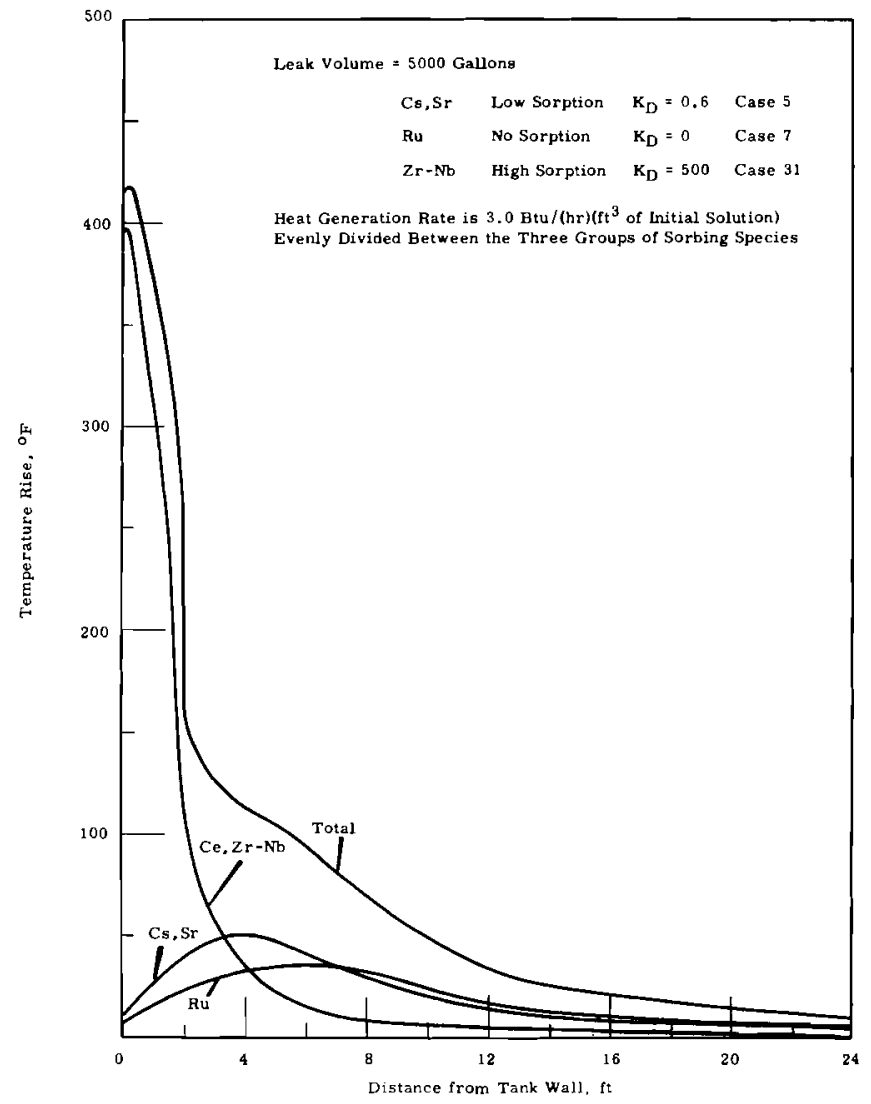

$\underline{\text { FIGURE } 9}$ Leak Centerline Temperatures in an Acid Leak

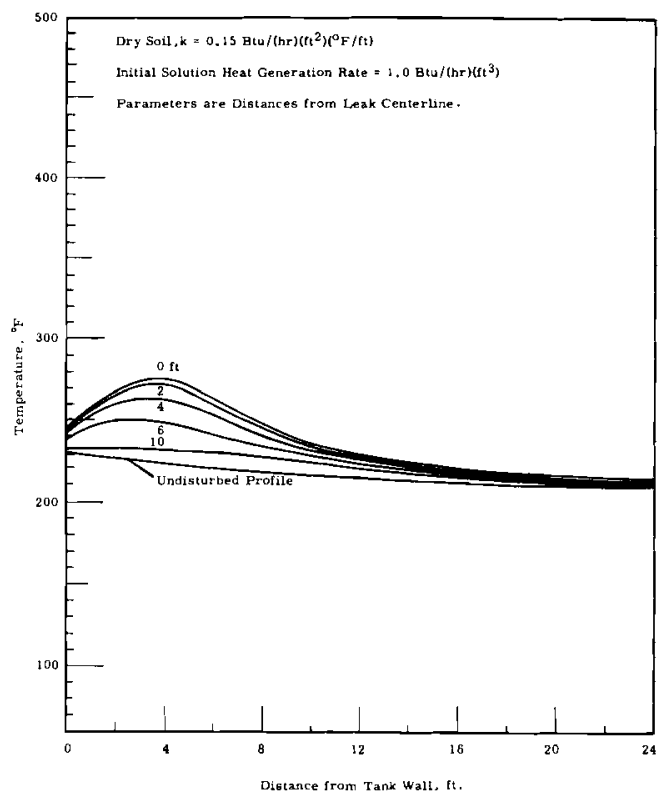

FIGURE 10 Temperatures in a 5000 gal Leak of Alkaline Supernate 
BNWL -181

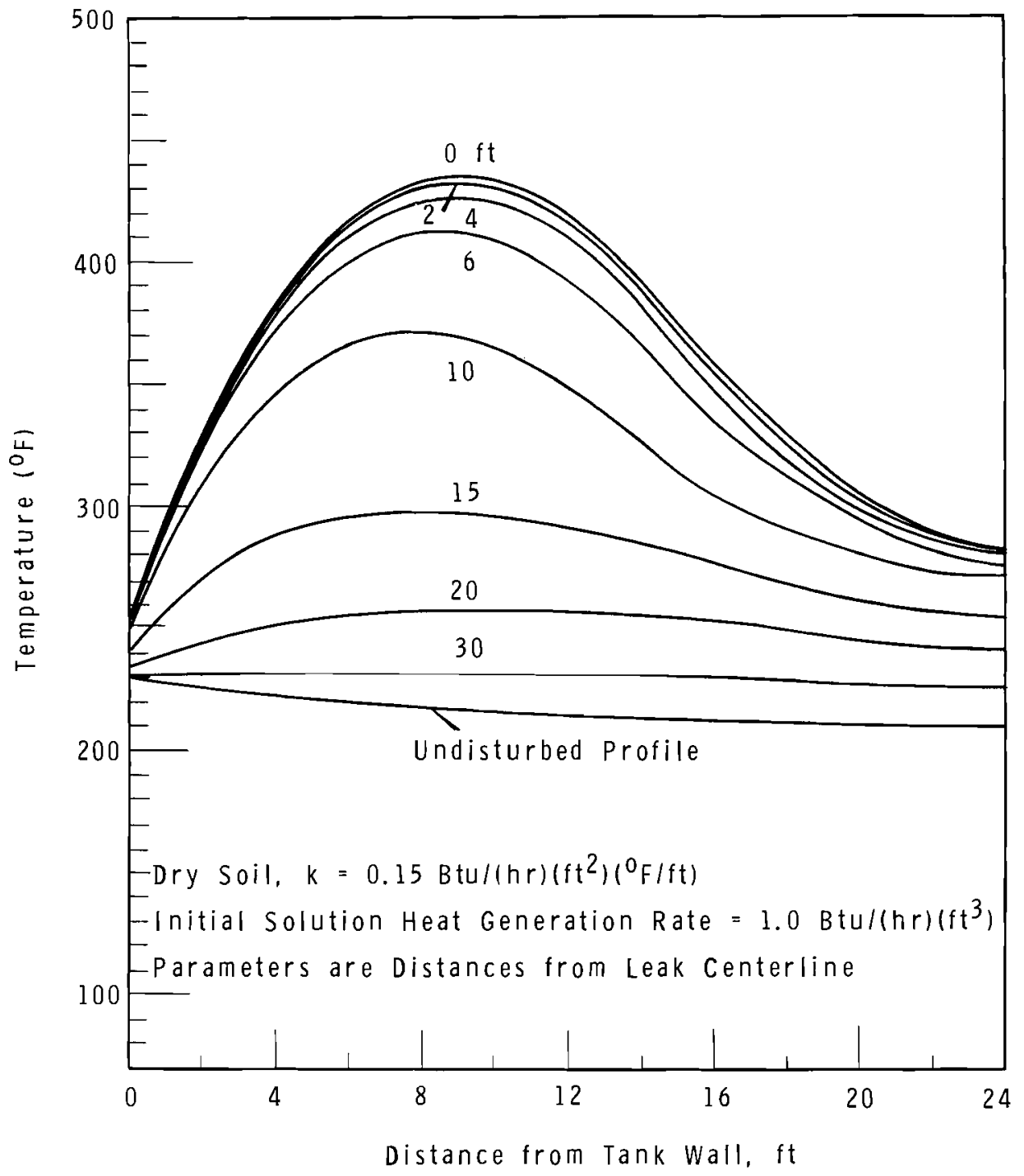

FIGURE 11 Temperatures in a 50,000 gal Leak of Alkaline Supernate

The possibility exists for monitoring soil temperatures over extended periods of time to determine background temperatures, and then interpreting sudden temperature rises as being leaks. With the information in Appendix B and the computer program GULP in Appendix $C$, it may be possible to estimate the approximate size and location of a leak from three noncolinear measuring points. One complicating factor may be the introduction of moisture into the soil by the leak. This would tend to raise the background temperature field but would reduce the field due to the heat generators in the leak itself. 


\section{ACKNOWLEDGMENTS}

This work was performed under the guidance of W. H. Swift, Manager, Engineering Development Unit, Chemical Development, Batte11e-Northwest.

The authors are indebted to A. G. Gibbs of the Reactor Physics Section of Battelle-Northwest for deriving the equations of temperature fields around hemispheroids.

The encouragement and cooperation of S. J. Beard and J. J. Shefcik of the Chemical Processing Department, HAPO, General Electric Company were decisive in the completion of the work.

We would also like to acknowledge the assistance of G. E. Lysher of the Chemical Development, Battelle-Northwest, in producing the original graphs and tables used in the report. 
APPENDIX A

SUMMARY OF EQUATIONS FOR TEMPERATURES NEAR LEAKS 


\section{APPENDIX A}

\section{GENERAL SOLUTION FOR TEMPERATURES NEAR LEAKS}

The method of derivation of these equations is given in HW-80848. (4) An excellent treatment of the application of potential theory to spheres and ellipsoids is given by MacMillan. (7)

The temperature rise near a hemispheroidal leak is given by

$$
\begin{aligned}
\mathrm{T}-\mathrm{T}_{\mathrm{O}}= & \frac{\mathrm{Sa}^{2}}{\mathrm{k}}\left\{\Lambda(\mathrm{b} / \mathrm{a}, \mathrm{c} / \mathrm{a}, \varepsilon)-\frac{1}{2 \pi}[\phi(b / a, c / a, \varepsilon)+\phi(b / a,-c / a, \varepsilon)\right. \\
& \left.\left.+\phi\left(b / a+m k / a k_{m}, c / a, \varepsilon\right)+\phi\left(b / a+m k / a k_{m},-c / a, \varepsilon\right)\right]\right\}
\end{aligned}
$$

where

$$
\phi(b / a, c / a, \varepsilon)=\int_{0}^{1} \int_{0}^{\varepsilon \sqrt{1-x^{2}}} \frac{d x d y d z}{\sqrt{(x+b / a)^{2}+\left(y-c / a^{2}\right)+z^{2}}}(A-2)
$$

The integration with respect to $z$ may be performed to give

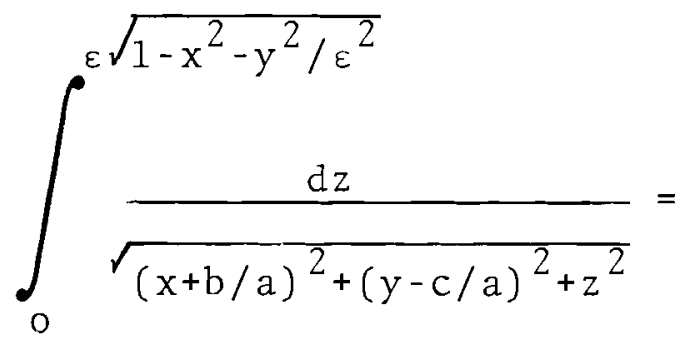

$$
=\log _{e}\left[\frac{\varepsilon \sqrt{1-x^{2}-y^{2} / \varepsilon^{2}}+\sqrt{(x+b / a)^{2}+(y-c / a)^{2}+\varepsilon^{2}\left(1-x^{2}-y^{2} / \varepsilon^{2}\right)}}{\sqrt{(x+b / a)^{2}+(y-c / a)^{2}}}\right]
$$


Further integration must be done numerically except for the special cases along the centerline of the leak for which definite integrals have been evaluated and are given later.

The function $\Lambda$, which represents the temperature field around a spheroid in an infinite medium, takes on a different form depending on the leak shape or whether the point of interest is inside or outside of the leak volume.

Hemispherical Leak, $\varepsilon=1$

Inside the leak volume $0 \leq \sqrt{b^{2} / a^{2}+c^{2} / a^{2}} \leq 1$

$$
\Lambda(b / a, c / a)=1 / 3+1 / 6\left(1-b^{2} / a^{2}-c^{2} / a^{2}\right)
$$

Outside the leak volume $\sqrt{b^{2} / a^{2}+c^{2} / a^{2}} \geq 1$

$$
\Lambda(b / a, c / a)=\frac{1}{3 \sqrt{b^{2} / a^{2}+c^{2} / a^{2}}}
$$

Prolate Hemispheroidal Leak, $\varepsilon<1$

$$
\begin{aligned}
\Lambda(b / a, c / a, \varepsilon)= & \frac{(1 / 2) \varepsilon^{2}}{\sqrt{1-\varepsilon^{2}}}\left[1+\frac{c^{2} / a^{2}-2 b^{2} / a^{2}}{2\left(1-\varepsilon^{2}\right)}\right] \sinh ^{-1} \sqrt{\frac{1-\varepsilon^{2}}{\varepsilon^{2}+k / a^{2}}} \\
& -(1 / 4) \varepsilon^{2} \frac{\sqrt{1+k / a^{2}}}{1-\varepsilon^{2}} \cdot \frac{c^{2} / a^{2}}{\varepsilon^{2}+k / a^{2}} \\
+ & \left(\frac{1 / 2) \varepsilon^{2} b^{2} / a^{2}}{2}\right) \sqrt{1+k / a^{2}}
\end{aligned}
$$

Inside the leak volume $0 \leq \sqrt{b^{2} / a^{2}+c^{2} / a^{2} \varepsilon^{2}} \leq 1$

$$
k / a^{2}=0
$$


Outside the leak volume $\sqrt{b^{2} / a^{2}+c^{2} / a^{2} \varepsilon^{2}} \geq 1$

$$
\begin{aligned}
\kappa / a^{2}= & \frac{b^{2} / a^{2}+c^{2} / a^{2}-\varepsilon^{2}-1}{2} \cdot \\
& \left(1 \pm \sqrt{1+4 \frac{c^{2} / a^{2}+\varepsilon^{2}\left(b^{2} / a^{2}-1\right)}{\left(b^{2} / a^{2}+c^{2} / a^{2}-\varepsilon^{2}-1\right)^{2}}}\right)
\end{aligned}
$$

The negative sign in Equation (8) is used only when $\left(1+\varepsilon^{2}\right)>\left(b^{2} / a^{2}+c^{2} / a^{2}\right)$.

Oblate Hemispheroidal Leak, $\varepsilon>1$

$$
\begin{aligned}
\Lambda(b / a, c / a, \varepsilon) & =\frac{(1 / 2) \varepsilon^{2}}{\sqrt{\varepsilon^{2}-1}}\left[1-\frac{c^{2} / a^{2}-2 b^{2} / a^{2}}{2\left(\varepsilon^{2}-1\right)}\right] \sin ^{-1} \sqrt{\frac{\varepsilon^{2}-1}{\varepsilon^{2}+k / a^{2}}} \\
& +(1 / 4) \frac{\varepsilon^{2} \sqrt{1+k / a^{2}}}{\varepsilon^{2}-1} \cdot \frac{c^{2} / a^{2}}{\varepsilon^{2}+k / a^{2}} \\
& -(1 / 2) \frac{\varepsilon^{2} b^{2} / a^{2}}{\left(\varepsilon^{2}-1\right) \sqrt{1+k / a^{2}}}
\end{aligned}
$$

Equations (7) and (8) also define $\mathrm{k} / \mathrm{a}^{2}$ for the oblate hemispheroidal leak.

TEMPERATURES ALONG THE AXES OF LEAKS

The following results were derived by A. G. Gibbs of the Reactor Physics Section. Hemispherical Leak, $\varepsilon=1$

Analytical relationships showing the temperature rises above background temperatures along the axis of hemispherical leaks are given below. 
At the tank wall, $b=0$,

$\mathrm{T}(\mathrm{b} / \mathrm{a}=0)-\mathrm{T}_{0}=\frac{\mathrm{Sa}^{2}}{4 \mathrm{k}}\left[\psi_{1}(0)-\Omega(\beta / \mathrm{a})\right]$

$$
=\frac{\mathrm{Sa}^{2}}{\mathrm{k}}\left[\frac{1}{6}\left(\frac{\mathrm{mk}}{\mathrm{ak}}\right)^{2}+\frac{1-\left[1+\left(\mathrm{mk} / \mathrm{ak}_{\mathrm{m}}\right)^{2}\right]^{3 / 2}}{6 \mathrm{mk} / \mathrm{ak} \mathrm{m}_{\mathrm{m}}}\right] \text {. }
$$

Inside the leak volume, $0 \leq b \leq a$,

$\mathrm{T}(\mathrm{b} / \mathrm{a})-\mathrm{T}_{0}=\frac{\mathrm{Sa}^{2}}{4 \mathrm{~K}}\left[\psi_{1}(\mathrm{~b} / \mathrm{a})-\Omega(B / \mathrm{a})\right]$.

Outside the leak volume, $b \geq a$,

$\mathrm{T}(\mathrm{b} / \mathrm{a})-\mathrm{T}_{0}=\frac{S \mathrm{a}^{2}}{4 \mathrm{k}}\left[\psi_{2}(\mathrm{~b} / \mathrm{a})-\Omega(\beta / \mathrm{a})\right]$

where

$$
\begin{aligned}
& \beta=b+m k / k_{m} \\
& \Omega(\beta / a)=1+\frac{2 \beta^{2}}{3 a^{2}}-\frac{\left(1+\beta^{2} / a^{2}\right)^{3 / 2}-1}{3 \beta / 2 a} \\
& \psi_{1}(0)=1 \\
& \psi_{1}(b / a)=1-\frac{4 b^{2}}{3 a^{2}}+\frac{\left(1+b^{2} / a^{2}\right)^{3 / 2}-1}{3 b / 2 a} \\
& \psi_{2}(b / a)=-1-\frac{2 b^{2}}{3 a^{2}}+\frac{\left(1+b^{2} / a^{2}\right) 3 / 2+1}{3 b / 2 a} .
\end{aligned}
$$


BNWL-181

Prolate Hemispheroidal Leak, $\varepsilon<1$

The following substitutions may be made in Equations (10), (11), and (12):

$\Omega(\beta / a)=A(\beta / a, \varepsilon)+\frac{B(\beta / a, \varepsilon)}{\sqrt{1-\varepsilon^{2}}} \log e\left[\frac{\beta / a+1-\varepsilon^{2}+(1+\beta / a) \sqrt{1-\varepsilon^{2}}}{\beta / a+\sqrt{\left(1-\varepsilon^{2}\right)\left(\varepsilon^{2}+\beta^{2} / a^{2}\right)}}\right]$

where

$$
\begin{gathered}
A(\beta / a, \varepsilon)=\left[(\beta / a)(\beta / a+1) /\left(1-\varepsilon^{2}\right)\right]-\beta / a-\left[(\beta / a) \sqrt{\varepsilon^{2}+\beta / a^{2}} /\left(1-\varepsilon^{2}\right)\right] \\
B(\beta / a, \varepsilon)=\varepsilon^{2}-\left[\left(\beta^{2} / a^{2}\right) \varepsilon^{2} /\left(1-\varepsilon^{2}\right)\right] . \\
\text { At the point of leakage, b=0, } \\
\psi_{1}(0)=\frac{\varepsilon^{2}}{\sqrt{1-\varepsilon^{2}}} \log _{e}\left(\frac{1-\varepsilon^{2}+\sqrt{1-\varepsilon^{2}}}{\varepsilon \sqrt{1-\varepsilon^{2}}}\right) .
\end{gathered}
$$

Inside the leak volume, $0 \leq b \leq a$,$$
\psi_{1}(b / a)=G(b / a, \varepsilon)+\frac{B(b / a, \varepsilon)}{\sqrt{1-\varepsilon^{2}}} \log e\left[\frac{b / a-1+\varepsilon^{2}-(1-b / a) \sqrt{1-\varepsilon^{2}}}{b / a-\sqrt{\left(1-\varepsilon^{2}\right)\left(\varepsilon^{2}+b^{2} / a^{2}\right)}}\right]
$$

where

$G(b / a, \varepsilon)=\left[(b / a)(b / a-1) /\left(1-\varepsilon^{2}\right)\right]+b / a-2 b^{2} / a^{2}+(b / a) \sqrt{\varepsilon^{2}+b^{2} / a^{2} /\left(1-\varepsilon^{2}\right)}$.

Outside the leak volume, $b \geq a$,

$$
\psi_{2}(b / a)=H(b / a, \varepsilon)+\frac{B(b / a, \varepsilon)}{\sqrt{1-\varepsilon^{2}}} \log e\left[\frac{b / a-1+\varepsilon^{2}+(1-b / a) \sqrt{1-\varepsilon^{2}}}{b / a-\sqrt{\left(1-\varepsilon^{2}\right)\left(\varepsilon^{2}+b^{2} / a^{2}\right)}}\right]
$$

where

$H(b / a, \varepsilon)=\left[(b / a)(b / a-1) /\left(\varepsilon^{2}-1\right)\right]-b / a+\left[(b / a) \sqrt{\varepsilon^{2}+b^{2} / a^{2} /\left(1-\varepsilon^{2}\right)}\right]$. 
Oblate Hemispheroidal Leak, $\varepsilon>1$

The following substitutions may be made in Equations (10), (11), and (12),

$\Omega(\beta / a)=A(\beta / a, \varepsilon)-\frac{B(\beta / a, \varepsilon)}{\sqrt{\varepsilon^{2}-1}}\left\{\sin ^{-1}\left[\frac{-\beta / a}{D(\beta / a, \varepsilon)}\right]+\sin ^{-1}\left[\frac{\beta / a+1-\varepsilon^{2}}{D(\beta / a, \varepsilon)}\right]\right\}$

where

$D(\beta / a, \varepsilon)=\sqrt{\beta^{2} / a^{2}-\left(1-\varepsilon^{2}\right)\left(\varepsilon^{2}+\beta^{2} / a^{2}\right)}$

At the point of leakage, $b=0$,

$\psi_{1}(0)=\frac{\varepsilon^{2}}{\sqrt{\varepsilon^{2}-1}} \sin ^{-1}\left(\frac{\sqrt{\varepsilon^{2}-1}}{-\varepsilon}\right)$

Inside the leak volume, $0 \leq b \leq a$,

$\psi_{1}(b / a)=G(b / a, \varepsilon)+\frac{B(b / a, \varepsilon)}{\sqrt{\varepsilon^{2}-1}}\left\{\sin ^{-1}\left[\frac{-b / a}{D(b / a, \varepsilon)}\right]-\sin ^{-1}\left[\frac{-b / a+1-\varepsilon^{2}}{D(b / a, \varepsilon)}\right]\right\}$.

$(A-29)$

Outside the leak volume, $b \geq a$,

$\psi_{2}(b / a)=\psi_{1}(b / a)-G(b / a, \varepsilon)+H(b / a, \varepsilon)$.

$(A-30)$ 


\section{APPENDIX B}

TEMPERATURE MAPS AROUND HEMISPHERICAL LEAKS 


\section{APPENDIX B}

Temperature maps for the cases 1 isted in Table B-I are given in Appendix B. The temperature rises in the leaks may be adjusted for initial solution heat generation rates different from unity by a simple ratio.

TABLE B-1

TEMPERATURE RISES IN HEMISPHERICAL UNDERGROUND TANK LEAKS CALCULATED BY GULP

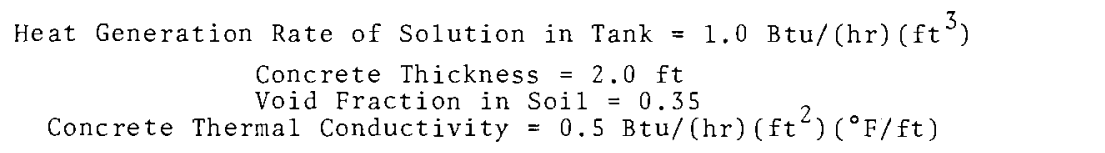

\begin{tabular}{|c|c|c|c|c|c|c|}
\hline $\begin{array}{l}\text { Case } \\
\text { No. }\end{array}$ & $\begin{array}{c}\text { Leak } \\
\text { Volume, } \\
\text { gal } \\
\end{array}$ & \begin{tabular}{l}
\multicolumn{1}{c}{ Fission } \\
Product \\
Distribution \\
Coefficient \\
\end{tabular} & $\begin{array}{l}\text { Soil Thermal } \\
\text { Conductivity }\end{array}$ & $\begin{array}{c}\text { Leak } \\
\text { Radius, } f \underline{t}\end{array}$ & $\begin{array}{l}\text { Maximum Wa } 11 \\
\text { Temperature, }{ }^{\circ} \mathrm{F}\end{array}$ & $\begin{array}{l}\text { Maximum Soil } \\
\text { Temperature, }{ }^{\circ} \mathrm{F}\end{array}$ \\
\hline & V & $\mathrm{K}_{\mathrm{D}}$ & k & a & $\mathrm{T}-\mathrm{T}_{0}^{*}$ & $T-T_{0}^{*}$ \\
\hline $\begin{array}{l}1 \\
2 \\
3 \\
4\end{array}$ & $\begin{array}{l}1,000 \\
1,000 \\
1,000 \\
1,000\end{array}$ & $\begin{array}{l}0 \\
0 \\
0.6 \\
0.6\end{array}$ & $\begin{array}{l}0.15 \\
0.6 \\
0.15 \\
0.6\end{array}$ & $\begin{array}{l}5.67 \\
5.67 \\
4.07 \\
4.07\end{array}$ & $\begin{array}{ll}3.5 & (1.9) \\
2.4 & (1.5) \\
6.4 & (3.5) \\
3.9 & (2.7)\end{array}$ & $\begin{aligned} 11.8 & (11.2) \\
3.7 & (3.2) \\
17.9 & (16.4) \\
5.8 & (5.0)\end{aligned}$ \\
\hline $\begin{array}{l}5 \\
6 \\
7 \\
8\end{array}$ & $\begin{array}{l}5,000 \\
5,000 \\
5,000 \\
5,000\end{array}$ & $\begin{array}{l}0 \\
0 \\
0.6 \\
0.6\end{array}$ & $\begin{array}{l}0.15 \\
0.6 \\
0.15 \\
0.6\end{array}$ & $\begin{array}{l}9.70 \\
9.70 \\
6.95 \\
6.95\end{array}$ & $\begin{aligned} 6.2 & (3.3) \\
4.9 & (2.9) \\
11.8 & (6.2) \\
8.6 & (5.3)\end{aligned}$ & $\begin{array}{ll}34.1 & (32.6) \\
10.3 & (9.2) \\
49.7 & (47.4) \\
15.0 & (13.5)\end{array}$ \\
\hline $\begin{array}{r}9 \\
10 \\
11 \\
12\end{array}$ & $\begin{array}{l}10,000 \\
10,000 \\
10,000 \\
10,000\end{array}$ & $\begin{array}{l}0 \\
0 \\
0.6 \\
0.6\end{array}$ & $\begin{array}{l}0.15 \\
0.6 \\
0.15 \\
0.6\end{array}$ & $\begin{array}{r}12.22 \\
12.22 \\
8.76 \\
8.76\end{array}$ & $\begin{aligned} 8.0 & (4.1) \\
6.6 & (3.8) \\
15.2 & (8.0) \\
11.7 & (7.0)\end{aligned}$ & $\begin{array}{l}54.1(52.6) \\
15.7(14.3) \\
77.3(74.0) \\
23.2(20.8)\end{array}$ \\
\hline $\begin{array}{l}13 \\
14 \\
15 \\
16\end{array}$ & $\begin{array}{l}25,000 \\
25,000 \\
25,000 \\
25,000\end{array}$ & $\begin{array}{l}0 \\
0 \\
0.6 \\
0.6\end{array}$ & $\begin{array}{l}0.15 \\
0.6 \\
0.15 \\
0.6\end{array}$ & $\begin{array}{l}16.58 \\
16.58 \\
11.89 \\
11.89\end{array}$ & $\begin{aligned} 11.0 & (5.7) \\
9.6 & (5.3) \\
21.1 & (10.9) \\
17.4 & (9.9)\end{aligned}$ & $\begin{aligned} 98.3 & (96.0) \\
27.7 & (25.7) \\
139.4 & (134.9) \\
40.5 & (37.0)\end{aligned}$ \\
\hline $\begin{array}{l}17 \\
18 \\
19 \\
20\end{array}$ & $\begin{array}{l}50,000 \\
50,000 \\
50,000 \\
50,000\end{array}$ & $\begin{array}{l}0 \\
0 \\
0.6 \\
0.6\end{array}$ & $\begin{array}{l}0.15 \\
0.6 \\
0.15 \\
0.6\end{array}$ & $\begin{array}{l}20.89 \\
20.89 \\
14.98 \\
14.98\end{array}$ & $\begin{array}{ll}14.0 & (7.2) \\
12.6 & (6.8) \\
26.9 & (13.9) \\
23.1 & (12.8)\end{array}$ & $\begin{aligned} 152.1 & (149.6) \\
41.7 & (39.3) \\
218.0 & (209.4) \\
62.0 & (57.1)\end{aligned}$ \\
\hline $\begin{array}{l}21 \\
22 \\
23 \\
24\end{array}$ & $\begin{array}{l}100,000 \\
100,000 \\
100,000 \\
100,000\end{array}$ & $\begin{array}{l}0 \\
0 \\
0.6 \\
0.6\end{array}$ & $\begin{array}{l}0.15 \\
0.6 \\
0.15 \\
0.6\end{array}$ & $\begin{array}{l}26.32 \\
26.32 \\
18.87 \\
18.87\end{array}$ & $\begin{array}{ll}17.7 & (9.1) \\
16.3 & (8.7) \\
34.1 & (17.5) \\
30.3 & (16.5)\end{array}$ & $\begin{aligned} 241.8 & (237.9) \\
66.0 & (62.5) \\
325.0 & (329.6) \\
95.2 & (88.4)\end{aligned}$ \\
\hline $\begin{array}{l}25 \\
26\end{array}$ & $\begin{array}{l}100 \\
100\end{array}$ & $\begin{array}{l}500 \\
500\end{array}$ & $\begin{array}{l}0.15 \\
0.6\end{array}$ & $\begin{array}{l}0.23 \\
0.23\end{array}$ & $\begin{array}{l}40.0(35.4) \\
11.0(10.7)\end{array}$ & $\begin{array}{l}-- \\
--\end{array}$ \\
\hline $\begin{array}{l}27 \\
28\end{array}$ & $\begin{array}{l}500 \\
500\end{array}$ & $\begin{array}{l}500 \\
500\end{array}$ & $\begin{array}{l}0.15 \\
0.6\end{array}$ & $\begin{array}{l}0.40 \\
0.40\end{array}$ & $\begin{aligned} 107.1 & (87.8) \\
31.5 & (29.8)\end{aligned}$ & -- \\
\hline $\begin{array}{l}29 \\
30\end{array}$ & $\begin{array}{l}1,000 \\
1,000\end{array}$ & $\begin{array}{l}500 \\
500\end{array}$ & $\begin{array}{l}0.15 \\
0.6\end{array}$ & $\begin{array}{l}0.50 \\
0.50\end{array}$ & $\begin{aligned} 161.2 & (126.8) \\
49.3 & (46.0)\end{aligned}$ & $\begin{array}{l}-- \\
--\end{array}$ \\
\hline $\begin{array}{l}31 \\
32\end{array}$ & $\begin{array}{l}5,000 \\
5,000\end{array}$ & $\begin{array}{l}500 \\
500\end{array}$ & $\begin{array}{l}0.15 \\
0.6\end{array}$ & $\begin{array}{l}0.86 \\
0.86\end{array}$ & $\begin{array}{l}395.9(279.3) \\
137.2(122.4)\end{array}$ & $\begin{array}{l}-- \\
--\end{array}$ \\
\hline $\begin{array}{l}37 \\
38\end{array}$ & $\begin{array}{l}10,000 \\
10,000\end{array}$ & $\begin{array}{l}500 \\
500\end{array}$ & $\begin{array}{l}0.15 \\
0.6\end{array}$ & $\begin{array}{l}1.08 \\
1.08\end{array}$ & $\begin{array}{l}568.5(382.1) \\
211.3(183.5)\end{array}$ & $\begin{array}{cc}679.1 & (606.5) \\
- & (190.1)\end{array}$ \\
\hline $\begin{array}{l}33 \\
34\end{array}$ & $\begin{array}{l}25,000 \\
25,000\end{array}$ & $\begin{array}{l}500 \\
500\end{array}$ & $\begin{array}{l}0.15 \\
0.6\end{array}$ & $\begin{array}{l}1.47 \\
1.47\end{array}$ & $\begin{array}{ll}894.3 & (566.1) \\
369.6 & (307.1)\end{array}$ & $\begin{aligned} 1437.1 & (1287.0) \\
444.3 & (403.8)\end{aligned}$ \\
\hline $\begin{array}{l}35 \\
36\end{array}$ & $\begin{array}{l}50,000 \\
50,000\end{array}$ & $\begin{array}{l}500 \\
500\end{array}$ & $\begin{array}{l}0.15 \\
0.6\end{array}$ & $\begin{array}{l}1.85 \\
1.85\end{array}$ & $\begin{array}{r}1236.3(751.6) \\
558.2(445.9)\end{array}$ & $\begin{aligned} 2258.1 & (2008.4) \\
717.4 & (642.7)\end{aligned}$ \\
\hline
\end{tabular}




\section{TEMPERATURE MAPS AROUND HEMISPHERICAL LEAKS}

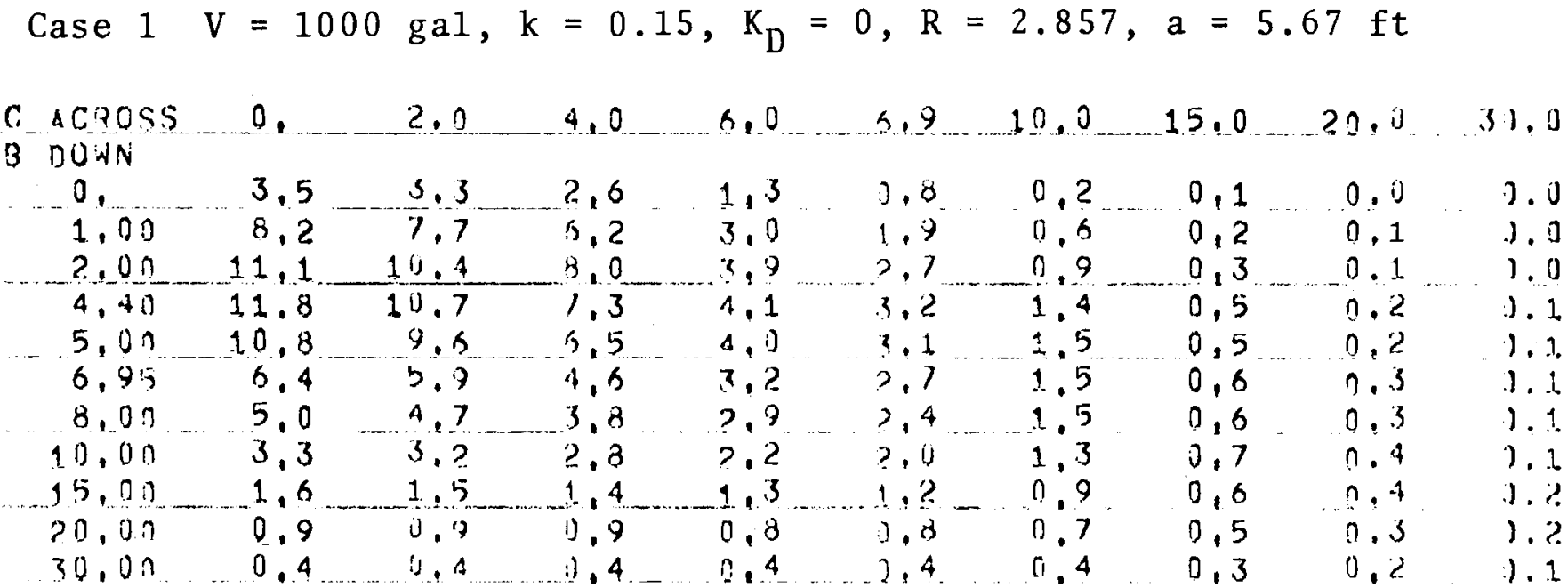

Case $2 \mathrm{~V}=1000 \mathrm{gal}, \mathrm{k}=0.6, \mathrm{~K}_{\mathrm{D}}=0, \mathrm{R}=2.857, \mathrm{a}=5.67 \mathrm{ft}$

\begin{tabular}{|c|c|c|c|c|c|c|c|c|c|}
\hline \multirow{2}{*}{\multicolumn{10}{|c|}{$\begin{array}{l}C \text { ACZOCS } \\
\text { DOdN }\end{array}$}} \\
\hline & & & & & & & & & \\
\hline 0 & 2.4 & 2.? & 1.8 & 1.1 & o & 0,3 & 0,1 & 1.0 & 1.0 \\
\hline 1.00 & 3,3 & 3.1 & 2.5 & 1.4 & 1.0 & 0.4 & 0,1 & 0.1 & 1.0 \\
\hline 2.01 & 3.7 & 5.5 & $? .8$ & 1.6 & 1,1 & 0,5 & $0, ?$ & 3.1 & 1.4 \\
\hline 4.40 & 3,6 & $3 . ?$ & 2,3 & 1,4 & 1,2 & 0,6 & 0,2 & ]. 1 & 1.0 \\
\hline $5.0 ?$ & $3 . ?$ & 2.9 & 2,1 & 1.4 & 1.1 & 0.6 & 0,2 & 0.1 & 1.0 \\
\hline 6.96 & 2,0 & 1.7 & 1. .5 & 1.1 & 1.0 & 0.5 & 0,3 & 0.1 & 1.0 \\
\hline 8.00 & 1,6 & 1.5 & 1.3 & 1.0 & 3.3 & 0.5 & 0,3 & 0.1 & 1.1. \\
\hline 10,00 & 1,1 & 1.1 & i) .9 & 0.8 &., 1 & 0.5 & 0,3 & 0.1 & 1.1 \\
\hline 15,011 & 0,5 & 0.5 & 3,5 & 0,5 & 2.4 & i) .3 & 0,2 & 0.1 & 1,1, \\
\hline 20,00 & 0.3 & 0.3 & i), 3 & 6,3 & 2,3 & i), 2 & 0,2 & 0.2 & 1.1. \\
\hline 30,00 & 0,2 & 1).? & 1,1 & $n, 1$ & 9,1 & 0.1 & 0,1 & 0.1 & 1,1 \\
\hline
\end{tabular}

Case $3 \mathrm{~V}=1000 \mathrm{gal}, \mathrm{k}=0.6, \mathrm{~K}_{\mathrm{D}}=0.6, \mathrm{R}=1.053, \mathrm{a}=4.07 \mathrm{ft}$

\begin{tabular}{|c|c|c|c|c|c|c|c|c|c|}
\hline $\begin{array}{l}\text { icooss } \\
\text { nOMN }\end{array}$ & 0 . & $?, 0$ & 4.0 & $-6,0$ & -6.9. & 10.0 & 15,0 & 20,0 & 30.0 \\
\hline 0 & 6.4 & 5.7 & 3,0 & 0.9 & 0,5 & 0.2 & 0.1 & 0.0 & 0.0 \\
\hline 1.00 & 14.5 & 12.7 & 3.5 & 2,1 & 1.4 & 0.5 & 0.1 & 0.1 & 0.0 \\
\hline 2.00 & 17.9 & 15.3 & 7.5 & 2,9 & 2.0 & 0.7 & 0.2 & 0.1 & 0.0 \\
\hline $4.4 \pi$ & 11.6 & 9.4 & 5.7 & 3,2 & 2.4 & 1.1 & 0,4 & 0.2 & 0,1 \\
\hline 5.00 & 9.3 & 7.3 & 5.1 & 3,1 & $? .4$ & 1.1 & 0.4 & 0.2 & 0.1 \\
\hline 6.95 & 5.? & 4.7 & 3.6 & 2.5 & 2.1 & 1.2 & 0.5 & 0.2 & 0.1 \\
\hline 8.00 & 4.0 & 3.7 & 3.0 & $? .2$ & 1,9 & 1.1 & 0.5 & 0.2 & 0.1 \\
\hline $10.0 n$ & 2.6 & 2.5 & 2.? & 1.8 & 1.6 & 1.0 & 0.5 & 0.3 & 0.1 \\
\hline 15.00 & 1.2 & $1 . ?$ & 1.1 & 1.0 & 0.9 & 0.7 & 0.5 & 0.3 & 0.1 \\
\hline 20.00 & 0.7 & 0.7 & 0.7 & 0.6 & 0.6 & 0.5 & 0,4 & 0.3 & 0.1 \\
\hline
\end{tabular}


Case $4 \mathrm{~V}=1000 \mathrm{gal}, \mathrm{k}=0.6, \mathrm{~K}_{\mathrm{D}}=0.6, \mathrm{R}=1.053, \mathrm{a}=4.07 \mathrm{ft}$

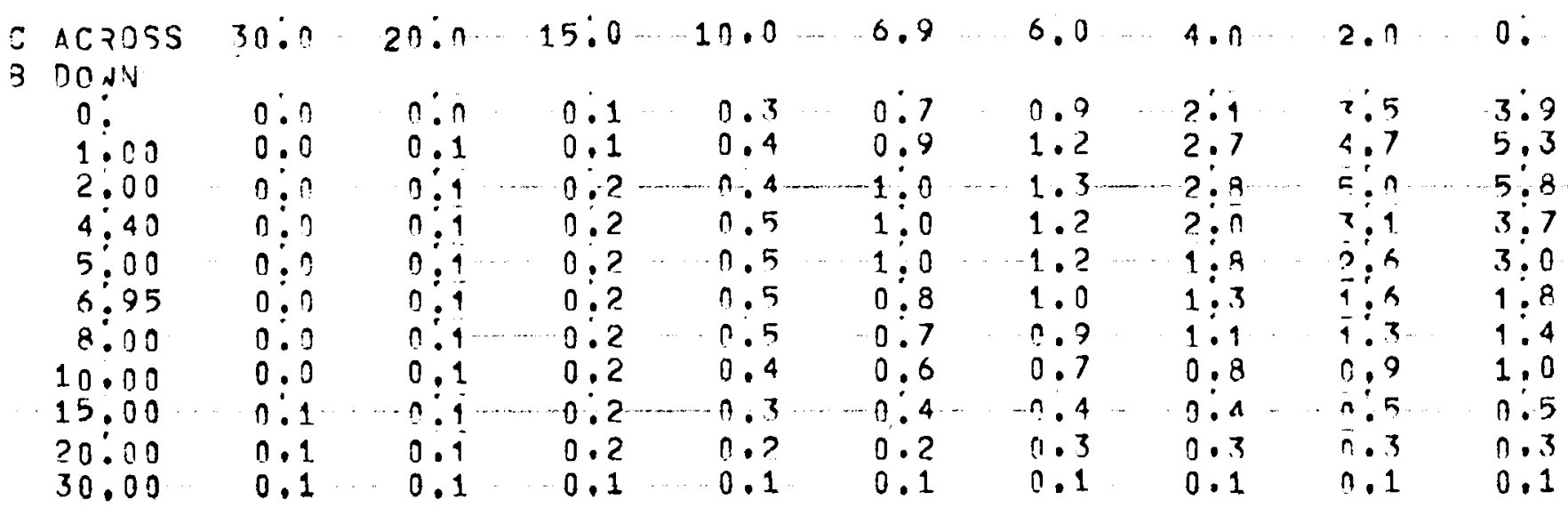

Case $5 \mathrm{~V}=5000 \mathrm{gal}, \mathrm{k}=0.15, \mathrm{~K}_{\mathrm{D}}=0, \mathrm{R}=2.857, \mathrm{a}=9.70 \mathrm{ft}$

\begin{tabular}{|c|c|c|c|c|c|c|c|c|c|}
\hline $\begin{array}{l}\text { ACROSS } \\
\text { DOWN }\end{array}$ & 30.0 & 20.0 & 15.0 & 10.0 & $6: 9$ & S. 0 & 4.0 & 2.0 & 0 . \\
\hline $\begin{array}{l}0.00 \\
1.00 \\
2.00\end{array}$ & $\begin{array}{l}0.1 \\
0.2 \\
0.3\end{array}$ & $\begin{array}{l}0.2 \\
0.6 \\
1.0\end{array}$ & $\begin{array}{l}0.6 \\
1.5 \\
2.4\end{array}$ & $\begin{array}{l}2.4 \\
6.0 \\
8.7\end{array}$ & $\begin{array}{r}4.8 \\
11.8 \\
16.9\end{array}$ & $\begin{array}{r}5.2 \\
12.8 \\
18.6\end{array}$ & $\begin{array}{r}5.8 \\
14.4 \\
21.1\end{array}$ & $\begin{array}{r}6.1 \\
15.3 \\
22.5\end{array}$ & $\begin{array}{r}6.2 \\
15.6 \\
22.9\end{array}$ \\
\hline $\begin{array}{r}4.40 \\
5: 00 \\
6.95 \\
8: 00 \\
10.00\end{array}$ & $\begin{array}{l}0.5 \\
0.6 \\
0.8 \\
0.8 \\
1.0\end{array}$ & $\begin{array}{l}1 \cdot 8 \\
1 \cdot 9 \\
2 \cdot 4 \\
2 \cdot 8 \\
2.8\end{array}$ & $\begin{array}{l}4.1 \\
4.3 \\
5.0 \\
5.2 \\
5.2\end{array}$ & $\begin{array}{l}11 . ? \\
12.1 \\
12 . ? \\
11.5 \\
10.3\end{array}$ & $\begin{array}{l:l}22 & 9 \\
23 & 1 \\
20 & 9 \\
18: 8 \\
15.2\end{array}$ & $\begin{array}{l}25: 6 \\
26: 0 \\
24: 3 \\
21: 7 \\
17.0\end{array}$ & $\begin{array}{l:}29 \\
30: 6 \\
29: 8 \\
27.1 \\
20.6\end{array}$ & $\begin{array}{l}32: ? \\
33: ? \\
33: 0 \\
30: 9 \\
23.3\end{array}$ & $\begin{array}{l}33.0 \\
34.1 \\
34.0 \\
31.9 \\
24.4\end{array}$ \\
\hline $\begin{array}{l}15.00 \\
20.00 \\
30.00\end{array}$ & $\begin{array}{l}1.2 \\
1.3 \\
1.2\end{array}$ & $\begin{array}{l}2.9 \\
2.6 \\
1.9\end{array}$ & $\begin{array}{l}4.6 \\
3.7 \\
2.3\end{array}$ & $\begin{array}{l}7.3 \\
5.1 \\
2.7\end{array}$ & $\begin{array}{l}9.2 \\
5.9 \\
2.9\end{array}$ & $\begin{array}{l}9.7 \\
6: 1 \\
3.0\end{array}$ & $\begin{array}{r}10.8 \\
6.5 \\
3.1\end{array}$ & $\begin{array}{r}11: 5 \\
6: 8 \\
3.1\end{array}$ & $\begin{array}{r}11.8 \\
6.9 \\
3.2\end{array}$ \\
\hline
\end{tabular}

Case $6 \mathrm{~V}=5000 \mathrm{gal}, \mathrm{k}=0.6, \mathrm{~K}_{\mathrm{D}}=0, \mathrm{R}=2.857, \mathrm{a}=9.70 \mathrm{ft}$

\begin{tabular}{|c|c|c|c|c|c|c|c|c|c|}
\hline $\begin{array}{l}\text { ACROSS } \\
\text { DOWN }\end{array}$ & 30.0 & 20.0 & 15.0 & 10.0 & $6: 9$ & 5.0 & 4.0 & $2 . n$ & 0 . \\
\hline $\begin{array}{l}0.00 \\
1.00 \\
2.00\end{array}$ & $\begin{array}{l}0.1 \\
0.1 \\
0.2\end{array}$ & $\begin{array}{l}0.3 \\
0.4 \\
0.5\end{array}$ & $\begin{array}{l}0.7 \\
1.0 \\
1.2\end{array}$ & $\begin{array}{l}2.2 \\
2.9 \\
3.5\end{array}$ & $\begin{array}{l}3.7 \\
5.1 \\
6.1\end{array}$ & $\begin{array}{l}4.0 \\
5.6 \\
6.7\end{array}$ & $\begin{array}{l}4.6 \\
6.3 \\
7.6\end{array}$ & $\begin{array}{l}4.8 \\
6.7 \\
8.1\end{array}$ & $\begin{array}{l}4.9 \\
6.8 \\
8.3\end{array}$ \\
\hline $\begin{array}{l}4.40 \\
5.00 \\
6.95\end{array}$ & $\begin{array}{l}0.2 \\
0.3 \\
0.3\end{array}$ & $\begin{array}{l}0.8 \\
0.8 \\
0.9\end{array}$ & $\begin{array}{l}1.6 \\
1.7 \\
1.8\end{array}$ & $\begin{array}{l}4.1 \\
4.1 \\
3.9\end{array}$ & $\begin{array}{l}7: 2 \\
7: 1 \\
6: 3\end{array}$ & $\begin{array}{l}7.9 \\
8.0 \\
7.3\end{array}$ & $\begin{array}{l}9.2 \\
9.3 \\
8.7\end{array}$ & $\begin{array}{r}9.0 \\
10.0 \\
9.6\end{array}$ & $\begin{array}{r}10.1 \\
10.3 \\
9.9\end{array}$ \\
\hline $\begin{array}{r}8.00 \\
10.00\end{array}$ & $\begin{array}{l}0.3 \\
0.4\end{array}$ & $\begin{array}{l}1.0 \\
1.0\end{array}$ & $\begin{array}{l}1.8 \\
1.8\end{array}$ & $\begin{array}{l}3.7 \\
3.3\end{array}$ & $\begin{array}{l}5: 7 \\
4: 6\end{array}$ & $\begin{array}{l}6.5 \\
5.1\end{array}$ & $\begin{array}{l}8.0 \\
6.1\end{array}$ & $\begin{array}{l}8.9 \\
6.8\end{array}$ & $\begin{array}{l}9.2 \\
7.1\end{array}$ \\
\hline $\begin{array}{l}15: 00 \\
20: 00 \\
30.00\end{array}$ & $\begin{array}{l}0.4 \\
0.5 \\
0.4\end{array}$ & $\begin{array}{l}1: n \\
0.9 \\
0.6\end{array}$ & $\begin{array}{l}1.5 \\
1.2 \\
0.8\end{array}$ & $\begin{array}{l}2.3 \\
1.6 \\
0.9\end{array}$ & $\begin{array}{l}2: 8 \\
1: 9 \\
1: 0\end{array}$ & $\begin{array}{l}3: 0 \\
1: 9 \\
1: 0\end{array}$ & $\begin{array}{l:l}3.3 \\
2: 0 \\
1: 0\end{array}$ & $\begin{array}{l}3: 5 \\
2: 1 \\
1: 0\end{array}$ & $\begin{array}{l}3: 6 \\
2: 1 \\
1: 0\end{array}$ \\
\hline
\end{tabular}


Case $7 \mathrm{~V}=5000 \mathrm{gal}, \mathrm{k}=0.15, \mathrm{~K}_{\mathrm{D}}=0.6, \mathrm{R}=1.053, \mathrm{a}=6.95 \mathrm{ft}$

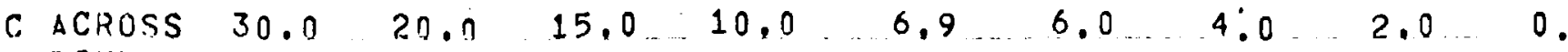
B DOWN

$\begin{array}{rrrrrrrrrr}0 . & 0.0 & 0.2 & 0.4 & 1.5 & 5.2 & 7.4 & 10.0 & 11.4 & 11.8 \\ 1.00 & 0.1 & 0.5 & 1.1 & 3.8 & 12.4 & 17.4 & 24.2 & 27.6 & 28.6 \\ 2.00 & 0.2 & 0.7 & 1.7 & 5.8 & 1.7 .7 & 23.4 & 33.3 & 38.5 & 40.2 \\ 4.40 & 0.4 & 1.3 & 2.9 & 8.5 & 18.9 & 24.6 & 38.6 & 47.0 & 49.7 \\ 5.00 & 0.4 & 1.4 & 3.2 & 8.8 & 18.4 & 23.4 & 36.8 & 45.7 & 48.6 \\ 6.95 & 0.6 & 1.2 & 3.7 & 8.9 & 15.9 & 19.0 & 26.5 & 3.3 .7 & 36.8 \\ 8.00 & 0.6 & 1.9 & 3.8 & 8.6 & 14.4 & 16.7 & 22.1 & 26.0 & 28.8 \\ 10.00 & 0.7 & 2.1 & 3.9 & 7.8 & 11.7 & 13.1 & 16.1 & 18.4 & 19.3 \\ 15.00 & 0.9 & 2.2 & 3.5 & 5.5 & 7.0 & 7.5 & 8.3 & 8.9 & 9.1 \\ 20.00 & 1.0 & 2.0 & 2.8 & 3.9 & 4.5 & 4.7 & 5.0 & 5.2 & 5.3 \\ 30.00 & 0.9 & 1.4 & 1.7 & 2.1 & 2.2 & 2.3 & 2.3 & 2.4 & 2.4\end{array}$

Case $8 \mathrm{~V}=5000 \mathrm{gal}, \mathrm{k}=0.6, \mathrm{~K}_{\mathrm{D}}=0.6, \mathrm{R}=1.053, \mathrm{a}=6.95 \mathrm{ft}$

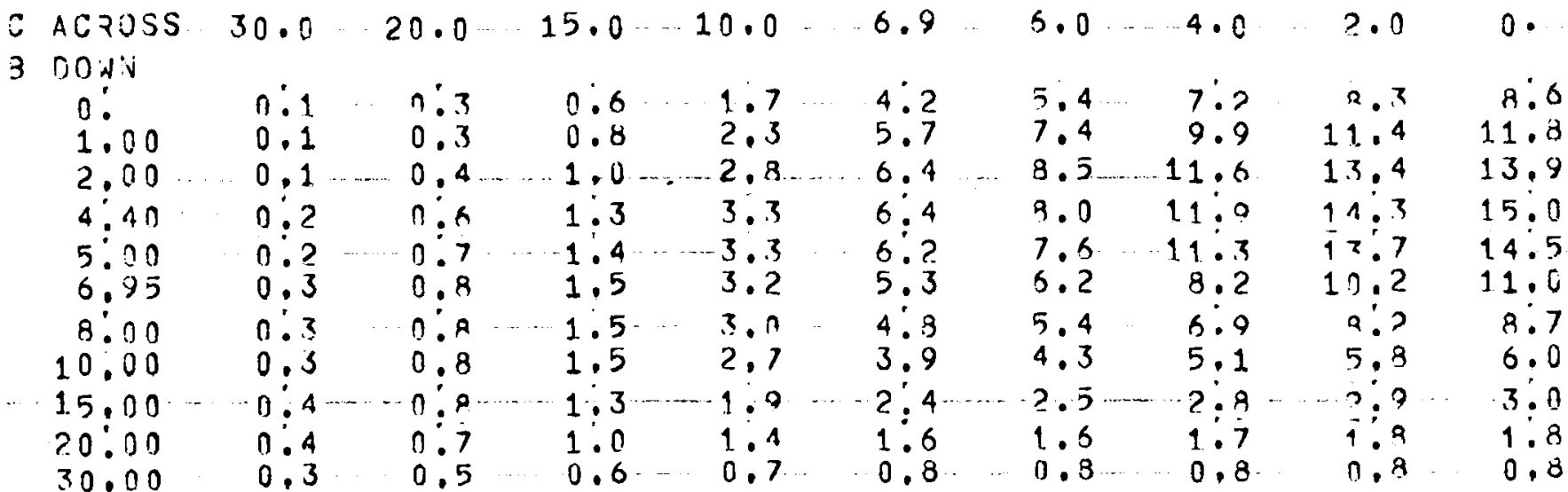

Case $9 \mathrm{~V}=10,000 \mathrm{gal}, \mathrm{k}=0.15, \mathrm{~K}_{\mathrm{D}}=0, \mathrm{R}=2.857, \mathrm{a}=12.22 \mathrm{ft}$

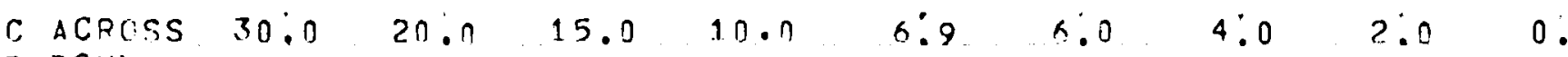
B DOWN

\begin{tabular}{|c|c|c|c|c|c|c|c|c|c|}
\hline 0.00 & $\begin{array}{l}0.2 \\
0.4\end{array}$ & $\begin{array}{l}n .6 \\
1.6\end{array}$ & $\begin{array}{l}1.5 \\
4.1\end{array}$ & $\begin{array}{r}5.4 \\
1.3 .5\end{array}$ & $\begin{array}{r}5: 9 \\
17: 3\end{array}$ & $\begin{array}{r}7 \% ? \\
18.1\end{array}$ & $\begin{array}{r}7: 7 \\
19.3\end{array}$ & $\begin{array}{r}7.9 \\
20.0\end{array}$ & $\begin{array}{r}8.0 \\
20.3\end{array}$ \\
\hline 2.00 & 0.7 & $? .5$ & 6.4 & 19.8 & $25: 8$ & $27^{\circ} 0$ & $29: 0$ & 30.1 & 30.4 \\
\hline 4.40 & 1.3 & 4.5 & 10.5 & 28.7 & 38.7 & 40.9 & 44.3 & 46.3 & 47.0 \\
\hline 5.30 & 1.5 & 4.9 & 11.1 & 29.6 & $40: 4$ & 42.9 & $46: 6$ & 48.3 & 49.6 \\
\hline 6.95 & 1.9 & 6.0 & 12.6 & 29.8 & 42.7 & 45.7 & 50.4 & 53.1 & 54.0 \\
\hline .00 & 2.1 & 6.4 & 12.9 & 28.4 & 41,9 & 45.1 & 50.2 & 53.2 & 54,1 \\
\hline .00 & 2.5 & 6.9 & 13.0 & 25.2 & 36.6 & 40.1 & 45.8 & 49.2 & 50.3 \\
\hline n & 3.0 & 7.1 & 11.3 & 17.6 & $22: 0$ & 23.4 & 25.8 & 27.1 & 28.0 \\
\hline 00 & $3: 1$ & 6.4 & 9.1 & $12 . x$ & $14: ?$ & 14.8 & 15.7 & $16 . x$ & 16.5 \\
\hline$n n$ & 2.8 & 4.6 & 5.6 & 6.6 & $7: 1$ & 7.3 & $7: 5$ & 7.6 & 7.7 \\
\hline
\end{tabular}


BNWL- 181

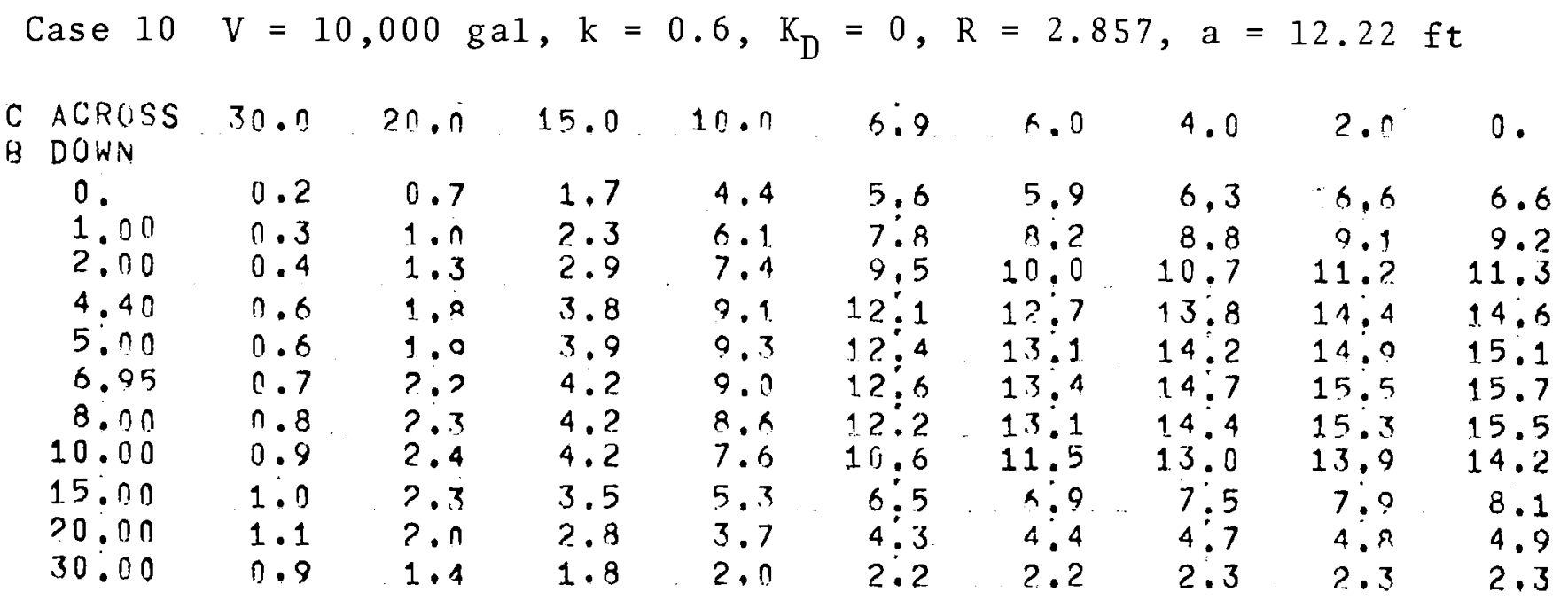

Case $11 \mathrm{~V}=10,000 \mathrm{gal}, \mathrm{k}=0.15, \mathrm{~K}_{\mathrm{D}}=0.6, \mathrm{R}=1.053, \mathrm{a}=8.76 \mathrm{ft}$

\begin{tabular}{|c|c|c|c|c|c|c|c|c|c|}
\hline $\begin{array}{l}\text { ACRCSS } \\
\text { DOWN }\end{array}$ & 30.0 & 20.0 & 15,0 & 10.0 & 6.9 & 6.0 & 4.0 & 2.0 & 0. \\
\hline $\begin{array}{l}0: \\
1.00 \\
2.00 \\
4.40 \\
5.00\end{array}$ & $\begin{array}{l}0.1 \\
0.3 \\
0.5 \\
1.0 \\
1.1\end{array}$ & $\begin{array}{l}0.4 \\
1.9 \\
1.8 \\
3.2 \\
3.5\end{array}$ & $\begin{array}{l}1.0 \\
2.7 \\
4.3 \\
7.3 \\
7.8\end{array}$ & $\begin{array}{l}4 . ? \\
10 . ? \\
15.1 \\
21.3 \\
21.8\end{array}$ & $\begin{array}{l}10.6 \\
25.8 \\
36.3 \\
45.7 \\
45.0\end{array}$ & $\begin{array}{l}11.9 \\
20 . ? \\
41.5 \\
53.8 \\
53.6\end{array}$ & $\begin{array}{l}13.8 \\
34.1 \\
49.1 \\
66.3 \\
67.1\end{array}$ & $\begin{array}{l}14.0 \\
36.8 \\
53.2 \\
73.5 \\
74.8\end{array}$ & $\begin{array}{l}15.2 \\
37.7 \\
54.6 \\
75.8 \\
77.3\end{array}$ \\
\hline $\begin{array}{r}6.95 \\
8.00 \\
10.00 \\
15.00 \\
20.00\end{array}$ & $\begin{array}{l}1.4 \\
1.5 \\
1.8 \\
2.2 \\
2.3\end{array}$ & $\begin{array}{l}4 \cdot 3 \\
4 \cdot 7 \\
5 \cdot \frac{1}{1} \\
5 \cdot 3 \\
4 \cdot 8\end{array}$ & $\begin{array}{l}9.0 \\
9.4 \\
9.6 \\
3.5 \\
6.8\end{array}$ & $\begin{array}{r}21.8 \\
21.0 \\
18.9 \\
1.3 .4 \\
9.3\end{array}$ & $\begin{array}{l}38: 5 \\
34: 7 \\
28: 1 \\
16: 9 \\
10: 8\end{array}$ & $\begin{array}{l}45: 5 \\
40: 1 \\
31: 4 \\
17: 9 \\
11: 3\end{array}$ & $\begin{array}{l}60: 7 \\
52: 3 \\
38: 2 \\
19: 9 \\
12: 0\end{array}$ & $\begin{array}{l}69: 9 \\
61: 9 \\
43: 5 \\
21: 3 \\
12.5\end{array}$ & $\begin{array}{l}72.9 \\
65.1 \\
45.5 \\
21.8 \\
12.7\end{array}$ \\
\hline 30.00 & 2.1 & 3.4 & 4.2 & $5 . ?$ & $5: 4$ & 5.5 & 5.7 & $5 . ?$ & 5.8 \\
\hline
\end{tabular}

Case $12 \mathrm{~V}=10,000 \mathrm{gal}, \mathrm{k}=0.6, \mathrm{~K}_{\mathrm{D}}=0.6, \mathrm{R}=1.053, \mathrm{a}=8.76 \mathrm{ft}$

\begin{tabular}{|c|c|c|c|c|c|c|c|c|c|}
\hline ACROSS & $s_{1} \cdot 3$ & 20.0 & 15.0 & $10 \cdot 0$ & 6.9 & o. ll & $4 \cdot 0$ & $? 0$ & 0. \\
\hline no & & & & & & & & & \\
\hline 0 & $0 . ?$ & 0.5 & 1.3 & $4 . ?$ & 8.1 & 9.1 & $10 \cdot 6$ & 11.5 & $11 . ?$ \\
\hline 1.00 & $0 .<$ & 0.9 & 1.8 & 2.4 & 11.1 & $12 . j$ & 14.6 & 25.8 & $16 \cdot 2$ \\
\hline 2,00 & 0.3 & $1 \cdot ?$ & $2 \cdot 2$ & 6.4 & 13.2 & 14.9 & 17.5 & 19.0 & 19.5 \\
\hline 4.40 & 0.5 & 1.4 & 3.0 & $1 . h$ & 14.5 & $\div 5.8$ & 20.4 & 2.2 .4 & 23.1 \\
\hline 5.00 & 0.5 . & 1.5 & 3.1 & 1.6 & 14.1 & 16.5 & 20.3 & 22.5 & 23.2 \\
\hline 6.95 & 0.6 & 1.7 & 3.4 & 7.5 & 12.0 & 15.9 & 17.9 & 20.4 & 21.2 \\
\hline 8.00 & 0.6 & $1, k$ & 3.4 & 0.9 & 10.8 & 12.3 & 15.5 & 18,1 & 18.9 \\
\hline 10.00 & 0.7 & 1.9 & 3.4 & 5.2 & 8.8 & 9.7 & 11.5 & 13.0 & 13.5 \\
\hline 15,00 & 0.3 & 1.? & 2.9 & 4.3 & 5.4 & 5.7 & 6.2 & 5.5 & 6.8 \\
\hline 20,00 & 0.9 & 1.7 & 2.3 & 3.1 & 3.5 & 3.6 & 3.9 & 4.0 & 4.0 \\
\hline $30: 00$ & $0 . E$ & $1: 2$ & 1.4 & 1.7 & 1.8 & 1.8 & 1.9 & 1.0 & 1.9 \\
\hline
\end{tabular}


Case $13 \mathrm{~V}=25,000 \mathrm{gal}, \mathrm{k}=0.15, \mathrm{~K}_{\mathrm{D}}=0, \mathrm{R}=2.857, \mathrm{a}=16.58 \mathrm{ft}$

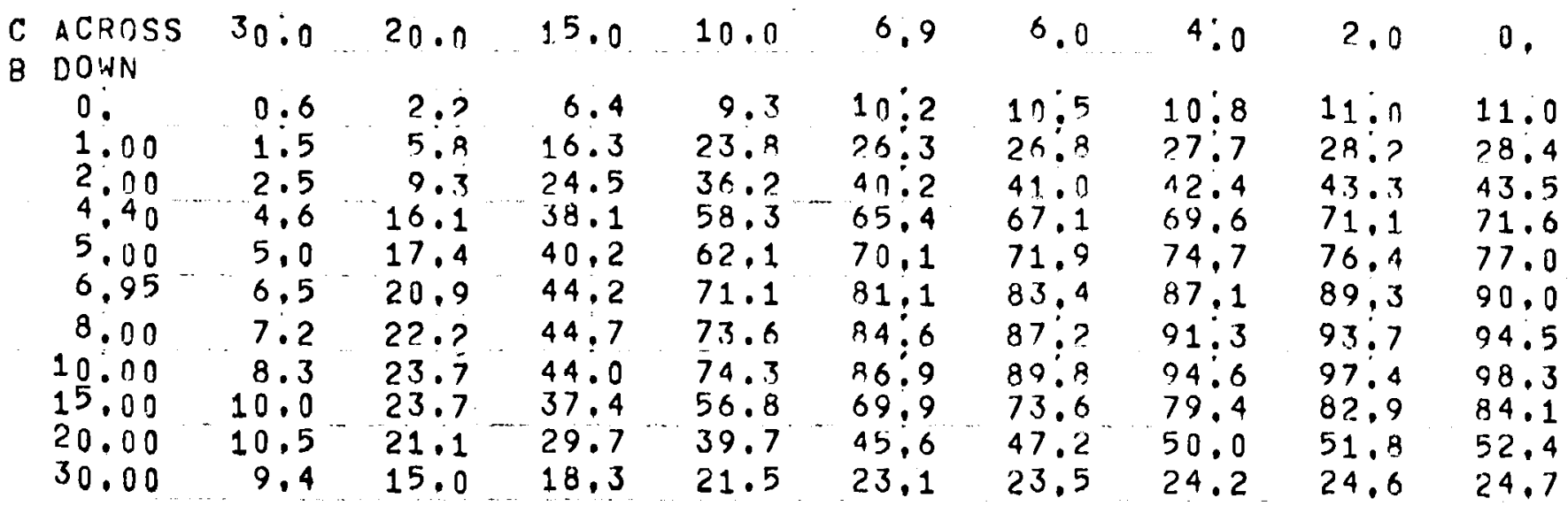

Case $14 \mathrm{~V}=25,000 \mathrm{gal}, \mathrm{k}=0.6, \mathrm{~K}_{\mathrm{D}}=0, \mathrm{R}=2.857, \mathrm{a}=16.58 \mathrm{ft}$

C ACROSS 30.0 20.0 15.0 $10.0 \quad 6: 9 \quad 6.0 \quad 4.0 \quad 2.0 \quad 0$, $B$ DOWN

\begin{tabular}{|c|c|c|c|c|c|c|c|c|c|}
\hline $0 !$ & 0.7 & 2.4 & 5.5 & 8.0 & 8,8 & 9.0 & 9.4 & 9.5 & 9.6 \\
\hline $\begin{array}{l}1: 00 \\
2.00\end{array}$ & $\begin{array}{l}1.0 \\
1.2\end{array}$ & $\begin{array}{l}3.4 \\
4.2\end{array}$ & $\begin{array}{l}7.7 \\
9.5\end{array}$ & $\begin{array}{l}11.1 \\
13.8\end{array}$ & $\begin{array}{l}12: 3 \\
15,3\end{array}$ & $\begin{array}{l}12.6 \\
15.7\end{array}$ & $\begin{array}{l}13^{\circ} .1 \\
16.3^{\prime}\end{array}$ & $\begin{array}{l}1.3 .3 \\
16.6\end{array}$ & $\begin{array}{l}13.4 \\
16.7\end{array}$ \\
\hline $\begin{array}{l}4: 40 \\
5: 90 \\
6.95\end{array}$ & $\begin{array}{l}1.8 \\
2.0 \\
2.3\end{array}$ & $\begin{array}{l}5.8 \\
6.1 \\
6.9\end{array}$ & $\begin{array}{l}12.4 \\
12.8 \\
13.5\end{array}$ & $\begin{array}{l}18.5 \\
19.3 \\
21.0\end{array}$ & $\begin{array}{l}20: 7 \\
21.7 \\
23.9\end{array}$ & $\begin{array}{l}21.2 \\
22.2 \\
24.5\end{array}$ & $\begin{array}{l}22.0 \\
23.1 \\
25.6\end{array}$ & $\begin{array}{l}2 ? .5 \\
23.6 \\
26.2\end{array}$ & $\begin{array}{l}22.7 \\
23.8 \\
26.4\end{array}$ \\
\hline 3.00 & $\begin{array}{l}2.5 \\
2.8\end{array}$ & $\begin{array}{l}7.2 \\
7.4\end{array}$ & $\begin{array}{l}13.5 \\
13.1\end{array}$ & $\begin{array}{l}21.4 \\
21 . ?\end{array}$ & $\begin{array}{l}24.5 \\
24.6\end{array}$ & $\begin{array}{l}25.2 \\
25.4\end{array}$ & $\begin{array}{l}26.3 \\
26.7\end{array}$ & $\begin{array}{l}27.0 \\
27.4\end{array}$ & $\begin{array}{l}27.2 \\
27.7\end{array}$ \\
\hline & $\begin{array}{l}3.2 \\
3.3 \\
2.9\end{array}$ & $\begin{array}{l}7: 5 \\
6.3 \\
4.5\end{array}$ & $\begin{array}{r}10.9 \\
8.7 \\
5.4\end{array}$ & $\begin{array}{r}16.1 \\
11.4 \\
6.3\end{array}$ & $\begin{array}{r}19: 5 \\
12: 9 \\
6: 7\end{array}$ & $\begin{array}{r}20: 5 \\
13: 3 \\
6: 8\end{array}$ & $\begin{array}{r:}22: 0 \\
14: 1 \\
7: 0\end{array}$ & $\begin{array}{r}22: 9 \\
14: 9 \\
7: 1\end{array}$ & $\begin{array}{r}23,2 \\
14.7 \\
7.1\end{array}$ \\
\hline
\end{tabular}

Case $15 \mathrm{~V}=25,000 \mathrm{gal}, \mathrm{k}=0.15, \mathrm{~K}_{\mathrm{D}}=0.6, \mathrm{R}=1.053, \mathrm{a}=11.89 \mathrm{ft}$

\begin{tabular}{|c|c|c|c|c|c|c|c|c|c|}
\hline $\begin{array}{l}\text { ACROSS } \\
\text { DOWN }\end{array}$ & 30.0 & $20 \cdot n$ & 15.0 & 10.0 & 6.9 & 6.0 & $4: 0$ & 2.0 & 0. \\
\hline $\begin{array}{l}0 . \\
1.00 \\
2.00 \\
4.40\end{array}$ & $\begin{array}{l}0.4 \\
1.1 \\
1.7 \\
3.3\end{array}$ & $\begin{array}{r}1.4 \\
3.8 \\
6.1 \\
10.9\end{array}$ & $\begin{array}{r}3.7 \\
9.8 \\
15.4 \\
25.3\end{array}$ & $\begin{array}{l}13.8 \\
34.4 \\
50.1 \\
71.5\end{array}$ & $\begin{array}{l}18.0 \\
45.1 \\
60.9 \\
99.4\end{array}$ & $\begin{array}{r}18.8 \\
47.4 \\
70.4 \\
105.5\end{array}$ & $\begin{array}{r}20.1 \\
50.8 \\
75.8 \\
115.1\end{array}$ & $\begin{array}{r}20.9 \\
52.7 \\
78.9 \\
120.7\end{array}$ & $\begin{array}{r}21.1 \\
53.4 \\
79.9 \\
122.5\end{array}$ \\
\hline $\begin{array}{l}5.00 \\
6.95 \\
8.00\end{array}$ & $\begin{array}{l}3.6 \\
4.6 \\
5.1\end{array}$ & $\begin{array}{l}11: 9 \\
14: 5 \\
15: 6\end{array}$ & $\begin{array}{l}26.9 \\
30.6 \\
31.5\end{array}$ & $\begin{array}{l}73.5 \\
72.5 \\
69.2\end{array}$ & $\begin{array}{l}103: 6 \\
108: 2 \\
105: 1\end{array}$ & $\begin{array}{l}110: 3 \\
116: 4 \\
113: 9\end{array}$ & $\begin{array}{l}120: 9 \\
129: 3 \\
127: 9\end{array}$ & $\begin{array}{l}127: 0 \\
136: 9 \\
136.2\end{array}$ & $\begin{array}{l}129.0 \\
139.4 \\
138.9\end{array}$ \\
\hline $\begin{array}{l}10.00 \\
15: 00\end{array}$ & $\begin{array}{l}6.0 \\
7.3\end{array}$ & $\begin{array}{l}16.9 \\
17.3\end{array}$ & $\begin{array}{l}31: 7 \\
27: 7\end{array}$ & $\begin{array}{l}61.6 \\
43.1\end{array}$ & $\begin{array}{r}89: 5 \\
53: 9\end{array}$ & $\begin{array}{l}90.0 \\
57: 1\end{array}$ & $\begin{array}{r}114.7 \\
63.1\end{array}$ & $\begin{array}{r}123.9 \\
67.2\end{array}$ & $\begin{array}{r}127.0 \\
58.6\end{array}$ \\
\hline $\begin{array}{l}20: 00 \\
30: 00\end{array}$ & $\begin{array}{l}7: 7 \\
6.9\end{array}$ & $\begin{array}{l}15.6 \\
11.9\end{array}$ & $\begin{array}{l}22.1 \\
13.7\end{array}$ & $\begin{array}{l}30.1 \\
16.2\end{array}$ & $\begin{array}{l}34: 8 \\
17: 4\end{array}$ & $\begin{array}{l}36: 1 \\
17.7\end{array}$ & $\begin{array}{l}38.4 \\
18.3\end{array}$ & $\begin{array}{l}39.9 \\
18.6\end{array}$ & $\begin{array}{l}40.4 \\
18.7\end{array}$ \\
\hline
\end{tabular}




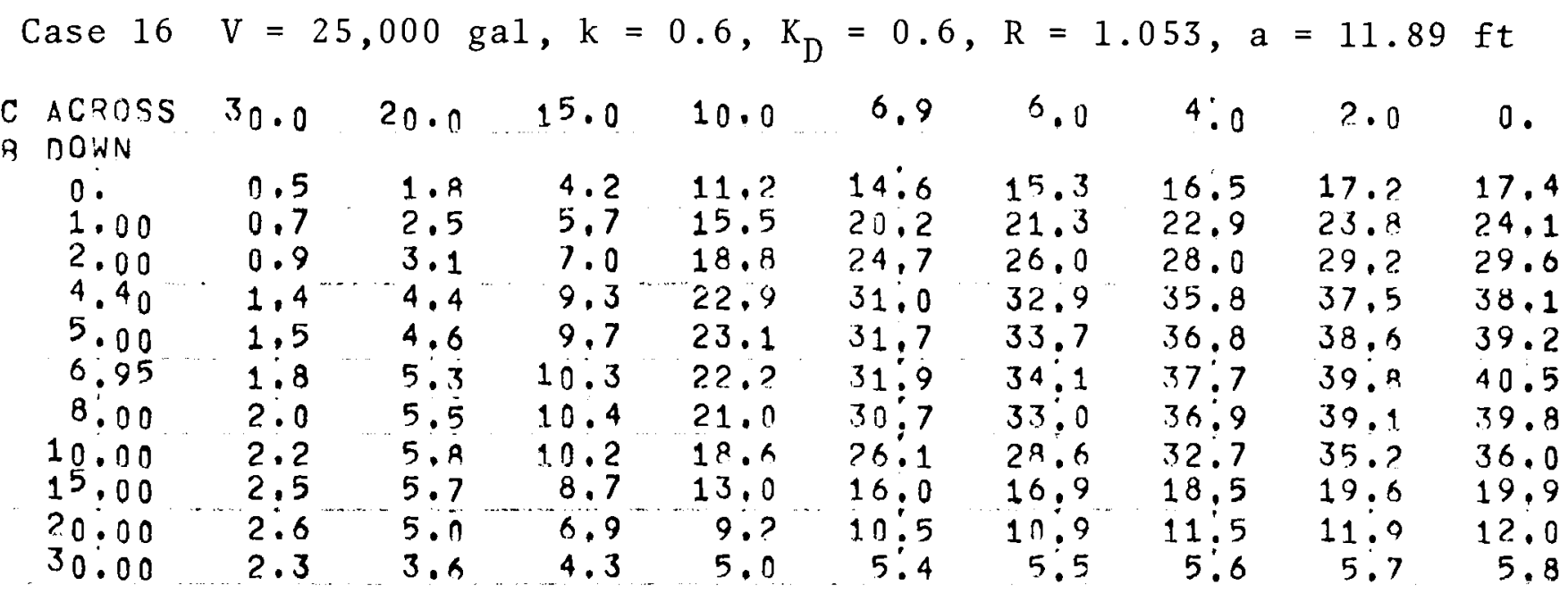

Case $17 \mathrm{~V}=50,000 \mathrm{gal}, \mathrm{k}=0.15, \mathrm{~K}_{\mathrm{D}}=0, \mathrm{R}=2.857, \mathrm{a}=20.89 \mathrm{ft}$

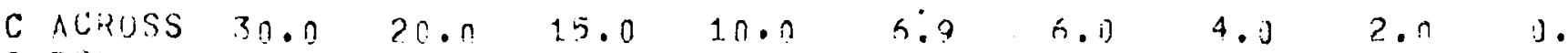

8 DUWN

0 .

1.0 0

$1.5 \quad 7.1 \quad 10.8$

12.7

$13.4 \quad 1.3 .6$

13.3

14.0

14.0

2.00

4.0

1.2. 3

27.3

32.9

34.7

35.2

35.3

36.3

36.4

$4.4 n$

6.5

45.1

70.9

.

$53: 9$

55.7

56.3

5.5 .5

$5.00 \quad 13.2$

$48.6 \quad 70.3$

92.3

21.4 n2.?

24.7

$96 . ?$

36.4

6.95

16.9

b6.?

90.2

$111 . ?$

99.0100 .4

102.3

104.1

1i] 4.6

8.011

18.6

58.7

95.1

112.4

119.2121 .1

124.1

125.9

120.5

$10.0 n \quad 21.3$

$15.2 n$

25.4

$64.1 \quad 100.6$

12.7 .6

$127.4 \quad 129.5$

132.

1.54 .9

1.55 .5

$59.6 \quad 0 ? .2$

126.1

$138: ? \quad 140.7$

144.6

$147.0 \quad 147.8$

$20.00 \quad 26.3$

$52.4 \quad 72.6$

45.9

139.5

$14 ? .8$

$1+8.9$

151.

152.1

30.90

23.3

36.8

$5 ? .3$

$109: 2$
55.0

112.6

123.7

$122.3 \quad 223.5$

$59.5 \quad 59.9$

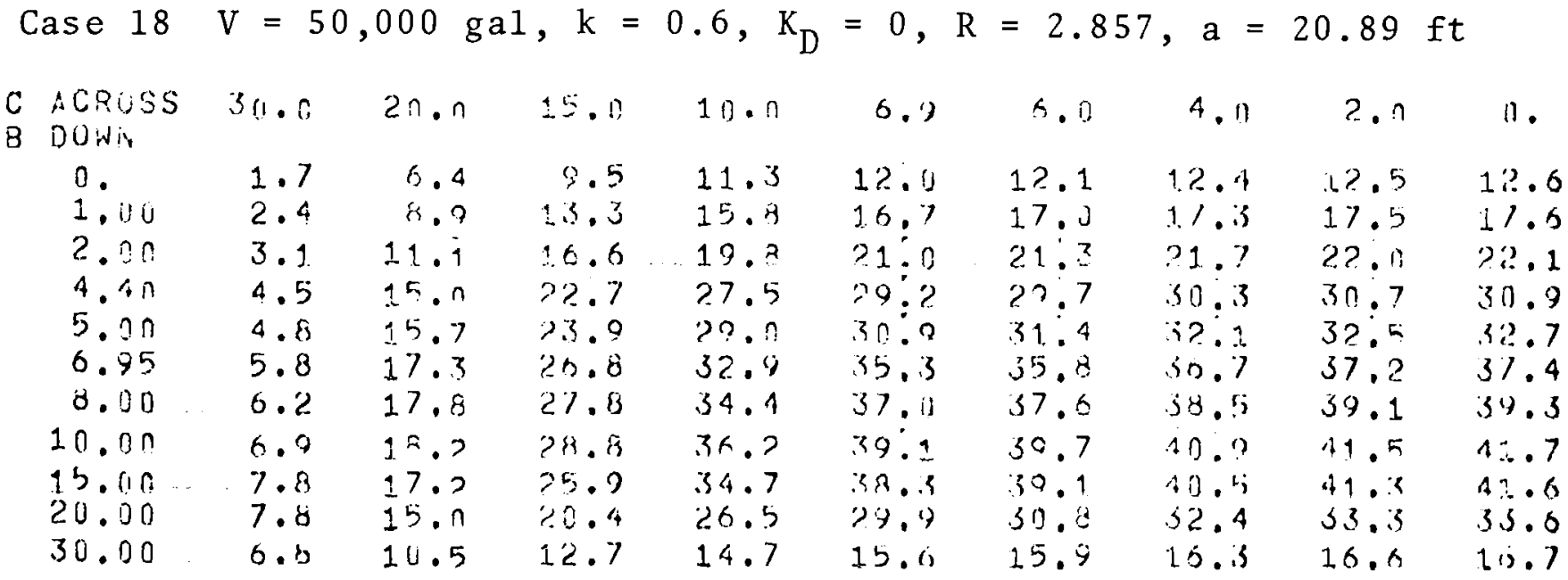


BNWL-181

Case $19 \mathrm{~V}=50,000 \mathrm{gal}, \mathrm{k}=0.15, \mathrm{~K}_{\mathrm{D}}=0.6, \mathrm{R}=1.053, \mathrm{a}=14.98 \mathrm{ft}$

\begin{tabular}{|c|c|c|c|c|c|c|c|c|c|}
\hline $\begin{array}{l}\text { ACRUSS } \\
\text { DUWN }\end{array}$ & 30.0 & 20.0 & 15.0 & 10.0 & 6.9 & 6.0. & 4.0 & 2.0 & 0 . \\
\hline 0.00 & $\begin{array}{l}1.0 \\
2.7\end{array}$ & $\begin{array}{r}3.8 \\
10.1\end{array}$ & $\begin{array}{l}11.4 \\
29.2\end{array}$ & $\begin{array}{l}21.6 \\
54.0\end{array}$ & $\begin{array}{l}24.5 \\
52.5\end{array}$ & $\begin{array}{l}25.2 \\
64.2\end{array}$ & $\begin{array}{l}26.2 \\
66.9\end{array}$ & $\begin{array}{l}26.7 \\
68.4\end{array}$ & $\begin{array}{l}26.9 \\
68.9\end{array}$ \\
\hline 2.00 & 4.4 & 16.1 & 44.0 & 8.2 .7 & $94: 9$ & 97.5 & $1 \cap 1.8$ & $104: 3$ & 105.1 \\
\hline $\begin{array}{l}4.4 \pi \\
5.00\end{array}$ & $\begin{array}{l}3.2 \\
9.0\end{array}$ & $\begin{array}{l}28.4 \\
30.7\end{array}$ & $\begin{array}{l}67.8 \\
71.4\end{array}$ & $\begin{array}{l}129.4 \\
136.9\end{array}$ & $\begin{array}{l}151.2 \\
160.8\end{array}$ & $\begin{array}{l}156.1 \\
1 \in 6.2\end{array}$ & $\begin{array}{l}163.7 \\
174.7\end{array}$ & $\begin{array}{l}168 . ? \\
179.8\end{array}$ & $\begin{array}{l}16.9 .7 \\
181.4\end{array}$ \\
\hline $\begin{array}{l}6.95 \\
8.00\end{array}$ & $\begin{array}{l}11.6 \\
12.9\end{array}$ & $\begin{array}{l}37.2 \\
39.6\end{array}$ & $\begin{array}{l}7 R .7 \\
80.1\end{array}$ & $\begin{array}{l}152.7 \\
154.3\end{array}$ & $\begin{array}{l}191.8 \\
186.8\end{array}$ & $\begin{array}{l}189.6 \\
194.3\end{array}$ & $\begin{array}{l}199.5 \\
206.2\end{array}$ & $\begin{array}{l}205 . ? \\
213.3\end{array}$ & $\begin{array}{l}208.0 \\
215.6\end{array}$ \\
\hline 10.00 & 15.0 & 47.6 & 79.5 & $14 \pi . ?$ & $105^{\circ}: 0$ & 193.5 & $207: 2$ & $215^{\circ} \cdot 3$ & 21.8 .0 \\
\hline $\begin{array}{l}15.00 \\
2.0 .00\end{array}$ & $\begin{array}{l}18.2 \\
19.0\end{array}$ & $\begin{array}{l}43^{2} \cdot 1 \\
38.5\end{array}$ & $\begin{array}{l}58.2 \\
34.2\end{array}$ & $\begin{array}{r}104.5 \\
73.0\end{array}$ & $\begin{array}{r}129.4 \\
84.0\end{array}$ & $\begin{array}{r}13.5 .7 \\
87.1\end{array}$ & $\begin{array}{r}150.1 \\
92.4\end{array}$ & $\begin{array}{r}159.2 \\
95.8\end{array}$ & $\begin{array}{r}142.4 \\
97.0\end{array}$ \\
\hline 30.00 & 17.1 & 27.3 & 33.5 & 39.4 & 42.3 & 43.1 & 44.4 & $45 . ?$ & 45.4 \\
\hline
\end{tabular}

Case $20 \mathrm{~V}=50,000 \mathrm{gal}, \mathrm{k}=0.6, \mathrm{~K}_{\mathrm{D}}=0.6, \mathrm{R}=1.053, \mathrm{a}=14.98 \mathrm{ft}$

\begin{tabular}{|c|c|c|c|c|c|c|c|c|c|}
\hline $\begin{array}{l}\text { ACROSS } \\
\text { DOWN }\end{array}$ & $3_{0} \cdot 0$ & $20 \cdot 0$ & $1^{5} \cdot 0$ & $10 \cdot n$ & $6: 9$ & 6.0 & $4: 0$ & 2.0 & 0. \\
\hline $\begin{array}{l}0 . \\
1.00 \\
2.00\end{array}$ & $\begin{array}{l}1.3 \\
1.8 \\
2.3\end{array}$ & $\begin{array}{l}4.4 \\
6.1 \\
7.6\end{array}$ & $\begin{array}{l}10.5 \\
14.5 \\
17.8\end{array}$ & $\begin{array}{l}18.2 \\
25.3 \\
31.2\end{array}$ & $\begin{array}{l}20.8 \\
29.0 \\
35.9\end{array}$ & $\begin{array}{l}21.4 \\
29.8 \\
36.9\end{array}$ & $\begin{array}{l}22.4 \\
31.1 \\
38.6\end{array}$ & $\begin{array}{l}22.9 \\
31.9 \\
39.5\end{array}$ & $\begin{array}{l}23.1 \\
32.2 \\
39.9\end{array}$ \\
\hline $\begin{array}{l}4.40 \\
5.00 \\
6.95 \\
8.00\end{array}$ & $\begin{array}{l}3.3 \\
3.6 \\
4.3 \\
4.7\end{array}$ & $\begin{array}{l}10.8 \\
11.2 \\
12.7 \\
13.2\end{array}$ & $\begin{array}{l}22.8 \\
23.6 \\
24.8 \\
24.8\end{array}$ & $\begin{array}{l}40.9 \\
42.4 \\
45.0 \\
45.0\end{array}$ & $\begin{array}{l}47: 6 \\
49: 5 \\
53: 4 \\
54: 0\end{array}$ & $\begin{array}{l}49: 1 \\
51: 1 \\
55: 3 \\
56.1\end{array}$ & $\begin{array}{l}51: 5 \\
53: 8 \\
58.4 \\
59.4\end{array}$ & $\begin{array}{l}53.7 \\
55.3 \\
60.2 \\
61.3\end{array}$ & $\begin{array}{l}53.4 \\
55.8 \\
60.8 \\
62.0\end{array}$ \\
\hline $\begin{array}{l}10: 00 \\
15: 00\end{array}$ & $\begin{array}{l}5: 2 \\
5.9\end{array}$ & $\begin{array}{l}13.7 \\
13.3\end{array}$ & $\begin{array}{l}24.2 \\
20.4\end{array}$ & $\begin{array}{l}42.7 \\
30.2\end{array}$ & $\begin{array}{l}5 ?: 5 \\
36: 7\end{array}$ & $\begin{array}{l}54: 8 \\
38: 7\end{array}$ & $\begin{array}{l}58: 5 \\
42: 2\end{array}$ & $\begin{array}{l}60.7 \\
44.5\end{array}$ & $\begin{array}{l}61.4 \\
45.4\end{array}$ \\
\hline $\begin{array}{l}20: 00 \\
30.00\end{array}$ & $\begin{array}{l}6,1 \\
5,3\end{array}$ & $\begin{array}{r}11.7 \\
8.3\end{array}$ & $\begin{array}{l}16.1 \\
10.0\end{array}$ & $\begin{array}{l}21.3 \\
11.7\end{array}$ & $\begin{array}{l}24.2 \\
12.5\end{array}$ & $\begin{array}{l}25.0 \\
12.7\end{array}$ & $\begin{array}{l}26.5 \\
13.1\end{array}$ & $\begin{array}{l}27 \cdot 4 \\
13,3\end{array}$ & $\begin{array}{l}27.7 \\
13.4\end{array}$ \\
\hline
\end{tabular}

Case $21 \mathrm{~V}=100,000 \mathrm{gal}, \mathrm{k}=0.15, \mathrm{~K}_{\mathrm{D}}=0, \mathrm{R}=2.857, \mathrm{a}=26.32 \mathrm{ft}$

\begin{tabular}{|c|c|c|c|c|c|c|c|c|c|}
\hline $\begin{array}{l}\text { ACROSS } \\
\text { DOWN }\end{array}$ & 0. & $2: 0$ & 4.0 & 6.0 & 6.9 & 10.0 & 15.0 & 20.0 & 30.0 \\
\hline $\begin{array}{l}30.00 \\
20.00\end{array}$ & $\begin{array}{l}143 . ? \\
235.4\end{array}$ & $\begin{array}{l}143.1 \\
234.4\end{array}$ & $\begin{array}{l}140,9 \\
231,2\end{array}$ & $\begin{array}{l}137.3 \\
223.9\end{array}$ & $\begin{array}{l}135.1 \\
222.6\end{array}$ & $\begin{array}{l}125.6 \\
208.8\end{array}$ & $\begin{array}{l}109.2 \\
174.8\end{array}$ & $\begin{array}{r}90.5 \\
129.9\end{array}$ & $\begin{array}{l}58.1 \\
66.6\end{array}$ \\
\hline 15.00 & 241.8 & 240.9 & 238.3 & 235.9 & 231.1 & 219.5 & 190.6 & 148.1 & 65.4 \\
\hline $\begin{array}{r}10.00 \\
8.00\end{array}$ & $\begin{array}{l}211.7 \\
188.2\end{array}$ & $\begin{array}{l}211.1 \\
187.7\end{array}$ & $\begin{array}{l}209.1 \\
186,0\end{array}$ & $\begin{array}{l}203,8 \\
183.5\end{array}$ & $\begin{array}{l}203.8 \\
181.6\end{array}$ & $\begin{array}{l}195.1 \\
174.3\end{array}$ & $\begin{array}{l}173.3 \\
155.9\end{array}$ & $\begin{array}{l}140.2 \\
127.8\end{array}$ & $\begin{array}{l}56,4 \\
49,8\end{array}$ \\
\hline 0,95 & 173.0 & 172.5 & 171.1 & 168,6 & 167.1 & 160.7 & 144.2 & 118.9 & 45.5 \\
\hline 5.00 & 139.3 & 139.0 & 137.9 & 156.0 & 134.9 & 130.0 & 117.4 & 97.8 & 36.0 \\
\hline 4.40 & 127.5 & 127.2 & 126.2 & 124,5 & 123.5 & 119.1 & 107.8 & 90,1 & 32.7 \\
\hline $2: 00$ & -72.7 & $72: 6$ & 72.0 & 71,2 & 70.6 & 69.3 & 62.3 & 52.7 & 17.7 \\
\hline $\begin{array}{l}1: 00 \\
0: 0\end{array}$ & $\begin{array}{l}46.3 \\
17.7\end{array}$ & $\begin{array}{l}46: ? \\
17: 6\end{array}$ & $\begin{array}{r}45.9 \\
17.5\end{array}$ & $\begin{array}{l}45.3 \\
17 . ?\end{array}$ & $\begin{array}{l}45: 0 \\
17: 1\end{array}$ & $\begin{array}{l}43.6 \\
15.6\end{array}$ & $\begin{array}{l}39.8 \\
15: 1\end{array}$ & $\begin{array}{l}3.3 .8 \\
12.9\end{array}$ & $\begin{array}{r}10.8 \\
3.7\end{array}$ \\
\hline
\end{tabular}


Case $22 \mathrm{~V}=100,000 \mathrm{ga}, \mathrm{k}=0.6, \mathrm{~K}_{\mathrm{D}}=0, \mathrm{R}=2.857, \mathrm{a}=26.32 \mathrm{ft}$

\begin{tabular}{|c|c|c|c|c|c|c|c|c|c|}
\hline $\begin{array}{l}\text { ACRDSS } \\
\text { DOWN }\end{array}$ & 0. & $2 \cdot 0$ & 4.0 & 6.0 & 6.9 & $10 \cdot 0$ & $15 \cdot 0$ & $20 \cdot 0$ & 30.0 \\
\hline $30: 00$ & 38.9 & 38.7 & 38,1 & 31.2 & 36.6 & 34.4 & 29.9 & 25,0 & 16.4 \\
\hline $\begin{array}{l}20: 00 \\
15.00\end{array}$ & $\begin{array}{l}63.3 \\
66.0\end{array}$ & $\begin{array}{l}63: 0 \\
65: 8\end{array}$ & $\begin{array}{l}62.2 \\
65.1\end{array}$ & $\begin{array}{l}60.8 \\
63.9\end{array}$ & $\begin{array}{l}59: 9 \\
63.2\end{array}$ & $\begin{array}{l}5.5 .3 \\
60.1\end{array}$ & $\begin{array}{l}47.5 \\
52.4\end{array}$ & $\begin{array}{l}35: 9 \\
41.1\end{array}$ & $\begin{array}{l}19: 1 \\
19.1\end{array}$ \\
\hline $\begin{array}{r}10.00 \\
8.00\end{array}$ & $\begin{array}{l}60.0 \\
54.9\end{array}$ & $\begin{array}{l}59.8 \\
54.8\end{array}$ & $\begin{array}{l}59.3 \\
54.3\end{array}$ & $\begin{array}{l}59.4 \\
53.5\end{array}$ & $\begin{array}{l}57.8 \\
53.0\end{array}$ & $\begin{array}{l}55.4 \\
50.9\end{array}$ & $\begin{array}{l}49.3 \\
45,6\end{array}$ & $\begin{array}{l}4 \pi, 2 \\
37,5\end{array}$ & $\begin{array}{l}17.2 \\
15.7\end{array}$ \\
\hline $\begin{array}{l}6,95 \\
5,00 \\
4,40 \\
2,00 \\
1.00 \\
0 .\end{array}$ & $\begin{array}{l}51.5 \\
44.0 \\
41.5 \\
28.9 \\
22.8 \\
16.5\end{array}$ & $\begin{array}{l}51.4 \\
43.9 \\
41.2 \\
28.8 \\
22.8 \\
16.2\end{array}$ & $\begin{array}{l}51.0 \\
43.0 \\
40.9 \\
28.0 \\
22.6 \\
16.1\end{array}$ & $\begin{array}{l}50.2 \\
42.9 \\
40.3 \\
28.2 \\
22.5 \\
12.9\end{array}$ & $\begin{array}{l}49.8 \\
42.6 \\
40.0 \\
28.0 \\
22.2 \\
15.8\end{array}$ & $\begin{array}{l}47.9 \\
41.0 \\
38.5 \\
27.1 \\
21.4 \\
15.3\end{array}$ & $\begin{array}{l}43.0 \\
37.0 \\
34.9 \\
24.6 \\
19.5 \\
13.9\end{array}$ & $\begin{array}{l}35,6 \\
30,9 \\
29,2 \\
20,8 \\
16,5 \\
11,8\end{array}$ & $\begin{array}{r}14.7 \\
12.5 \\
11.7 \\
8.0 \\
6.3 \\
4.4\end{array}$ \\
\hline
\end{tabular}

Case $23 \mathrm{~V}=100,000 \mathrm{gal}, \mathrm{k}=0.15, \mathrm{~K}_{\mathrm{D}}=0.6, \mathrm{R}=1.053, \mathrm{a}=18.87 \mathrm{ft}$

\begin{tabular}{|c|c|c|c|c|c|c|c|c|c|}
\hline ACROSS & 0. & 2.0 & 4.0 & 0.0 & 6.9 & 10.0 & .15 .0 & $20 \cdot 0$ & 30.0 \\
\hline \multicolumn{10}{|l|}{ DOAN } \\
\hline $30: 00$ & 110.3 & 109.7 & 107.9 & 104.9 & 103.1 & 96.1 & $\$ 2.1$ & 67.1 & 42,5 \\
\hline 20.00 & 231.1 & 228.4 & 220.7 & 208,8 & 201.9 & 176.7 & 132.9 & 95.3 & 17.6 \\
\hline 15,110 & $325: 0$ & $32 ?: 1$ & 313,2 & 299.3 & 299.1 & 250.0 & 168,3 & $10 ? .9$ & 45.7 \\
\hline $10: 00$ & 337.6 & 335.3 & 328,4 & 316.7 & 309.5 & 279.3 & 198,4 & 100.4 & 38.1 \\
\hline $8: 00$ & 315,3 & 313,3 & 307.4 & 297.5 & $201: 3$ & 264.5 & 194.6 & 103.5 & 33.0 \\
\hline $\begin{array}{l}6.95 \\
5.00\end{array}$ & $\begin{array}{l}296.7 \\
248.5\end{array}$ & $\begin{array}{l}294.9 \\
247.1\end{array}$ & $\begin{array}{l}289.6 \\
243.0\end{array}$ & $\begin{array}{r}280.7 \\
2.36 .1\end{array}$ & $\begin{array}{l}275.1 \\
231.8\end{array}$ & $\begin{array}{l}250.9 \\
213.0\end{array}$ & $\begin{array}{l}187.1 \\
152.3\end{array}$ & $\begin{array}{l}9 n, 1 \\
83,2\end{array}$ & $\begin{array}{l}29.9 \\
23.2\end{array}$ \\
\hline $\begin{array}{l}4.40 \\
2.00\end{array}$ & $\begin{array}{l}229.9 \\
1.36 .0\end{array}$ & $\begin{array}{r}228.7 \\
136.0\end{array}$ & $\begin{array}{l}225.0 \\
134.0\end{array}$ & $\begin{array}{l}219.8 \\
150,7\end{array}$ & $\begin{array}{l}214.9 \\
128.6\end{array}$ & $\begin{array}{r}19 \% .9 \\
119.4\end{array}$ & $\begin{array}{r}151.7 \\
93.7\end{array}$ & $\begin{array}{l}77.1 \\
45.5\end{array}$ & $\begin{array}{l}20.9 \\
11.1\end{array}$ \\
\hline $\begin{array}{l}1.00 \\
0.1\end{array}$ & $\begin{array}{r}88.3 \\
34.1\end{array}$ & $\begin{array}{l}87,9 \\
33,9\end{array}$ & $\begin{array}{l}86.7 \\
33.4\end{array}$ & $\begin{array}{l}04.6 \\
5 ? .6\end{array}$ & $\begin{array}{l}83.3 \\
32.1\end{array}$ & $\begin{array}{l}77.6 \\
29.9\end{array}$ & $\begin{array}{l}61.4 \\
23.7\end{array}$ & $\begin{array}{l}28,8 \\
10,4\end{array}$ & $\begin{array}{l}6.7 \\
2.3\end{array}$ \\
\hline
\end{tabular}

Case $24 \mathrm{~V}=100,000 \mathrm{gal}, \mathrm{k}=0.6, \mathrm{~K}_{\mathrm{D}}=0.6, \mathrm{R}=1.053, \mathrm{a}=18.87 \mathrm{ft}$

\begin{tabular}{|c|c|c|c|c|c|c|c|c|c|}
\hline $\begin{array}{l}\text { ACROSS } \\
\text { DONN }\end{array}$ & 0. & $2 \cdot 0$ & $4 \cdot 0$ & 0.0 & 6.9 & $10 \cdot 1]$ & 15.0 & $20 \cdot 0$ & 30.0 \\
\hline $30: 00$ & 31.2 & 31.0 & 30,5 & 29.7 & 29.2 & 27.4 & 23.6 & 19.6 & 12.7 \\
\hline 20.00 & 63.1 & 63.0 & 61.0 & $b / .9$ & 56.1 & 49.5 & 37.9 & 27.8 & 14.6 \\
\hline 15.00 & 89.1 & 88.3 & 96.0 & 82.1 & $79: 7$ & 59.4 & $43: 0$ & 39.9 & 14.3 \\
\hline $\begin{array}{r}10.00 \\
8.00\end{array}$ & $\begin{array}{l}95 . ? \\
91.2\end{array}$ & $\begin{array}{l}94.5 \\
90.6\end{array}$ & $\begin{array}{l}92.6 \\
88.9\end{array}$ & $\begin{array}{l}85.4 \\
86.1\end{array}$ & $\begin{array}{l}97.4 \\
84.3\end{array}$ & $\begin{array}{l}78.9 \\
76.8\end{array}$ & $\begin{array}{l}57.3 \\
57.3\end{array}$ & $\begin{array}{l}37.3 \\
32.3\end{array}$ & $\begin{array}{l}12.5 \\
11.3\end{array}$ \\
\hline & $\begin{array}{l}87.4 \\
77.3\end{array}$ & $\begin{array}{l}86.9 \\
76.9\end{array}$ & $\begin{array}{l}85.4 \\
75.6\end{array}$ & $\begin{array}{l}82.7 \\
13.5\end{array}$ & $\begin{array}{l}81: 1 \\
72.1\end{array}$ & $\begin{array}{l}74.1 \\
66.3\end{array}$ & $\begin{array}{l}5.50 \\
51.0\end{array}$ & $\begin{array}{l}34 . ? \\
28.0\end{array}$ & $\begin{array}{r}10.5 \\
8.8\end{array}$ \\
\hline $\begin{array}{l}4.40 \\
2.00\end{array}$ & $\begin{array}{l}73: 3 \\
53: 0\end{array}$ & $\begin{array}{l}72.9 \\
52.7\end{array}$ & $\begin{array}{l}71.7 \\
51.9\end{array}$ & $\begin{array}{l}69.7 \\
50.6\end{array}$ & $\begin{array}{l}68.5 \\
49.7\end{array}$ & $\begin{array}{l}63 \cdot 1 \\
46.1\end{array}$ & $\begin{array}{l}48.7 \\
36.2\end{array}$ & $\begin{array}{l}24.7 \\
19.4\end{array}$ & $\begin{array}{l}8.2 \\
5.5\end{array}$ \\
\hline $\begin{array}{l}1.00 \\
0 .\end{array}$ & $\begin{array}{l}42.3 \\
30.3\end{array}$ & $\begin{array}{l}42 \cdot 1 \\
30 \cdot 1\end{array}$ & $\begin{array}{r}41.5 \\
29.7\end{array}$ & $\begin{array}{l}40.4 \\
28,9\end{array}$ & $\begin{array}{l}39.8 \\
28.4\end{array}$ & $\begin{array}{l}36.9 \\
26.4\end{array}$ & $\begin{array}{l}29.1 \\
20.8\end{array}$ & $\begin{array}{l}15.5 \\
11.1\end{array}$ & $\begin{array}{l}4.3 \\
3.0\end{array}$ \\
\hline
\end{tabular}


Case $25 \mathrm{~V}=100 \mathrm{gal}, \mathrm{k}=0.15, \mathrm{~K}_{\mathrm{D}}=500, \mathrm{R}=0.002, \mathrm{a}=0.23 \mathrm{ft}$

\begin{tabular}{|c|c|c|c|c|c|c|c|c|c|}
\hline $\begin{array}{l}\text { ACROSS } \\
\text { DOWN }\end{array}$ & $3 n \cdot 0$ & $20 . n$ & 15.0 & $10 \cdot 1$ & $6: 9$ & $6: 0$ & 4.0 & 2.0 & 0. \\
\hline 0 & $n .0$ & $0 . n$ & 0.0 & $n \cdot n$ & $n: 0$ & $0: 0$ & 0.1 & $0 . x$ & 40.0 \\
\hline $1 . n$ & C. 0 & $n . n$ & 0.0 & $n . n$ & $10: 0$ & 0.1 & 0.2 & 0 & 4.6 \\
\hline 2.50 & $n \cdot 0$ & $0 . n$ & 0.0 & $n \cdot n$ & $0: 1$ & 0.1 & 0.2 & 0.7 & 1.5 \\
\hline $4.4 n$ & 0.0 & $0 . n$ & 0.0 & $0 . n$ & $n: 1$ & 0.1 & 0.2 & $n .3$ & 0.4 \\
\hline 5.00 & 0.0 & 0.0 & 0.0 & 0.0 & $0: 1$ & 0.1 & 0.2 & 0.3 & \\
\hline 6.95 & 0.0 & $0 . n$ & 0.0 & n. & $n: 1$ & $0: 1$ & 0.1 & $n . ?$ & 0.2 \\
\hline 8.00 & $n .0$ & 0.0 & 0.0 & n. & $0: 1$ & $0: 1$ & 0.1 & $0: 1$ & 0.1 \\
\hline 10.00 & 0.0 & 0.0 & 0.0 & 0.1 & 0 & 0.1 & 0.1 & 0.1 & 0.1 \\
\hline 15.00 & 0.0 & 0.0. & 0.0 & $0 \cdot 0$ & 0.0 & 0.0 & 0.0 & 0 & 0.0 \\
\hline 20.00 & 0.0 & 0.0 & 0.0 & 0.0 & 0.0 & 0.0 & 0.0 & 0.0 & 0.0 \\
\hline 30.00 & 0.0 & 0.0 & 0.0 & 0.0 & 0,0 & 0.0 & 0.0 & 0,0 & \\
\hline
\end{tabular}

Case $26 \mathrm{~V}=100 \mathrm{gal}, \mathrm{k}=0.6, \mathrm{~K}_{\mathrm{D}}=500, \mathrm{R}=0.002, \mathrm{a}=0.23 \mathrm{ft}$

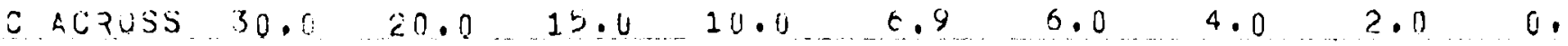

3 DONIV

$\begin{array}{cccccccccc}0: 0 & 0.0 & 0.0 & 0.0 & 0.0 & 0.0 & 0.1 & 0.2 & 0.6 & 11.0 \\ 1.00 & 0.0 & 0.0 & 0.0 & 0.0 & 0.1 & 0.1 & 0.2 & 0.5 & 1.0 \\ 2.00 & 0.0 & 0.0 & 0.0 & 0.0 & 0.1 & 0.1 & 0.2 & 0.4 & 0.1 \\ 4.40 & 0.0 & 0.0 & 0.0 & 0.0 & 0.1 & 0.1 & 0.1 & 0.2 & 0.2 \\ 5.10 & 0.0 & 0.0 & 0.0 & 0.0 & 0.1 & 0.1 & 0.1 & 0.2 & 0.2 \\ 6.95 & 0.0 & 0.0 & 0.0 & 0.0 & 0.1 & 0.1 & 0.1 & 0.1 & 0.1 \\ 8.00 & 0.0 & 0.0 & 0.0 & 0.0 & 0.0 & 0.1 & 0.1 & 0.1 & 0.1 \\ 10.00 & 0.0 & 0.0 & 0.0 & 0.0 & 0.0 & 0.0 & 0.1 & 0.1 & 0.1 \\ 15.00 & 0.0 & 0.0 & 0.0 & 0.0 & 0.0 & 0.0 & 0.0 & n .0 & 0.0 \\ 20.00 & 0.0 & 0.0 & 0.0 & 0.0 & 0.0 & 0.0 & 0.0 & 0.0 & 0.0 \\ 30.00 & 0.0 & 0.0 & 0.0 & 0.0 & 0.0 & 0.0 & 0.0 & 0.0 & 0.0\end{array}$

Case $27 \mathrm{~V}=500 \mathrm{gal}, \mathrm{k}=0.15, \mathrm{~K}_{\mathrm{D}}=500, \mathrm{R}=0.002, \mathrm{a}=0.40 \mathrm{ft}$

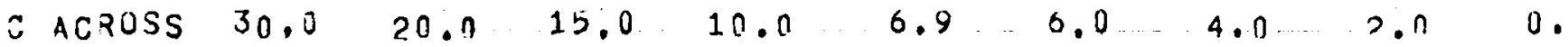

3 DONI

\begin{tabular}{|c|c|c|c|c|c|c|c|c|c|}
\hline $0: 00$ & $0: 0$ & $0: 0$ & $\begin{array}{l}0.0 \\
0.0\end{array}$ & $\begin{array}{l}0.0 \\
0.1\end{array}$ & 0.1 & 0.1 & $\begin{array}{l}0.5 \\
1.0\end{array}$ & $\begin{array}{l}3.1 \\
4.8\end{array}$ & $\begin{array}{r}107.1 \\
25.6\end{array}$ \\
\hline 2.00 & $0: 0$ & $n: n$ & 0.0 & 0.1 & 0.3 & 0.5 . & $1: 2$ & 3.9 & 8.5 \\
\hline 4.40 & 0.0 & 0,0 & 0.1 & & 0.4 & & 1.0 & 1.7 & 12 \\
\hline 5,00 & 0.0 & 0.0 & 0.1 & 0.2 & 0.4 & 0.5 & 0.9 & 1.4 & 1.7 \\
\hline $6: 95$ & 0.0 & 0.0 & 0.1 & 0.2 & $0: 4$ & 0.4 & 0.6 & $n: 9$ & 0.9 \\
\hline 00 & 0.0 & 0.0 & 0.1 & 0.2 & 0.3 & 0.4 & 0.5 & $n: 7$ & 0.7 \\
\hline 00 & 0.0 & $0 . n$ & 0.1 & n.? & 0.3 & 0.3 & 0.4 & $n \cdot 4$ & 0.5 \\
\hline & 0.0 & 0.0 & & 0.1 & & 0.2 & 0.2 & $0 . ?$ & 0.2 \\
\hline & & 0.0 & 0.1 & 0.1 & 0.1 & 0.1 & 0.1 & 0.1 & .1 \\
\hline & 0. & 0.0 & 0.0 & 0,0 & 0.1 & 0.1 & 0.1 & 0.1 & \\
\hline
\end{tabular}




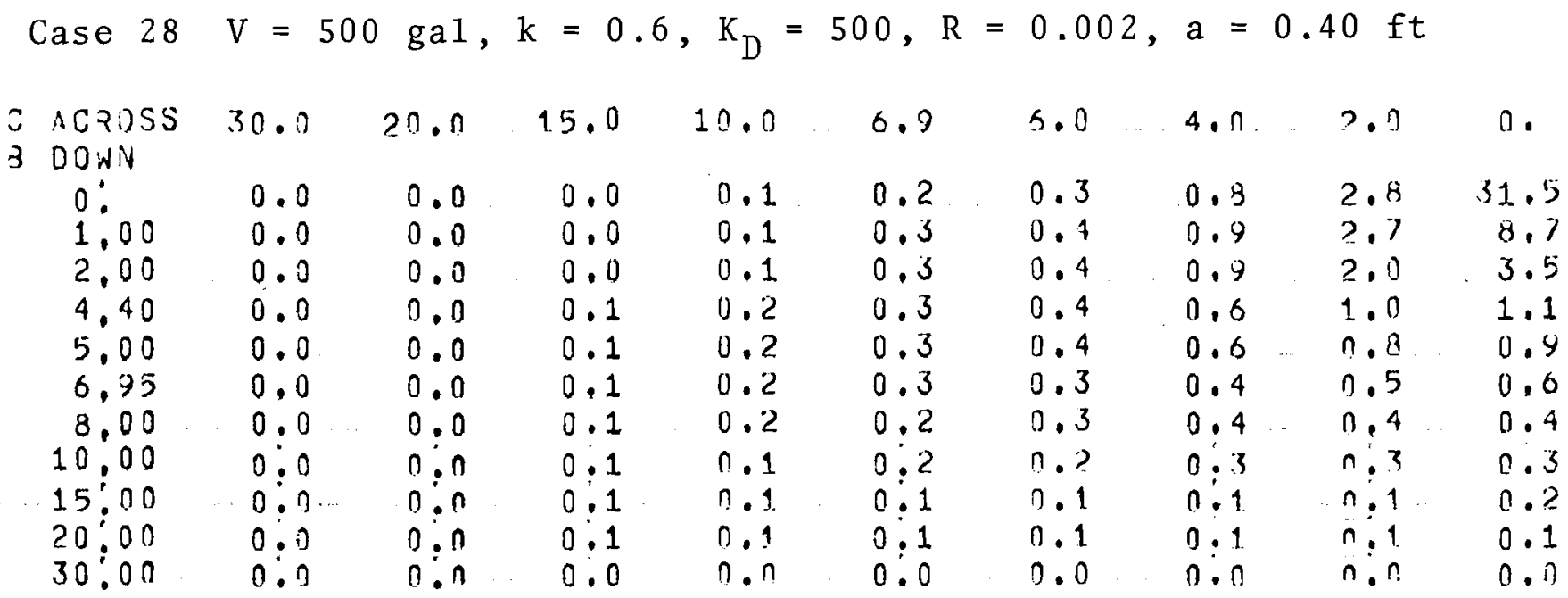

Case $29 \mathrm{~V}=1000 \mathrm{gal}, \mathrm{k}=0.15, \mathrm{~K}_{\mathrm{D}}=500, \mathrm{R}=0.002, \mathrm{a}=0.50 \mathrm{ft}$

\begin{tabular}{|c|c|c|c|c|c|c|c|c|c|}
\hline E AC:rosS & 30.0 & 20.0 & $\$ 5,0$ & $1 \cup, 0$ & 6.9 & 6,0 & 4,0 & 2.0 & 0. \\
\hline DONN & & & & & & & & & \\
\hline 0 & 0,0 & 0.0 & 0,0 &, 1 & 0,2 & 0,3 & 1,0 & 6.3 & $161 . \%$ \\
\hline $1.0 n$ & 0.0 & u. u & 0,0 & $y, ?$ & 0.3 & 0.7 & 2,1 & 10.2 & 54.2 \\
\hline 2.60 & 0.0 & Q. i & .1 & 11,3 & 0.7 & 1,0 & 2,6 & 8.2 & 17.9 \\
\hline 4,40 & 0.0 & 0.1 & 0.1 & .4 & 0.9 & 1,2 & 2,1 & 3.6 & \\
\hline 5.00 & 0,0 & 0.1 & 0,1 & 1,4 & 0.9 & 1,1 & 1,9 & 3.0 & \\
\hline 6.95 & 0,0 & $\cup .1$ & 0,2 & 4.4 & 0.0 & 0.9 & 1,5 & 1.8 & 2.0 \\
\hline 8.00 & 0,0 & $u, 1$ & 3,2 & 1) 4 & 0.7 & 0.8 & 1,1 & 1.4 & 1 . \\
\hline 10.00 & 0,0 & 0.1 & 0.2 & 0,4 & 0,0 & 0,6 & 0,8 & $n .9$ & 1.0 \\
\hline 15,00 & 0.0 & 4,1 & $0 . ?$ &, 3 & 9,3 & 0.4 & 0,4 & 0,4 & 0.2 \\
\hline 20.00 & 0.0 & 4). 1 & i) 1 & $\therefore .2$ & 0.2 & 0.2 & 0.2 & 0.3 & 0.3 \\
\hline 30.00 & 0.0 & U. 1 & .1 & 0.1 & 0.1 & 0,1 & 0,1 & 0,1 & \\
\hline
\end{tabular}

Case $30 \mathrm{~V}=1000 \mathrm{gal}, \mathrm{k}=0.6, \mathrm{~K}_{\mathrm{D}}=500, \mathrm{R}=0.002, \mathrm{a}=0.50 \mathrm{ft}$

\begin{tabular}{|c|c|c|c|c|c|c|c|c|c|}
\hline $\begin{array}{l}\text { ACROSS } \\
\text { COAN }\end{array}$ & 30.0 & 20.1 & 15,0 & 10,0 & 6.9 & 0.0 & 4,0 & 2,0 & 0. \\
\hline 0 & 0.0 & 0,0 & 0.1 & 0,2 & 0.5 & 0.7 & 1,7 & 5.6 & 49.3 \\
\hline 1.00 & 0.0 & 0.0 & 0.1 & 0,2 & 0.0 & 0.8 & 1.9 & 5.4 & 18.0 \\
\hline 2.00 & 0.0 & 0.0 & 0.1 & 4,3 & 0.7 & 0.9 & 1,8 & 4.1 & 7.2 \\
\hline 4.40 & 0,0 & 0.1 & 0.1 & 0.3 & 0.7 & 0.8 & 1,3 & 1.9 & 2.3 \\
\hline 5.00 & 0.0 & 0.1 & 0.1 & 6,3 & 0.6 & 0,8 & 1,2 & 1.7 & 1.9 \\
\hline 6.95 & 0.0 & 0.1 & 0.2 & 0.3 & 0.5 & 0.6 & $\begin{array}{l}0,8 \\
0.7\end{array}$ & 1.0 & 1.1 \\
\hline 8.00 & 0.0 & 0.1 & 0.2 & i. 3 & 0.5 & 0.6 & 0,7 & 0.8 & 0.9 \\
\hline $\begin{array}{l}10.00 \\
15.00\end{array}$ & $\begin{array}{l}0.0 \\
0.0\end{array}$ & $\begin{array}{l}0.1 \\
0.1\end{array}$ & $\begin{array}{l}0, ? \\
0,1\end{array}$ & $\begin{array}{l}0,3 \\
0,2\end{array}$ & $\begin{array}{l}0.4 \\
3.2\end{array}$ & $\begin{array}{l}0.4 \\
0.3\end{array}$ & $\begin{array}{l}0.5 \\
0.3\end{array}$ & $\begin{array}{l}0.6 \\
0.3\end{array}$ & $\begin{array}{l}0.6 \\
0.3\end{array}$ \\
\hline 20.00 & 0.0 & 0.1 & & 4,1 & 0.2 & 0.2 & 0.2 & 0.2 & 0.2 \\
\hline 30.00 & 0.0 & 0,1 & 0.1 & 6,1 & 0.1 & & 0,1 & 0.1 & 0,1 \\
\hline
\end{tabular}


BNWL-181

Case $31 \mathrm{~V}=5000 \mathrm{gal}, \mathrm{k}=0.15, \mathrm{~K}_{\mathrm{D}}=500, \mathrm{R}=0.002, \mathrm{a}=0.86 \mathrm{ft}$

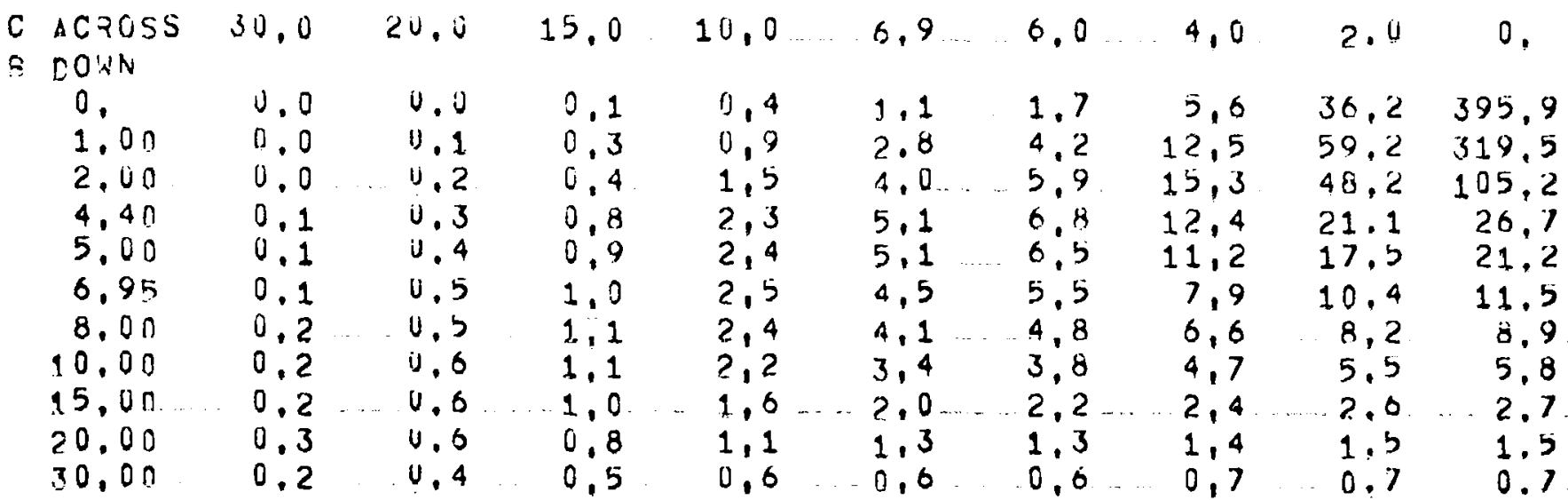

Case $32 \mathrm{~V}=5000 \mathrm{gal}, \mathrm{k}=0.6, \mathrm{~K}_{\mathrm{D}}=500, \mathrm{R}=0.002, \mathrm{a}=0.86 \mathrm{ft}$

\begin{tabular}{|c|c|c|c|c|c|c|c|c|c|}
\hline $\begin{array}{l}\text { ACROSS } \\
\text { COWN }\end{array}$ & 30,0 & 20.0 & 15,0 & 10,0 & 6.9 & 0,0 & 4,0 & 2.0 & 0 , \\
\hline 0 & 0.0 & $\cup, 1$ & 0.3 & 1,0 & 2.5 & 3,5 & 8,5 & 28.2 & 137.2 \\
\hline 1.00 & 0.1 & 0.2 & 2.4 & 1,3 & 3.1 & 4,3 & 9,8 & 28.5 & 100,0 \\
\hline 2,00 & 0.1 & 4.2 & 2,5 & 1,5 & 3.5 & 4,7 & 9,6 & 21.9 & 38.8 \\
\hline 4.40 & 0.1 & 4.3 & 0.7 & 1,8 & 3.5 & 4,3 & 6,9 & 10,3 & 12.3 \\
\hline 5.00 & 0.1 & 4.4 & 0.7 & 1,8 & 3.4 & 4,1 & 6.2 & 8.8 & 10.1 \\
\hline 6,95 & 0.1 & 0.4 & 0,8 & 1,7 & 2.9 & 3,3 & 4,5 & 5,5 & 6.0 \\
\hline 8.00 & 0.2 & $\cup .4$ & 0.8 & 1,7 & 2,6 & 2,9 & 3,8 & 4,5 & 4,8 \\
\hline 10.00 & 0.2 & 0.4 & 0,8 & 1,5 & 2,1 & 2,3 & 2,8 & 3.1 & 3.3 \\
\hline 15.00 & 0.2 & U. 4 & 0.7 & 1,0 & 1,3 & 1,4 & $-1,5$ & 1.6 & 1.0 \\
\hline 20.00 & 0.2 & 0.4 & 0.5 & 0,7 & 0.8 & 0,9 & 0,9 & 1,0 & 1.0 \\
\hline .20 .00 & 0.2 & $\cup .3$ & 0,3 & 0,4 & 0.4 & 0,4 & 0,4 & 0.5 & 0,5 \\
\hline
\end{tabular}

Case $37 \mathrm{~V}=10,000 \mathrm{gal}, \mathrm{k}=0.15, \mathrm{~K}_{\mathrm{D}}=500, \mathrm{R}=0.002, \mathrm{a}=1.08 \mathrm{ft}$

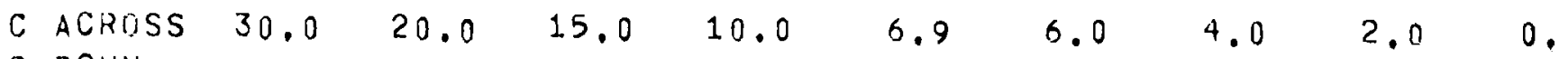
R DONN

$\begin{array}{rrrrrrrrrr}0.0 & 0.0 & 0.1 & 0.2 & 0.8 & 2.4 & 3.8 & 12.2 & 78.5 & 568.5 \\ 1.00 & 0.0 & 0.7 & 0.6 & 2.1 & 6.1 & 9.2 & 27.3 & 1.29 .3 & 679.1 \\ 2.00 & 0.1 & 0.4 & 1.0 & 3.2 & 8.8 & 12.9 & 33.3 & 105.3 & 229.2 \\ 4.40 & 0.2 & 0.8 & 1.7 & 5.0 & 11.2 & 14.8 & 27.1 & 46.1 & 58.2 \\ 5.00 & 0.2 & 0.8 & 1.9 & 5.2 & 11.1 & 14.3 & 24.4 & 38.3 & 46.2 \\ 6.95 & 0.3 & 1.7 & 2.2 & 5.4 & 9: 9 & 11.9 & 17.2 & 22.7 & 25.2 \\ 8.00 & 0.4 & 1.1 & 2.3 & 5.3 & 9: 0 & 10.6 & 14.3 & 17.9 & 19.3 \\ 10.00 & 0.4 & 1.3 & 2.4 & 4.8 & 7: 4 & 8.3 & 10.4 & 17.0 & 12.7 \\ 15.00 & 0.5 & 1.3 & 2.1 & 3.4 & 4: 4 & 4.7 & 5.3 & 5.7 & 5.8 \\ 20.00 & 0.6 & 1.2 & 1.7 & 2.4 & 2.8 & 2.9 & 3.1 & 3.3 & 3.3 \\ 30.00 & 0.5 & 0.9 & 1.1 & 1.3 & 1.4 & 1.4 & 1.5 & 1.5 & 1.5\end{array}$




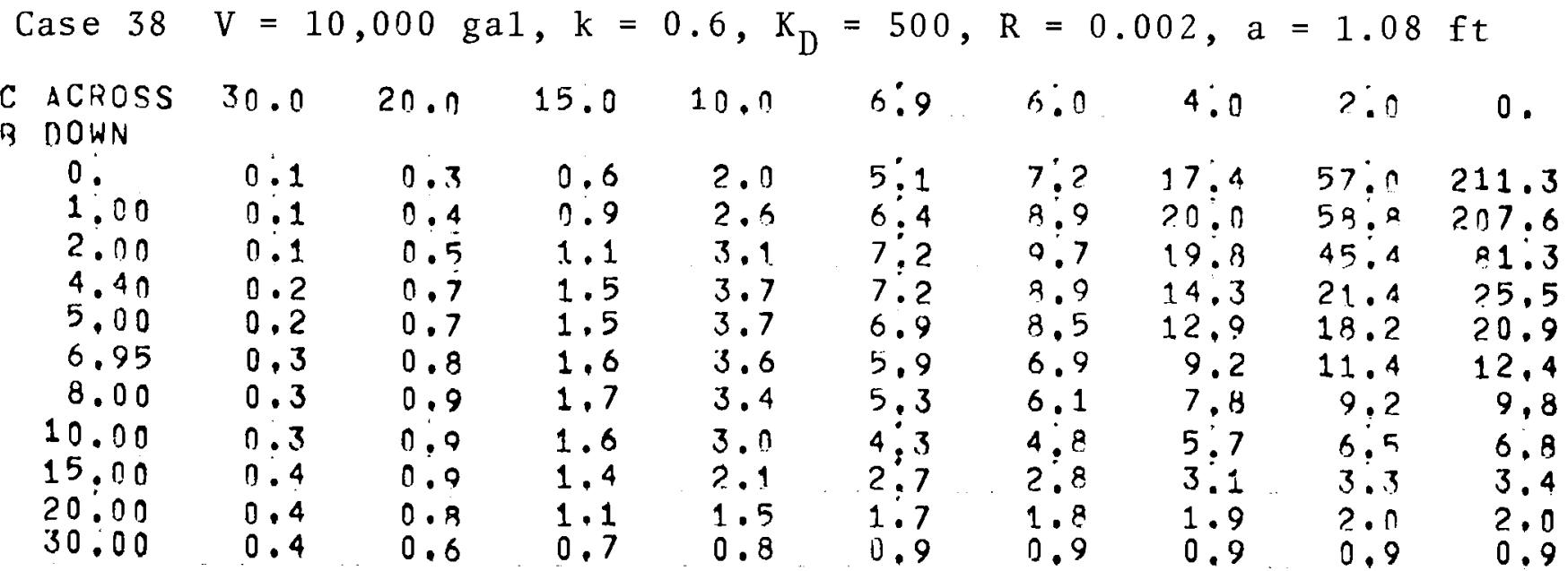

Case $33 \mathrm{~V}=25,000 \mathrm{gal}, \mathrm{k}=0.15, \mathrm{~K}_{\mathrm{D}}=500, \mathrm{R}=0.002, \mathrm{a}=1.47 \mathrm{ft}$

\begin{tabular}{|c|c|c|c|c|c|c|c|c|c|}
\hline $\begin{array}{l}\text { ACROSS } \\
\text { DOWN }\end{array}$ & 30.0 & $20 \cdot n$ & 15.0 & 10.0 & $6: 9$ & 6.0 & 4.0 & $2 . n$ & 0. \\
\hline 0 & 0.1 & 0.3 & 0.7 & 2.4 & $7: 0$ & 10.8 & $35: 1$ & 223.7 & 894.3 \\
\hline $\begin{array}{l}1.00 \\
2.00\end{array}$ & $\begin{array}{l}0.2 \\
0.3\end{array}$ & $\begin{array}{l}n \cdot 7 \\
1.2\end{array}$ & $\begin{array}{l}1.7 \\
2.8\end{array}$ & $\begin{array}{r}6.0 \\
9.3\end{array}$ & $\begin{array}{l}17: 4 \\
25: 3\end{array}$ & $\begin{array}{l}26: 4 \\
37: 1\end{array}$ & $\begin{array}{l}78: 4 \\
95: 6\end{array}$ & $\begin{array}{l}372.1 \\
301.4\end{array}$ & $\begin{array}{r}1437.1 \\
650.3\end{array}$ \\
\hline $\begin{array}{r}4.40 \\
5.00 \\
6.95 \\
8.00\end{array}$ & $\begin{array}{l}0.6 \\
0.7 \\
1.0 \\
1.1 \\
1.2\end{array}$ & $\begin{array}{l}2 . ? \\
? .4 \\
3.0 \\
3.3\end{array}$ & $\begin{array}{l}5.0 \\
5.4 \\
6.3 \\
6.6\end{array}$ & $\begin{array}{l}14.3 \\
14.9 \\
15.4 \\
15.1\end{array}$ & $\begin{array}{l}32: 1 \\
31: 8 \\
28.3 \\
25.8\end{array}$ & $\begin{array}{l}42.4 \\
41.0 \\
34.1 \\
30.3\end{array}$ & $\begin{array}{l}77: 5 \\
70.0 \\
49.3 \\
41.1\end{array}$ & $\begin{array}{r}131.9 \\
109.6 \\
64.9 \\
51.1\end{array}$ & $\begin{array}{r}166.4 \\
132.1 \\
72.0 \\
55.4 \\
36.3\end{array}$ \\
\hline 10.00 & 1.3 & 3.6 & 6.8 & 13.8 & $21: 1$ & 23.8 & 29.6 & 34.4 & 36,3 \\
\hline 15.00 & 1.6 & $3 \cdot 8$ & 6.2 & 9.9 & $42: 7$ & $13: 5$ & $15: 1$ & 16.3 & 16.7 \\
\hline $\begin{array}{l}20: 00 \\
30: 00\end{array}$ & $\begin{array}{l}1.7 \\
1.5\end{array}$ & $\begin{array}{l}3.5 \\
2.5\end{array}$ & 5.0 & 6.9 & 8.1 & 8.4 & 9.0 & 9.4 & 9.5 \\
\hline & 1,2 & $2 \cdot 2$ & 0.1 & 3,7 & 4.0 & 4.0 & 4.2 & 4.3 & $4 \cdot 3$ \\
\hline
\end{tabular}

Case $34 \mathrm{~V}=25,000 \mathrm{gal}, \mathrm{k}=0.6, \mathrm{~K}_{\mathrm{D}}=500, \mathrm{R}=0.002, \mathrm{a}=1.47 \mathrm{ft}$

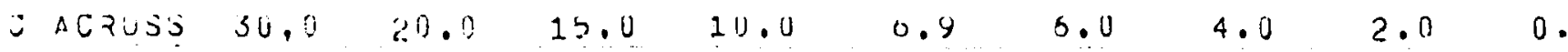
3 100 Niv

\begin{tabular}{|c|c|c|c|c|c|c|c|c|c|}
\hline 0. & 0.2 & 0.7 & $1 \cdot 1$ & 2.2 & 13.2 & 13.5 & 44.7 & 144.6 & 369.6 \\
\hline $\begin{array}{l}1.00 \\
2.00\end{array}$ & $\begin{array}{l}0.3 \\
0.4\end{array}$ & $\begin{array}{l}1.5 \\
1.3\end{array}$ & $\begin{array}{l}2.3 \\
2.8\end{array}$ & $\begin{array}{l}5.3 \\
3.2\end{array}$ & $\begin{array}{l}16.7 \\
18 . !\end{array}$ & $\begin{array}{l}23.2 \\
25.3\end{array}$ & $\begin{array}{l}52.1 \\
51.8\end{array}$ & $\begin{array}{l}155.5 \\
120.5\end{array}$ & $\begin{array}{l}444.3 \\
218.1\end{array}$ \\
\hline 4,40 & 0.0 & 1. 8 & 3.8 & 8.6 & 18.8 & 23.5 & 37.6 & 56.7 & 67.8 \\
\hline $\begin{array}{l}5.30 \\
6.95\end{array}$ & $\begin{array}{l}0.6 \\
0.6\end{array}$ & $\begin{array}{l}1.9 \\
2.2\end{array}$ & $\begin{array}{l}4.0 \\
4.3\end{array}$ & $\begin{array}{l}9.7 \\
3.3\end{array}$ & $\begin{array}{l}18.2 \\
15.3\end{array}$ & $\begin{array}{l}22.3 \\
13.1\end{array}$ & $\begin{array}{l}33.9 \\
24.3\end{array}$ & $\begin{array}{l}49.1 \\
30.2\end{array}$ & $\begin{array}{l}55.5 \\
32.8\end{array}$ \\
\hline $\begin{array}{l}8,00 \\
0,00\end{array}$ & $\begin{array}{l}0.4 \\
0.4\end{array}$ & $\begin{array}{r}2.3 \\
2.4\end{array}$ & $\begin{array}{l}4.4 \\
3.3\end{array}$ & $\begin{array}{l}5.7 \\
5.0\end{array}$ & $\begin{array}{l}14.0 \\
11.4\end{array}$ & $\begin{array}{l}13.0 \\
12.5\end{array}$ & $\begin{array}{l}20.5 \\
15.2\end{array}$ & $\begin{array}{l}24.4 \\
17.1\end{array}$ & $\begin{array}{l}26.0 \\
17.9\end{array}$ \\
\hline 0 & 1.1 & 2.4 & 0.1 & 2.0 & $\% 0$ & $7 \cdot 4$ & 8.1 & 8.7 & 8.8 \\
\hline $\begin{array}{l}.0 .00 \\
0.00\end{array}$ & $\begin{array}{l}1 \cdot 1 \\
1 \cdot 0\end{array}$ & $\begin{array}{l}2.1 \\
1.5\end{array}$ & $\begin{array}{l}3.0 \\
1.9\end{array}$ & $\begin{array}{l}4.1 \\
2.2\end{array}$ & $\begin{array}{l}4.6 \\
2.3\end{array}$ & $\begin{array}{l}4.7 \\
2.4\end{array}$ & $\begin{array}{l}5.0 \\
2.4\end{array}$ & $\begin{array}{l}5.2 \\
2.5\end{array}$ & $\begin{array}{l}5,3 \\
2,5\end{array}$ \\
\hline
\end{tabular}


Case $35 \mathrm{~V}=50,000 \mathrm{gal}, \mathrm{k}=0.15, \mathrm{~K}_{\mathrm{D}}=500, \mathrm{R}=0.002, \mathrm{a}=1.85 \mathrm{ft}$

\begin{tabular}{|c|c|c|c|c|c|c|c|c|c|}
\hline $\begin{array}{l}\text { ACROSS } \\
\text { DUWi }\end{array}$ & 30.0 & 20.0 & 15.0 & $10 \cdot ?$ & $6: 9$ & 6.0 & 4.0 & 2.0 & 0 . \\
\hline $\begin{array}{l}0.00 \\
1.00\end{array}$ & $\begin{array}{l}0.2 \\
0.4\end{array}$ & $\begin{array}{l}0.6 \\
1.6\end{array}$ & $\begin{array}{l}1.5 \\
3.9\end{array}$ & $\begin{array}{r}5.3 \\
13.5\end{array}$ & $\begin{array}{l}1.5 .8 \\
39.3\end{array}$ & $\begin{array}{l}24.5 \\
59.6\end{array}$ & $\begin{array}{r}79.5 \\
177.5\end{array}$ & $\begin{array}{l}504.9 \\
346 . ?\end{array}$ & $\begin{array}{l}1236.3 \\
2258.1\end{array}$ \\
\hline $2.0 n$ & 0.7 & 2.6 & 6.4 & $21 . n$ & $57: 2$ & 83.7 & 215.8 & $579: 2$ & 1440.8 \\
\hline 4.40 & 1. 5 & $5 . n$ & 11.3 & 32.3 & $72: 3$ & 95.5 & 174.3 & 296.2 & 373.0 \\
\hline $\begin{array}{l}5.00 \\
6.95\end{array}$ & $\begin{array}{l}1.6 \\
2.2\end{array}$ & $\begin{array}{l}5.5 \\
6.8\end{array}$ & $\begin{array}{l}12.2 \\
14.3\end{array}$ & $\begin{array}{l}33.8 \\
34.8\end{array}$ & $\begin{array}{l}71.6 \\
63.7\end{array}$ & $\begin{array}{l}92.3 \\
76.9\end{array}$ & $\begin{array}{l}157.4 \\
111.0\end{array}$ & $\begin{array}{l}? 46.1 \\
145.9\end{array}$ & $\begin{array}{l}220.2 \\
161.8\end{array}$ \\
\hline 8.00 & 2.4 & 7.4 & 15.0 & 34.0 & $58: 0$ & 68.1 & 92.4 & 114.8 & 124.4 \\
\hline $\begin{array}{l}10.00 \\
15.00\end{array}$ & $\begin{array}{l}2.9 \\
3.6\end{array}$ & $\begin{array}{l}8.5 \\
8.6\end{array}$ & $\begin{array}{l}15.4 \\
13.9\end{array}$ & $\begin{array}{l}31.1 \\
22.3\end{array}$ & $\begin{array}{l}47: 5 \\
28: 5\end{array}$ & $\begin{array}{l}53.6 \\
30.4\end{array}$ & $\begin{array}{l}66: 7 \\
34.1\end{array}$ & $\begin{array}{l}77.4 \\
36.6\end{array}$ & $\begin{array}{l}81.5 \\
37.5\end{array}$ \\
\hline 20.00 & 3.8 & 7.8 & 11.2 & 15.5 & $18^{\circ}: 2$ & $1^{8}: 9$ & 20.3 & $21: 1$ & $? 1.4$ \\
\hline 30.00 & 3.5 & 5.6 & 7.0 & 8.3 & 8.9 & 9.1 & 9.4 & 9.5 & 9.6 \\
\hline
\end{tabular}

Case $36 \mathrm{~V}=50,000 \mathrm{ga} 1, \mathrm{k}=0.6, \mathrm{~K}_{\mathrm{D}}=500, \mathrm{R}=0.002, \mathrm{a}=1.85 \mathrm{ft}$

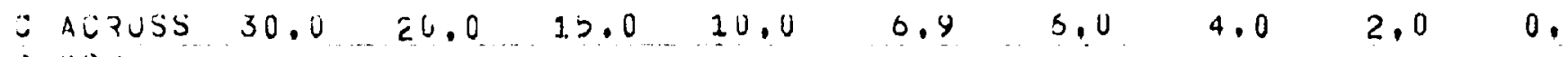

3 JUN

\begin{tabular}{|c|c|c|c|c|c|c|c|c|c|}
\hline 0. & 0.5 & 1.5 & 5.6 & 10.9 & 27.5 & 38.9 & 91,8 & 293.3 & 558.2 \\
\hline $\begin{array}{l}1.00 \\
2.00\end{array}$ & $\begin{array}{l}0.6 \\
0.0\end{array}$ & $\frac{2.1}{2.7}$ & $\begin{array}{l}4.8 \\
6.0\end{array}$ & $\begin{array}{l}14.3 \\
1 / .1\end{array}$ & $\begin{array}{l}34.8 \\
39.1\end{array}$ & $\begin{array}{l}49.3 \\
22.8\end{array}$ & $\begin{array}{l}108.4 \\
108.3\end{array}$ & $\begin{array}{l}329.8 \\
254.9\end{array}$ & $\begin{array}{l}717.4 \\
462.9\end{array}$ \\
\hline .90 & 1.2 & 3.8 & 6.0 & 20.2 & 39.4 & 49.2 & 19.1 & 119.5 & 143,1 \\
\hline .00 & 1.3 & 4.0 & 6.3 & $\angle U . S$ & 38.0 & 45.7 & $11 . \overline{4}$ & 101,3 & 117.2 \\
\hline .95 & 1.6 & 4.6 & $\overline{8} .0$ & 19.6 & 32.5 & 37.9 & 51.1 & 63,6 & 59,0 \\
\hline .00 & 1.1 & 4.3 & 9.2 & 15.8 & 29.4 & 30.5 & 43.0 & 51,3 & 54.7 \\
\hline 00 & 1.8 & 5.1 & 9.1 & 10.0 & 24.0 & 25.5 & 31.8 & 36.0 & 37.6 \\
\hline 00 & 2.2 & 5.1 & 1.0 & 11.0 & 14.7 & 15.5 & 17.1 & 18,2 & $1.8,6$ \\
\hline u 0 & 2.5 & 4.5 & 0.2 & 8.5 & 9.0 & 7.9 & 10.5 & 10.9 & 11.1 \\
\hline & 2.0 & 3.2 & 3.9 & 4.5 & $4 . y$ & 5.0 & $5 \cdot 1$ & 5.2 & 5.2 \\
\hline
\end{tabular}




\section{APPENDIX C}

\section{GULP}

Generalized Underground Leak Program 
APPENDIX C

C GULP - GENERALIZED UNDERGROUND LEAK PROGRAM

$\mathrm{C}$

C A FORTRAN-IV PROGRAM FOR THE UNIVAC- 1107

$c$

C

PROGRAM COMPUTES TEMPERATURES IN AND AROUND LEAKS OF HEAT GENERATING LIQUIDS FROM UNDERGROUND TANKS. LEAK SHAPE MAY BE OBLATE:OR PRO=LATE OR HEMISPHEROIDAL*, OR HEMISPHERICAL.

C

$C *$

INPUT DESCRIPTION

C*CARD TYPE

C*AND FORMAT FIELD CONTENT

$C^{*}$

C (12A6) 1-12 72 COLUMNS OF ALPHAMERIC DESCRIPTIVE INFORMATION

C A-CARD

ONE CARD PER CASE.

C B CARO

C(E8.0,9F7.0,II)

ONE CARO PER CASE. ONLY THE VARIAGLES BEING CHANGED C

C NEED BE ENTERED AFTER FIRST CASE • (EXCEPTION- MAP) ENTER NEGATIVE - I TO SET A VARIABLE TO ZERO IF IT WAS POSITIVE NON-ZERO IN PRECEDING CASE•

$1 \quad V=$ VOLUME OF LEAK, GALLONS.

$2 S$ = VOLUMETRIC HT GEN RATE IN ORIGINAL SOLUTION, BTU PER HR PER CUBIC FOOT.

3 D = DISTRIBUTION COEFFICIENT OF FISSION PRODUCTS (FP) ON THE SOIL. (CURIES FP IN SOIL/VOL SOIL)/(CURIES FP IN SOLN/ VOL SOLNI.

$4 E=$ FRACTION VOIDS IN SOIL.

$5 K=$ THERIVIAL COND SOIL, (BTU-FT)/(HR SQ FT DEG F)

6 KM= THERMAL COND CONCRETE, DITTO

$7 M=$ CONCRETE WALL THICKNESS, FEET

8 NUMBER OF INCREMENTS TO BE USED FOR COARSE GRID. (40 MAXIMUM). PROGRAM ASSUMES 10 INCREMENTS IF THIS FIELD IS BLANK.

9 NUMBER OF INCREMENTS TO BE USED FOR FINE GRID. (100 MAXIMUM).PROGRAM ASSUMES 40 INCREMENTS IF THIS FIELD IS BLANK.

10 ECC = ECCENTRICITY 1.0 FOR HEMISPHERE -GT - I FOR OBLATE HEMISPHEROID - LT I I FOR PROLATE. HEMISPHEROID

11 MAP = OUTPUT CONTROL VARIABLE. IF MAP IS BLANK OR ZERO,BOTH OUTPUT OPTIONS WILL BE PRINTED

-IF MAP IS I, THE B,C TEMP ARRAY WILL NOT BE PRINTED.

-IF MAP IS 2, THE TABLE OF FI,F2,F3,F4 WILL NOT BE PRINTED.

$C-C A R D$

(I 3 )

$D-C A R D$
ONE CARD PER CASE.

$1 \quad N B=$ NUMBER OF B VALUES ON D-CARDS (MAX VALUE NB=40) IF NO NEW VALUES OF B ARE TO BE ENTERED FOR THIS CASE SET NB=O AND OMIT D-CARDS •

FOUR CARDS MAX PER CASE (OMIT BLANK D-CARDSI. 


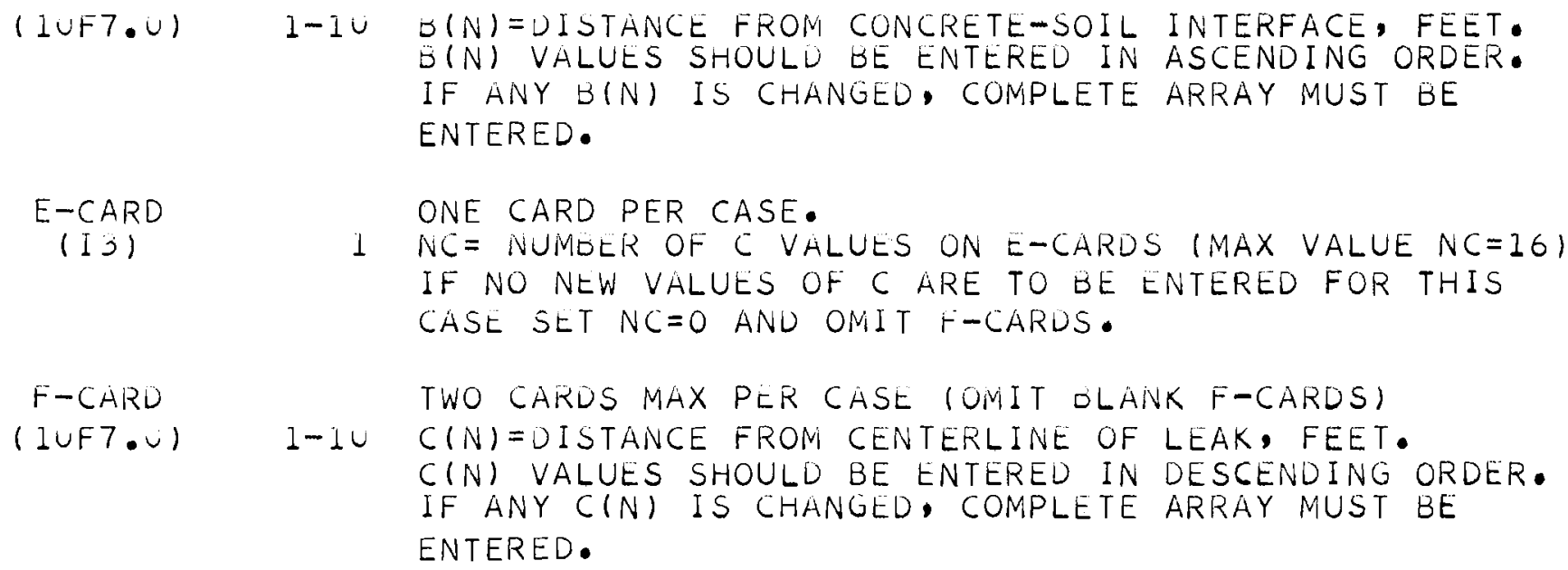

1 FORMAT(12A6)

2 FORMAT $(1 \mathrm{HI}, 12 \mathrm{A6}, 34 \mathrm{X}, 5 \mathrm{H}$ PAGE, I5/)

3 FORMAT (E8・0,9F7.0, I 1 )

4 FORMAT (I 3 )

5 FORMAT ( 1 OF 7.0$)$

6 FORMAT(IH, IUX,8HLEAK VOL, $12 H$ LEAK LENGTH, $3 X, 13 H D I S T A N C E$ FROM, $5 X$, 27HDELTA T, 4X, 3HM*K, 4X, 9HK*DELTA T, 3X, 4HF(1),6X,4HF(2),6X,4HF(3),6X 3, 4HF (4)/1H, 3UX,49HCONCRETE LEAK CTRLN UEGREES F 4--/IH, IIX,7HGALLONS, 5X, 4HFEET, 6X, 4HFEET, 6X,4HFEET, $15 X, 4 H A * K M, 5 X$, $55 H S * A * A / 1 H, 14 X, 1 H V, 8 X, 1 H A, 1 U X, 1 H B, 9 X, 1 H C, 8 X, 5 H T-T O / 11$

7 FORMAT(IH, 9X,IPE10.4,OPF9.2,2F10.2,F10.1,1P6E10.3)

8 FORMAT (IH, $27 \mathrm{HM}=$ CONCRETE THICKNESS FEET $=, F 6.1,12 X, 32 \mathrm{HK}$ SOIL BTU $2 /(H R$ SQFT DEG $F / F T)=, F 7.3,3 X, 2 O H V=L E A K$ VOLUME $(G A L)=, 1 P E 11.4 / 1 H$, $327 \mathrm{HE}=$ VOID FRACTION IN SOIL $=, 0 \mathrm{PF} 6.3,12 \mathrm{X}, 10 \mathrm{HK}$ CONCRETE, $21 \mathrm{X}, 1 \mathrm{H}=, \mathrm{F} 7$ 4.3,4X, $\angle U M A=L E A K$ RAUIUS $(F T)=, F 9.2 / 1 \mathrm{H}, 27 \mathrm{HU}=$ DISTRIBUTION COEFFICIE $5 N T=, F 9.3,9 X, 13 H R=1 /(D+E)=, F 6.3,4 X, 38 H S=H T$ GEN RT INITIAL SOLN 6BTU/HR CUFT = IPEI1.4/1H, I4HECCENTRICITY=,1PEI1.4/1)

9 FORMAT $(I H, 8 H C$ ACROSS,F6.I, I5F 7.1)

10 FORMAT $(1 \mathrm{H}, \mathrm{F} 7.2,15 \mathrm{~F} 7.1)$

11 FORMAT $(1 \mathrm{H}+, 7 \times, 15 \mathrm{~F} 7.1)$

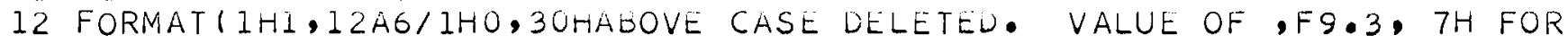
2 B (, I 2,2UH) IS NOT ACCEPTABLE. )

13 FORMAT (IH, $6 \mathrm{HB}$ DOWN $)$

14 FORMAT (1H)

15 FORMAT(IH,9X,1PEIU.4,OPF9.2,2F10.2,F10.1,1P2E10.3,4X,A6,E10.3,4X, $2 A 6, E 10.3)$

16 FORMAT(IH,2HT(,I3,IH, I3,7H) AT B=,1PE10.3,4H, C=,E10.3,4H WAS,EI 21.4,3H GY,I4,14H INTERVALS ANU,E11.4,16H (VALUE USED) BY,I4,IIHINT 3FRVALS. ,

17 FORMAT(IHL, ZIHALL TLMPS COMPUTLO BY, I4,48H INTERVAL INTEGRATION E 2XCEPT THOSE LISTED BELOW.)

INTEGER PREVNB,PREVNC

REAL TX(41), TY(41), HX(1U1), HY(101), TITLE(12),K,KM, M, MCOA, 2T $(40,16)$, DELT $(40,16), B(40), C(16), Z(10), V I(10)$, FUN $1(40,16), F U N 2(40$, $316), F U N 3(4 \cup, 16), F U N 4(40,16), K O A Q$ ARSINH $(R)=A L O G(R+S Q R T(R * 2+1 \cdot))$

CALL SETIO $(2,1)$

CALL SETIO $(3,2)$

C READ INPUT AND CALCULATE DERIVED VARIABLES 


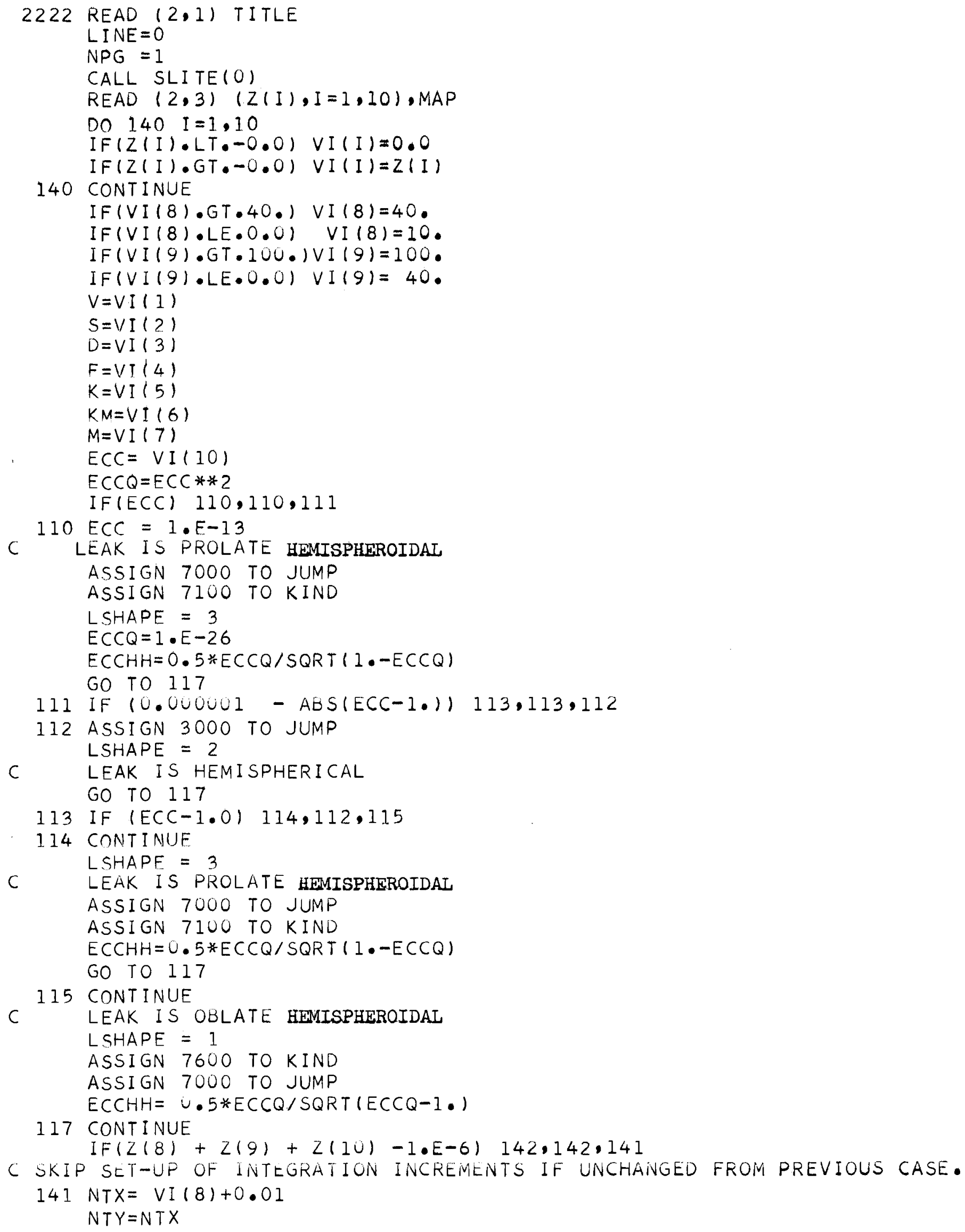




$$
\begin{aligned}
& N H X=V I(9)+0.0 I \\
& \mathrm{NHY}=\mathrm{NHX} \\
& T \cap X=1 . / V I(8) \\
& \text { TDY }=T D X * E C C \\
& T D X 02=T D X / 2 \text {. } \\
& \text { TDYO2 }=\text { TDY } / 2 \text {. } \\
& H D X=1 \cdot / V I(9) \\
& \mathrm{HDY}=\mathrm{HDX} * \mathrm{ECC} \\
& \mathrm{HDXO} 2=\mathrm{HDX} / 2 \text {. } \\
& \text { HDYOZ }=H D Y / 2 \text {. }
\end{aligned}
$$

C

C

30 CONTINUE

$T \times(1)=T D \times 02$

$T Y(1)=T D Y O ?$

DO $30 \quad I=2, N T X$

$F=I-I$

$T X(I)=F * T D X+T D X 02$

$T Y(I)=F * T D Y+T D Y O 2$

$\mathrm{HX}(1)=\mathrm{HDXO2}$

$\mathrm{HY}(1)=\mathrm{HDYO} 2$

DO $33 \quad I=2, N H X$

$F=I-1$

$H X(I)=F * H D X+H D X 02$

$H Y(I)=F * H D Y+H D Y O ?$

33 CONT I NUE

142 CONTINUE

RFAD $(2,4)$ NB

IF (NB.LE.U) GO TO 200

$\operatorname{READ}(2,5)(B(N), N=1, N B)$

$2 \cup U$ IF (NB.LE.U) NB=PREVNB

READ $(2,4) N C$

IF (NC.LE.U) GO TO 300

$\operatorname{READ}(2,5)(C(N), N=1, N C)$

300 IF (NC.LE.U) NC=PREVNC

IF (NC.GT.1) GO TO 302

$I F(C(1)-2 \cdot E-10) 301,30 I, 302$

$30 ? \mathrm{NPG}=0$

GO TO 303

$3 \cup 2$ WRITE $(3,17)$ NTX

303 CONTINUE

$R=1 \cdot /(F+D)$

$V G S=V * R / 7.481$

C STORE HT GEN RATE OF SOLN FOR OUTPUT $S L I Q=S$

C CONVERT HT GEN RATE IN SOLN TO HT GEN RT IN SOIL $S=S / R$

$A=(0.47746 * V G S / E C C Q) * 0.33333333$

$D W T=M * K /(A * K M)$

CONV $=S * A * * 2 / K$

$P R E V N B=N B$

$P R E V N C=N C$

DO $1400 \quad N N=1$, NB

$B N N=B(N N)$

IF (BNN・LE. O.) BNN=1・E-10 
C CHECK FOR INVALID B VALUE

IF (BNN + DWT) 408,408,412

408 WRITE $(3,12)$ TITLE, BNN, NN

GO TO 2222

$412 B O A=B N N / A$

$B O A Q=B O A * 2$

$O D B A L L=B O A+2 \cdot * D W T$

DO $1300 \mathrm{JJ}=1, \mathrm{NC}$

$C J J=C(J J)$

IF (CJJ-2.E-10) $460,480,480$

460 CONTINUE

$B E T A=B N N+M * K / K M$

$B E T O A=B E T A / A$

$B E T O A Q=B E T O A * 2$

CALL CLINE (BETOA, BETOAQ,BOA,BOAQ, OMEGA,PSII, PSI 2 , LSHAPE, ECC,

$2 E C(Q, B N N, A)$

FUNI $(N N, J J)=6 H P S I I=$

$F(J N 2(N N, J J)=P S I 1$

FUN3 $(N N, J J)=6$ HPSI $2=$

FUN4 $(N N, J J)=P S I 2$

$T(N N, J J)=-0.0$

IF (PSI2-PSII) $6200,6400,6400$

C62UU IS ROUTE FOR A POINT INSIDE OF LEAK. 6400 IF FOR POINT OUTSIDE.

6200 DELT $(N N, J J)=\operatorname{CONV*} 0.25 *(P S I 1-O M E G A)$

GO TO 1300

$6400 D E L T(N N, J J)=$ CONV* $0.25 *(P S I 2-O M E G A)$

GO TO 1300

$480 \mathrm{COA}=\mathrm{CJJ} / \mathrm{A}$

$C O A Q=C O A * 2$

$R O A Q=B O A Q+C O A Q / E C C Q$

$R O A=S Q R T(R O A Q)$

$B E T A=B O A Q+C O A Q-E C C Q-1$.

$B E T A Q=B E T A * 2$

GAMMA $=C O A Q+E C C Q *(B O A Q-1$.

$M C O A=-C O A$

GO TO JUMP, $(30 \cup 0,7000)$

3000 IF $(R O A-1) \quad 410,410,$.

410 PSIROA $=0.33333333+0.16666667 *(1 \cdot-R O A * 21$

GO TO 420

405 PSIROA $=U .33333333 / R O A$

GO TO 420

7000 IF (ROAQ- - . $) 7005,7005,7010$

C7UUS POINT OF INTEREST IS INTERNAL POINT

$7005 \mathrm{KOAQ}=0.0$

GO TO 7050

7010 SIGNOR = SIGN(I,,BETA)

KOAQ $=U \cdot 5 * \forall E T A *(1 \bullet+5 I G N O R * S Q R T(1 \bullet+4 \bullet * G A M M A / B E T A Q))$

CTUIU POINT OF INTEREST IS EXTERNAL POINT

7050 GO TO KIND, $(7100,7600)$

$76 \cup 0 \mathrm{FTI}=E C C H H *(1 .-1 \quad C O A Q-2 \cdot * B O A Q) /(2 \cdot *(E C C Q-1 \cdot 1))$

$A N G=S Q R T((E C C Q-1 \cdot) /(E C C Q+K O A Q))$

$F T 2=A S I N(A N G)$

$F T 3=(.25 * E C C Q * S Q R T(1 .+K O A Q) /(E C C Q-1 \cdot)) * C O A Q /(E C C Q+K O A Q)$

$F T 4=U .5 * E C C Q * 3 O A Q /((E C C Q-1 \bullet) *(S Q R T(1 \bullet+K O A Q)))$

PSIROA $=F T I * F T 2+F T 3-F T 4$ 


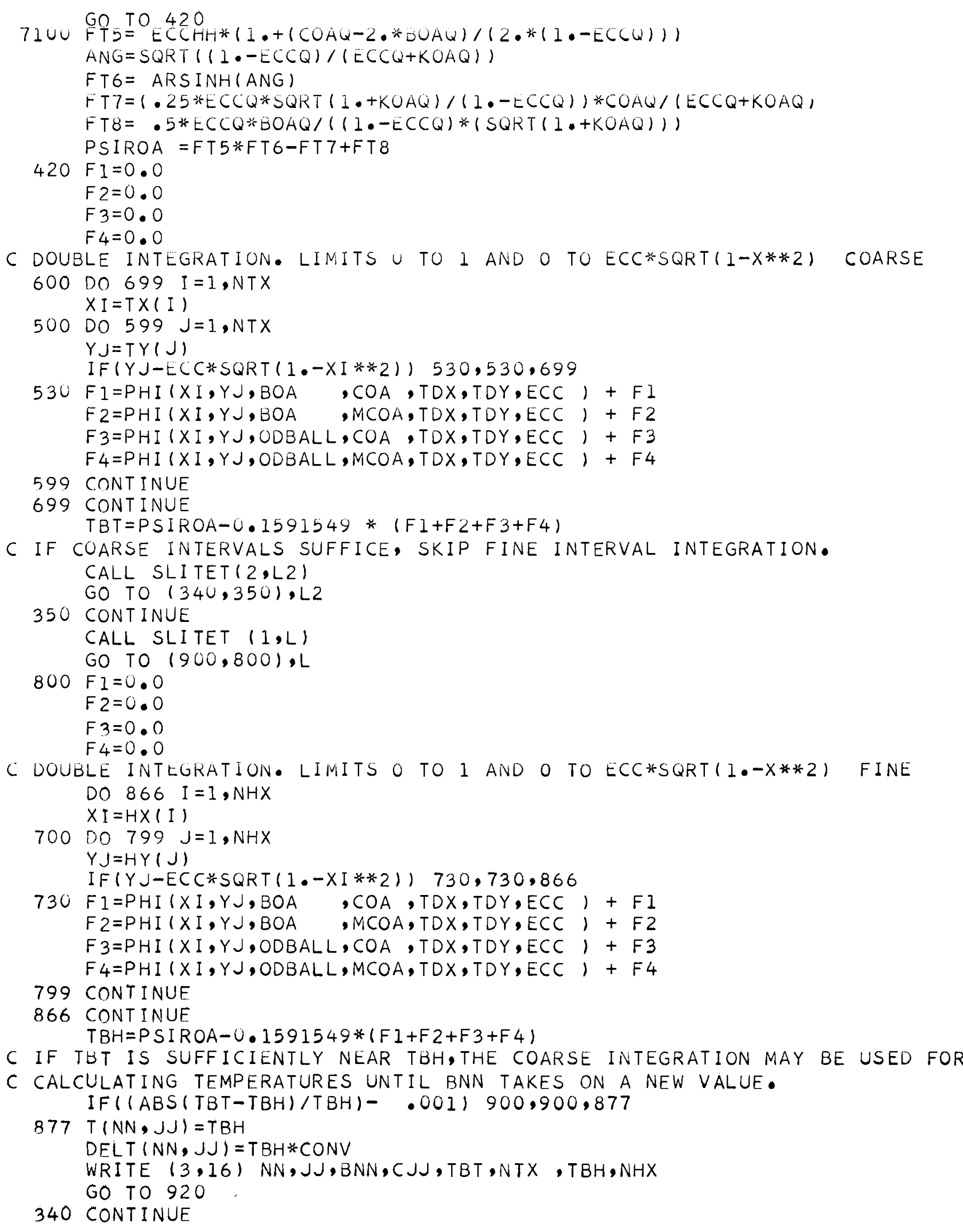


341 CALL SLITE(2)

C TURN SENSELIGHT I 900 CALL SLITE(I)

$T(N N, J J)=T B T$

$\operatorname{DELT}(N N, J J)=T(N N, J J) * C O N V$

C TURN SENSELIGHT 2 ON TO SKIP FINE INTEGRATION FOR REMAINING BNNS. IF ( JJ-I) $910,910,920$

910 CALL SLITE(2)

920 CONTINUE

C DO NOT STORE FUNCTIONS IF NOT REQUIRED FOR OUTPUT. IF (MAP.EQ.1) GO TO 1300

FUNI $(N N, J J)=F 1$

FUN2 $(N N, J J)=F 2$

$F U N 3(N N, J J)=F 3$

$F \cup N 4(N N, J J)=F 4$

1300 CONTINUE

1400 CONT INUE

$L I N E=55$

IF (MAP.GT.1) GO TO 4000

2000 DO $2700 \mathrm{~KB}=1$, NB

DO $2500 \quad K C=1, N C$

IF (LINE.LE.38) GO TO 2300

$N P G=N P G+1$

WRITE $(3,2)$ TITLE,NPG

WRITE $(3,8) M, K, V, E, K M, A, D, R, S L I Q, E C C$

WRITE $(3,6)$

LINE $=12$

C PRINT COLUMN OUTPUT AND FUNCTION TABLE

2300 CONTINUE

IF $(C(K C)-2 \cdot E-10) 2350,2350,2370$

2350 WRITE $(3,15) \quad V, A, B(K B), C(K C), D E L T(K B, K C), D W T, T(K B, K C), F U N I(K B, K C)$, $2 F U N 2(K B, K C), F \cup N 3(K B, K C), F \cup N 4(K B, K C)$

LINE $=L I N E+1$

GO TO 2500

2370 WRITE $(3,7) \mathrm{V}, A, B(K B), C(K C), D E L T(K B, K C), D W T, T(K B, K C), F U N 1(K B, K C)$, $2 F \cup N 2(K B, K C), F \cup N 3(K B, K C), F \cup N 4(K B, K C)$

2500 CONTINUE

WRITE $(3,14)$

LINE $=$ LINE + 1

2700 CONTINUE

4000 LINE $=55$

IF (MAP-1) 4100,5000,4100

$C$ PRINT TEMPERATURES IN $B$ BY $C$ ARRAY

$4100 \mathrm{NPG}=\mathrm{NPG}+1$

WRITE $(3,2)$ TITLE,NPG

WRITE $(3,8) \quad M, K, V, E, K M, A, D, R, S I I Q, E C C$

WRITE $(3,9)(\mathrm{C})$ I $), I=1, N C)$

WRITE $(3,13)$

DO $4200 \mathrm{~KB}=1, \mathrm{NB}$

4200 CONTINUE

WRITE $(3,10) B(K B),(D E L T(K B, K C), K C=1, N C)$

5000 GO TO 2222

FND 
SUBROUTINE CLINE (BETOA,BETOAQ,BOA,BOAQ, OMEGA, PSI I, PSI 2 , LSHAPE, $2 E C C, E C C Q, B \quad, A)$

GO TO $(1000,2000,30001$, LSHAPE

1000 CONT INUE

C

$O T I=B E T O A *(B E T O A+1 \bullet) /(1 \bullet-E C C Q)$

SHAPE IS OBLATE

$O T 2=B E T O A * S Q R T(E C C Q+B E T O A Q) /(1 \bullet-E C C Q)$

$O T 3=(E C C Q-B E T O A Q * E C C Q /(1 \bullet-E C C Q)) / S Q R T(E C C Q-1 \bullet)$

$D E N O=S Q R T(B E T O A Q+(E C C Q-1 \cdot) *(E C C Q+B E T O A Q))$

$S A 1=(-B E T O A) / D E N O$

$S A 2=(1 \cdot-E C C Q+B E T O A) / D E N O$

OMEGA $=$ OT 1-OT2-BETOA-OT3*(ASIN(SA1)+ASIN(SA2))

C S.R. WILL RETURN A VALUE OF O.O FOR PSI 2 IF POINT IS INSIDE OF LEAK PSI $2=0.0$

TIPI $=B O A-2 * * B O A Q-B O A *(1 .-B O A) /(1 \cdot-E C C Q)+B O A * S Q R T(E C C Q$

$2+B O A Q) /(1 \cdot-F C C Q)$

$T 2 P 1=(E C C Q+B O A Q *(E C C Q /(E C C Q-1 \cdot))) / S Q R T(E C C Q-1 \bullet)$

$D E N O=S Q R T(B O A Q+(E C C Q-1) *.(E C C Q+B O A Q))$

PSII $=$ TIPI + T2PI*(ASIN(-BOA/DENO) - ASIN( (1.-ECCQ-BOA)/DENO)

IF $(B-A) \quad 1200,1400,1400$

1200 RFTURN

C RETURN TO MAIN PROGRAM IF POINT IS INSIDE OF LEAK

$C$ CONTINUE IF POINT IS OUTSIDE OF LEAK

1400 CONTINUE

$Z 1 P I=(-B O A)-B O A *(B O A-1 \cdot) /(1 \cdot-E C C Q)+B O A * S Q R T(E C C Q+B O A Q) /(1 .-E C C Q)$

PSI $2=P S I 1-T I P I+Z I P I$

RFTIJRN

2000 CONTINUE

C

TUMP $=(1 \cdot+B O A Q) * 1 \cdot 5$

TUMO $=(1 \cdot+B E T O A Q) * 1.5$

OMEGA $=1 \bullet+\cup \cdot 66666667 * B E T O A Q-(T U M O-1 \bullet) / B E T O A / 1.5$

PSI $2=0.0$

C S.R. WILL RETURN A VALUE OF 0.0 FOR PSI 2 IF POINT IS INSIDE OF LEAK

PSI $1=1 .-1.3333333 * B O A Q+(T U M P-1 \bullet) / B O A / 1.5$

IF $(B-A) \quad 2200,2400,2400$

2200 RETURN

C RETURN TO MIAIN PROGRAM IF POINT IS INSIDE LEAK

2400 CONTINUE

PSI $2=(-I \cdot)-U \cdot 66666667 * B O A Q+(T U M P+1 \cdot) / B O A / 1 \cdot 5$

RFTURN

3000 CONTINUE

C

$O T 1=B E T O A *(B E T O A+1 \cdot 1 / 11 \cdot-E C C Q)$

$O T 2=B E T O A * S Q R T(E C C Q+\bar{D} E T O A Q) /(1 \bullet-E C C Q)$

$O T 3=(E C C Q-B E T O A Q *(E C C Q /(1 .-E C C Q))) / S Q R T(1 .-E C C Q)$

$T O P=B E T O A+1 \bullet-E C C Q+(1 \bullet+B E T O A) * S Q R T(1 \bullet-E C C Q)$

$B O T=B E T O A+S Q R T((I \bullet-E C C Q) *(E C C Q+B E T O A Q))$

$O T 4=A L O G(T O P / B O T)$

OMEGA $=O T 1-O T 2-B E T O A+O T 3 * 0 T 4$

C S.R. WILL RETURN A VALUE OF 0.0 FOR PSIZ IF POINT IS INSIDE LEAK 
PSI $=82=80 \AA-2 \cdot * B O A Q-B O A *(1 .-B O A) /(1 \cdot-E C C Q)+B O A * S Q R T(E C C Q$ $2+B O A Q) /(1 \cdot-E C C Q)$

$T 2 P 2=(E C C Q-B O A Q *(E C C Q /(1,-E C C Q))) / S Q R T(1,-E C C Q)$

TOP2 $=1 \bullet-E C C Q-B O A+(1 .-B O A) * S Q R T(1 \cdot-E C C Q)$

$B O T 2=(-B O A)+5 Q R T((1 \bullet-E C C Q) *(E C C Q+B O A Q))$

IF (ABS (T2P2+TOP2+BOT2)-1.E-6) 3101,3101,3121

3101 PSII $=$ TIP2

GO TO 3191

3121 PSII = TIP 2+T2P 2*ALOG (TOP2/BOT 2$)$

3191 CONTINUE

I $F(B-A) \quad 3200,3400,3400$

3200 RETURN

C RETURN TO MAIN PROGRAM IF POINT IS INSIDE OF LEAK

$3400 Z 1 P 2=(-B O A)-B O A *(B O A-1 \cdot) /(1 .-E C C Q)+B O A * S Q R T(E C C Q+B O A Q) /(1 .-E C C Q)$ $Z O P 2=1 .-E C C Q-B O A-(1 .-B O A) * S Q R T(1 .-E C C Q)$

$P S I 2=Z 1 P 2+T 2 P 2 * A L O G(Z O P 2 / B O T 2)$

RETURN

FND 
FUNCTION PHI $(X, Y, B, C, D E L X, D E L Y, E C C)$

$E C C Q=E C C * * 2$

$T 1=E C C * S Q R T(1 .-X * * 2-Y * * 2 / E C C Q)$

$T 2=S Q R T((X+B) * * 2+(Y-C) * * 2+E C C * E C C *(1 \cdot-X * * 2-Y * * 2 / E C C Q))$

$T 3=S Q R T((X+B) * * 2+(Y-C) * 2)$

$P H I=D E L X * D E L Y * A L O G((T)+T 2) / T 3)$

RETURN

END

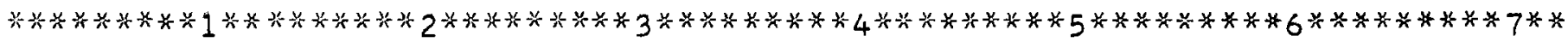
EX A M P L E I N P U T F O R G U L P F O L L O W

TEST CASE FOR GENERALIZED UNDERGROUND LEAK PROGRAM - ECCENTRICITY $=1.0$
$5 \cdot E+U 3$
.6
.35
0.15
0.5
2.0
40 .
40.
1.0

11

U.

30.

1.

9

30.

2.

4. 45 .

6.95

8.

10

15.

20.

20.

15. 10 . 8 .

TEST CASE FOR GULP ECCENTRICITY $=1.2$

$1 \cdot 2$

blank card

blank card

TEST CASE FOR GULP ECC $=2.00$

blank card

blank card 


\section{NOMENCLATURE}

a Depth of penetration of leak into soil or leak length, $\mathrm{ft}$. It is the radius of a hemispherical leak or the penetration along the axis of symmetry of a hemispherical leak.

$$
a=\left(3 V R / 2 \pi \varepsilon^{2}\right)^{1 / 3}
$$

b Distance from tank wall, ft

c Distance from axis of symmetry of leak measured parallel to the tank wall, ft

E Void fraction in the soil, 0.35

k Thermal conductivity of the soil, Btu/(hr) $\left(f t^{2}\right)\left({ }^{\circ} \mathrm{F} / \mathrm{ft}\right)$

$\mathrm{k}_{\mathrm{m}} \quad$ Thermal conductivity of the concrete tank liner, $0.5 \mathrm{Btu} /(\mathrm{hr})\left(\mathrm{ft} \mathrm{t}^{2}\right)\left({ }^{\circ} \mathrm{F} / \mathrm{ft}\right)$

$\mathrm{K}_{\mathrm{D}} \quad$ Volumetric fission product distribution coefficient on the soil, ( $\mathrm{Ci} / \mathrm{ft}^{3}$ of soil)/(Ci/ft ${ }^{3}$ of solution)

$\mathrm{m} \quad$ Thickness of the concrete tank liner, $2 \mathrm{ft}$

$R=\frac{1}{E+K_{D}} \begin{aligned} & \text { Ratio of final volume of the leak to the initial volume } \\ & \text { of leaking solution }\end{aligned}$

$S=S^{\prime} R$ Volumetric heat generation rate, $B t u /(h r)\left(\mathrm{ft}^{3}\right.$ of final volume of soil occupied by the leak)

$S^{\prime} \quad$ Volumetric heat generation rate, $B t u /(h r)\left(\mathrm{ft}^{3}\right.$ of solution before leakage)

$\mathrm{T}-\mathrm{T}_{\mathrm{O}} \quad$ Temperature rise caused by the $1 \mathrm{eak},{ }^{\circ} \mathrm{F}$ above the undisturbed temperature profile around the tank

V Volume of the initial solution leaked, gal

$x, y, z$ Relative position coordinates of the heat generating element in the leak volume, dimensionless 
$b+m k / k_{m}$, axial distance from mirror image of leak, ft

$\Lambda \quad$ Temperature field around a volumetrically uniform heat generating spheroid in an infinite medium, ${ }^{\circ} \mathrm{F}$

$\varepsilon$ Eccentricity of a spheroid, or the ratio of the radius of the leak at the tank wall to the penetration depth into the soil

Temperature field around a volumetrically uniform heat generating octant of a spheroid in an infinite medium, dimensionless

$k / a^{2} \quad$ A factor in the equation for temperature fields outside of spheroids

$\psi_{1} \quad$ Temperature along the axis of a volumetrically uniform heat-generating hemispheriod in an infinite medium, inside the hemispheroid, dimensionless

$\psi_{2} \quad$ Same as $\psi_{1}$ except out the rounded end of the hemispheroid Temperature along the axis of a volumetrically uniform heat generating hemispheroid in an infinite medium, out the flat end, dimensionless 


\section{$\underline{\text { REFERENCES }}$}

1. M. W. Cook and J. M. Gerhart, Waste Tank Temperature Studies, SECRET, HW-47087, January 28, 1957.

2. M. W. Cook, The Design and Application of a Heat Transfer Analogue for Radially Symmetric Problems, HW-47088, January 30,1957 .

3. W. E. Willingham and G. Jansen, Jr., Heat Transfer from Solidified Wastes in Underground Storage Tanks, BNWL-262, 1966 .

4. G. Jansen, Jr., Therma1 Consequences of Leaks in Radioactive Waste Storage Tanks, HW-80848, March 2, 1964.

5. "Soil Thermal Characteristics in Relation to Underground Power Cables," Report of the American Institute of Electric Engineers Committee on Insulated Conductors, R. W. Burre11, Chairman. Power and Apparatus, Trans. AIEE, vo1 8 , pp. 792-856, December 1960 .

6. K. C. Kno11, Unpublished Data, Pacific Northwest Laboratory, Battelle Memorial Institute, 1965.

7. W. D. MacMillan, The Theory of the Potential, pp. 24-94, McGraw Hill Book Co., New York, 1930. 


\section{ONSITE DISTRIBUTION}

Copy Number

Isochem Inc.

$\begin{aligned} 1 & \text { S. J. Beard } \\ 2 & \text { D. J. Brown } \\ 3 & \text { J. B. Fecht } \\ 4 & \text { M. K. Harmon } \\ 5 & \text { W. M. Harty } \\ 6 & \text { O. F. Hill } \\ 7 & \text { G. R. Kiel } \\ 8 & \text { R. W. McCullugh } \\ 9 & \text { H. C. Rathvon } \\ 10 & \text { H. P. Shaw } \\ 11 & \text { J. J. Shefcik } \\ 12 & \text { R. J. Sloat } \\ 13 & \text { O. V. Smiset } \\ 14 & \text { R. E. Tomlinson } \\ 15 & \text { L. L. Zahn } \\ 16 & \text { Isochem File Copy } \\ & \\ & \text { Pacific Northwest Laboratory }\end{aligned}$

\begin{tabular}{|c|c|c|}
\hline 17 & & G. J. Alkire \\
\hline 18 & & J. M. Atwood \\
\hline 19 & & R. E. Burns \\
\hline 20 & & C. R. Cooley \\
\hline 21 & & G. M. Dalen \\
\hline 22 & & R. Y. Dean \\
\hline 23 & -27 & W. V. DeMier \\
\hline 28 & & A. G. Gibbs \\
\hline 29 & & W. A. Haney \\
\hline 30 & & E. R. Irish \\
\hline 31 & -40 & G. Jansen \\
\hline 41 & & B. M. Johnson \\
\hline 42 & & L. G. King \\
\hline 43 & & R.W. Nelson \\
\hline 44 & & D. W. Pearce \\
\hline 45 & & A. M. Platt \\
\hline 46 & & W. H. Swift \\
\hline 47 & & E. E. Voil and \\
\hline 48 & & M. T. Walling \\
\hline 49 & -58 & W. E. Willingham \\
\hline 59 & -63 & Technical Information Files \\
\hline 64 & -65 & Technical Publications \\
\hline
\end{tabular}




\section{ONSITE DISTRIBUTION (Contd)}

\section{Copy Number}

\section{R. K. Sharp}

67 Technical Information Library

OFFSITE DISTRIBUTION

68 R. L. Bradshaw - ORNL 
*

, 